\title{
Estimating Well Costs For Enhanced Geothermal System Applications
}

K. K. Bloomfield

P. T. Laney

August 2005

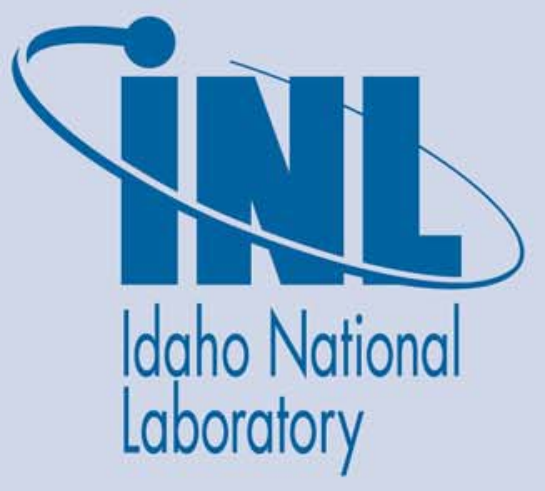

The INL is a U.S. Department of Energy National Laboratory operated by Battelle Energy Alliance 



\title{
Estimating Well Costs for Enhanced Geothermal System Applications
}

\author{
K. K. Bloomfield \\ P. T. Laney
}

August 2005

\begin{abstract}
Idaho National Laboratory
Renewable Energy and Power Technologies

Idaho Falls, Idaho 83415
\end{abstract}

Prepared for the

U.S. Department of Energy

Assistant Secretary for Energy Efficiency and Renewable Energy Idaho Operations Office

Contract DE-AC07-05ID14517 


\begin{abstract}
The objective of this work reported is to investigate the costs of drilling and completing wells and to relate those costs to the economic viability of enhanced geothermal systems (EGS). This is part of a larger parametric study of major cost components in an EGS. The possibility of improving the economics of EGS can be determined by analyzing the major cost components of the system, which include well drilling and completion. Determining the sensitivity of EGS cost components will help to identify areas of research to reduce those costs. The results of this well cost analysis will help quantify well development cost for EGS.
\end{abstract}




\section{ACKNOWLEDGEMENT}

This work was supported by the U.S. Department of Energy, Assistant Secretary for Energy Efficiency and Renewable Energy under DOE Idaho Operations Office Contract DE-AC07-05ID14517. Such support does not constitute any endorsement by the U.S. Department of Energy of the views expressed in this publication. 


\section{CONTENTS}

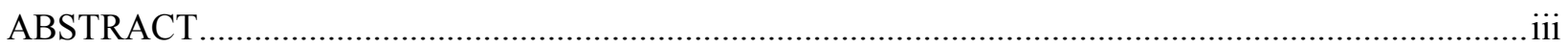

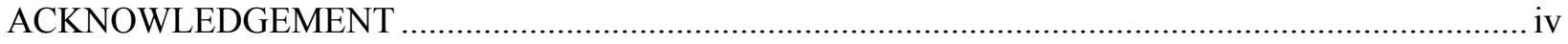

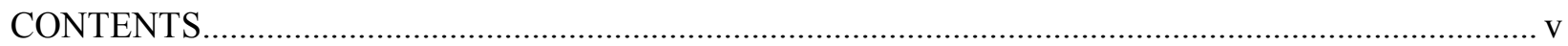

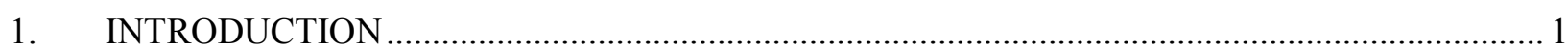

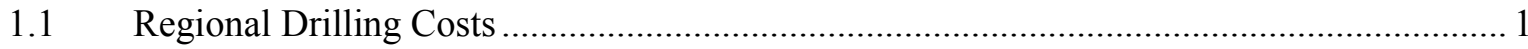

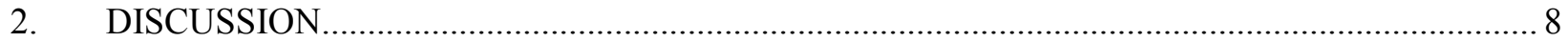

3. $\quad$ PLOTS

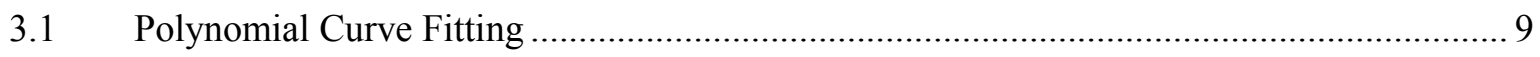

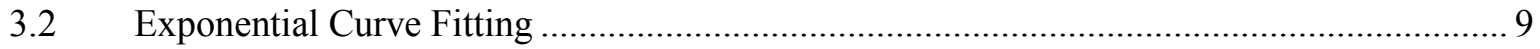

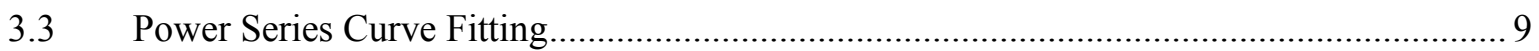

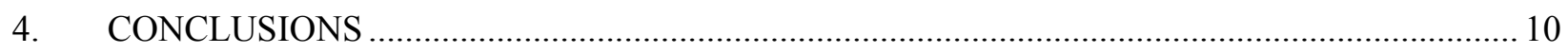

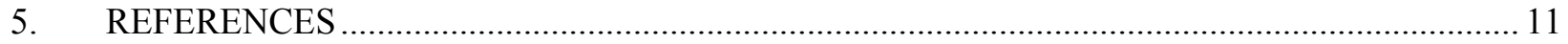

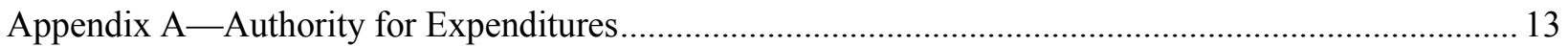

Appendix B —-Drilling Costs versus Depth Curves ..................................................................... 41

\section{FIGURES}

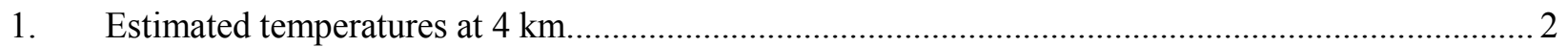

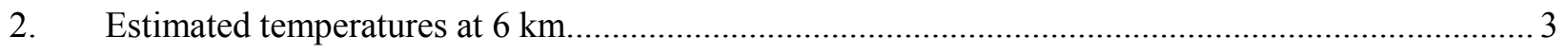

3. Average depth versus median cost of Table 1, geothermal wells in Central America and the

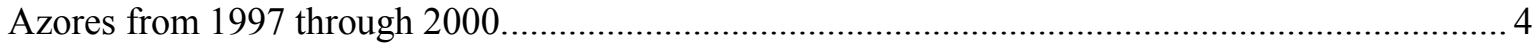

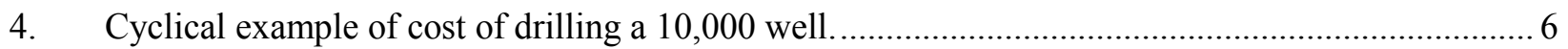

\section{TABLES}

1. Drilling costs from 1997 to 2000 for Central America and the Azores.......................................... 4

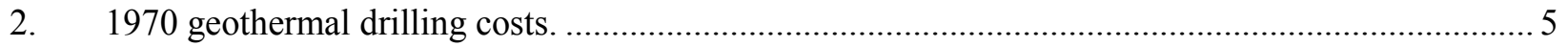

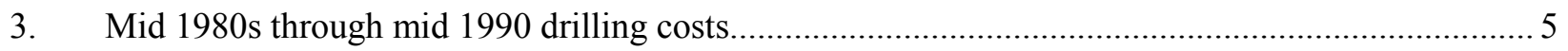




\section{Estimating Well Costs for Enhanced Geothermal System Applications \\ 1. INTRODUCTION}

Enhanced geothermal system (EGS) reservoir performance is controlled by the interplay of a complex set of parameters: reservoir, geologic, drilling, well completion, plant design, and operation. In order to identify, analyze, and mitigate the economic risks of any EGS prospect, one must first understand the relative importance of each of these parameters, how its relative importance changes under different constraints, and how they interactively affect EGS production. To date, no comprehensive parametric study on EGS is known to have been conducted within the industry. U.S. industry has not conducted a comprehensive study because it considers EGS an emerging technology. The parametric studies reported in the literature have only considered a limited set and range of parameters, thus potentially skewing their results.

To better understand EGS economics, the U.S. Department of Energy (DOE) has commissioned the Idaho National Laboratory to conduct a parametric study of EGS's major cost components and establish a baseline of information relating to EGS development costs. The drilling study reported in this document is part of that overall parametric study, undertaken to determine the relationship between available energy at depth (temperature gradient, flow rate and energy conversion efficiency), and energy costs with depth (drilling and pumping costs).

The amount of work that can be extracted from a geothermal fluid and the rate at which this work is converted to power increase as the fluid's temperature increases. The relationships between temperature and work (ideal or actual) illustrate the preference for higher fluid temperatures. Since drilling costs per foot generally increase with depth, and temperature gradients are at best linear with depth (if not slightly decreasing), it is apparent that at some depth the increase in temperature does not warrant increased drilling costs. Drilling cost results published to date are based on assumed relationships between drilling costs and depth that have no statistical basis and only illustrate the impact that drilling costs will have on the ability to access higher-temperature EGS resources. This indicates the need to know the precise relationship between drilling costs and depth. Once that relationship is established, a more realistic evaluation can be made one that incorporates these costs. Because pumping costs from increased lift and greater frictional loss with length of wellbore increase with depth, and parasitic load impacts power generation potential as well, all must be included in a study of comprehensive cost of EGS power versus depth.

Our first goal is to assemble reasonable drilling-costs-with-depth formulae for various regions of the United States and couple them with energy-recovery-with-depth as they relate to regional temperature gradients. Additional controls on the economic depth relationship will be the selling price of energy produced and the flow rate of each well. Obviously, higher gradient areas and areas with relatively low drilling costs have greater interest.

\subsection{Regional Drilling Costs}

To determine the areas from which to collect historical drilling costs, we used the nation-wide 4- and 6-km temperature gradient data developed by the Southern Methodist University Geothermal Laboratory and maps prepared by Idaho National Laboratory (Figures 1 and 2). 


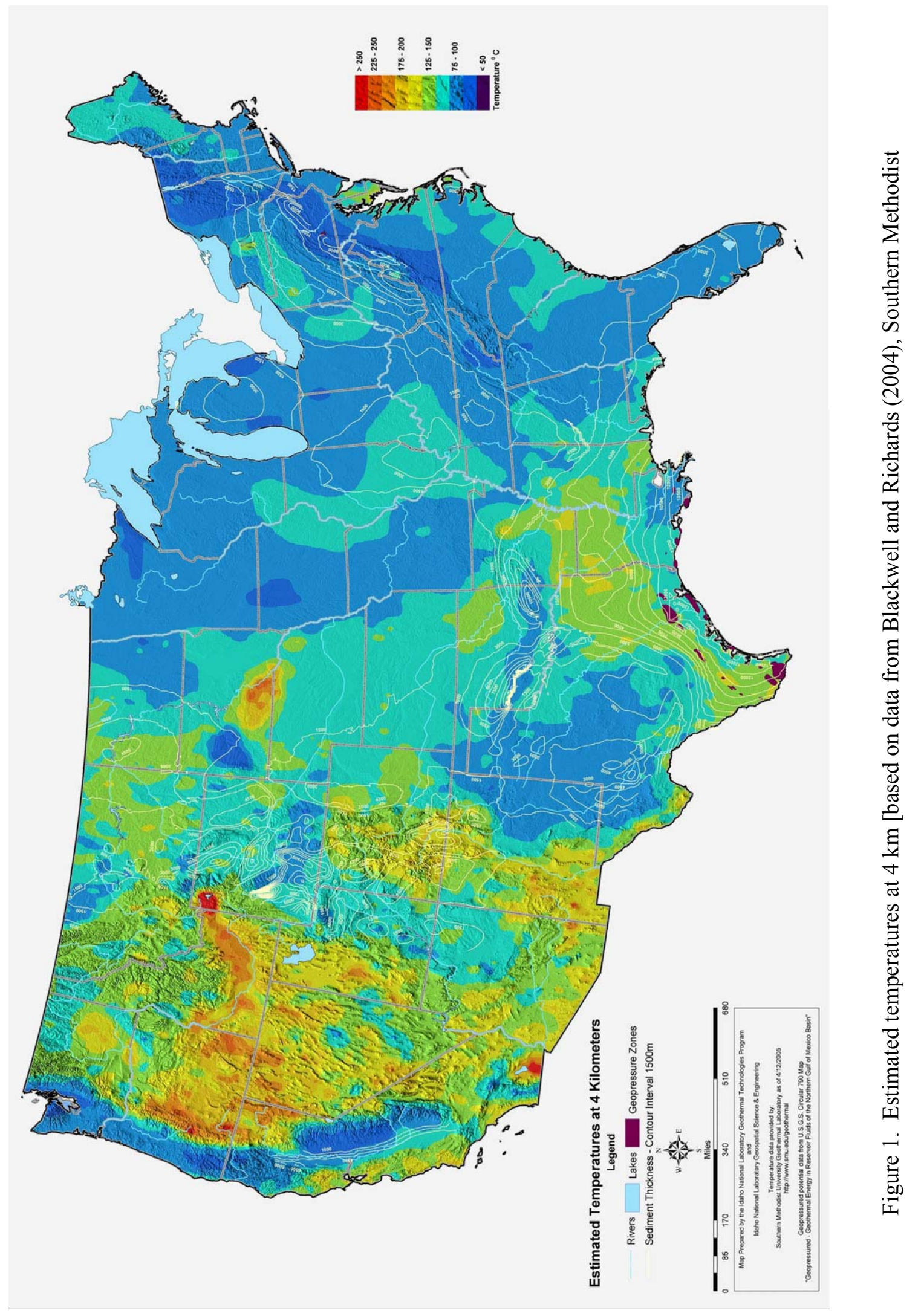




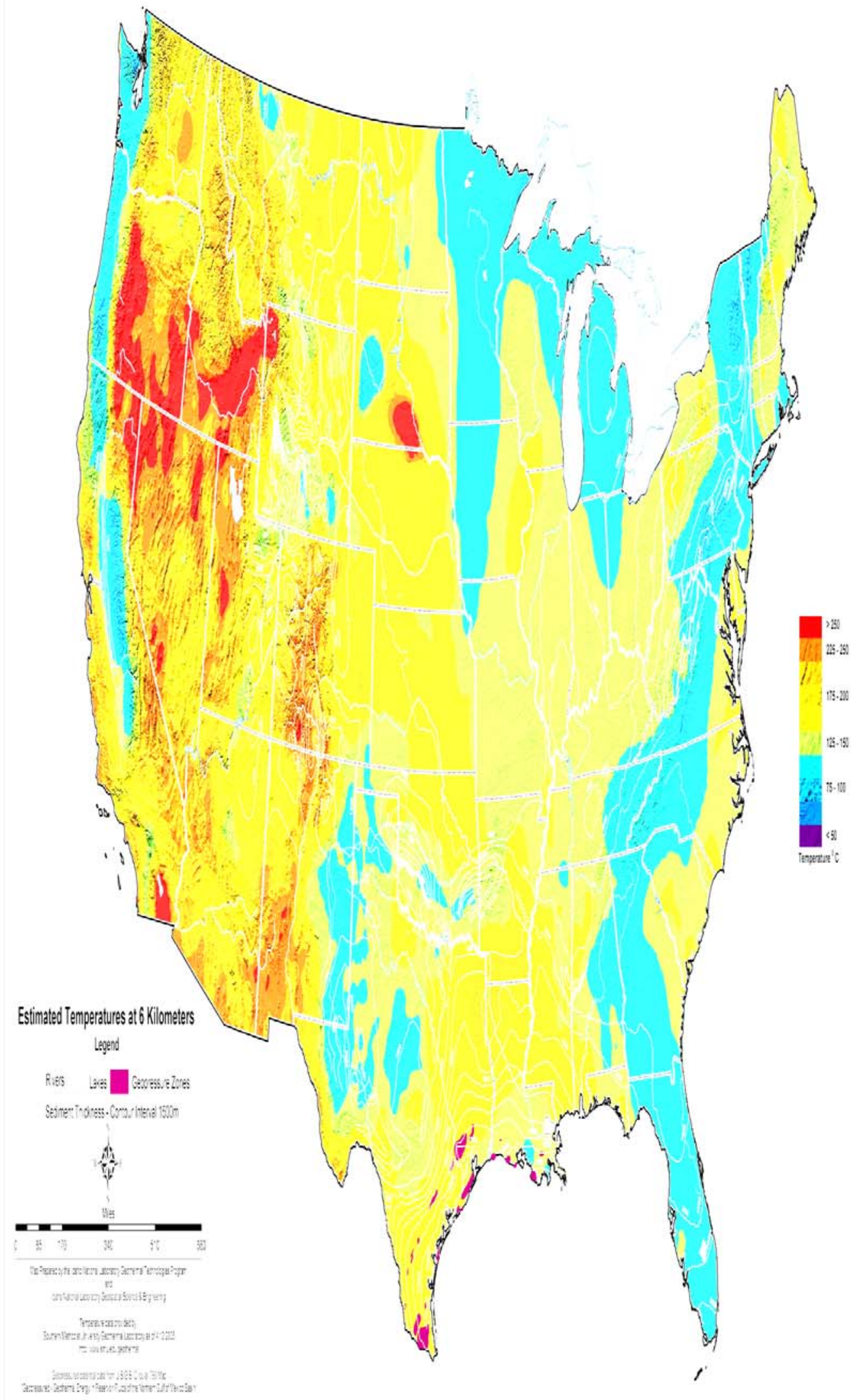

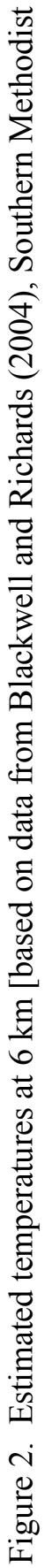


Based on the information from these maps and temperature data, this study was limited to areas in the Western, Mid-continent, and Southern United States. These areas have the greatest potential for early success with EGS technology. Alaska and Hawaii were not included in this drilling study. And because several geothermal operators with proprietary concerns limited the availability of geothermal drilling data in many of these areas, we chose to concentrate on the vast drilling dataset from the oil and gas industry.

We have also incorporated, however, some specific geothermal drilling data from studies by Lovekin and Mansure. Table 1 summarizes depth and cost data representative of geothermal wells completed between 1997 and 2000 in Central America and the Azores (Lovekin et al. 2004). To escalate these prices to account for inflation, the costs of all wells have been escalated to equivalent U.S. dollars as of 1 July 2003, using the Producer Price Index. Figure 3 is a curve fit to the data in Table 1.

Table 1. Drilling costs from 1997 to 2000 for Central America and the Azores.

\begin{tabular}{|c|c|c|c|c|c|c|}
\hline Depth Interval (ft) & $\begin{array}{l}\text { Number } \\
\text { of Wells }\end{array}$ & $\begin{array}{c}\text { Total } \\
\text { Footage }\end{array}$ & $\begin{array}{l}\text { Total Cost } \\
(\$ K)\end{array}$ & $\begin{array}{l}\text { Average Depth } \\
\text { (ft) }\end{array}$ & $\begin{array}{c}\text { Average } \\
\text { Cost/Well }(\$ K)\end{array}$ & $\begin{array}{c}\text { Median } \\
\text { Cost/Well (\$K) }\end{array}$ \\
\hline $0-1,249$ & 1 & 679 & 280 & 679 & 280 & 280 \\
\hline $1,250-2,499$ & 8 & 15,692 & 10,415 & 1,961 & 1,302 & 1,258 \\
\hline $2,500-3,749$ & 0 & 0 & 0 & 0 & 0 & 0 \\
\hline $3,750-4,999$ & 5 & 21,535 & 10,857 & 4,307 & 2,171 & 2,148 \\
\hline $5,000-7,499$ & 24 & 139,757 & 65,081 & 5,823 & 2,712 & 2,482 \\
\hline 7,500-9,999 & 20 & 167,065 & 68,834 & 8,353 & 3,442 & 3,453 \\
\hline $10,000-12,499$ & 3 & 32,968 & 11,495 & 10,989 & 3,832 & 3,913 \\
\hline $12,500-14,999$ & 0 & 0 & 0 & 0 & 0 & 0 \\
\hline $15,000-17,499$ & 0 & 0 & 0 & 0 & 0 & 0 \\
\hline $17,500-19,999$ & 0 & 0 & 0 & 0 & 0 & 0 \\
\hline $20,000+$ & 0 & 0 & 0 & 0 & 0 & 0 \\
\hline Total & 61 & 377,696 & 166,962 & 6,192 & 2,737 & 2,577 \\
\hline
\end{tabular}

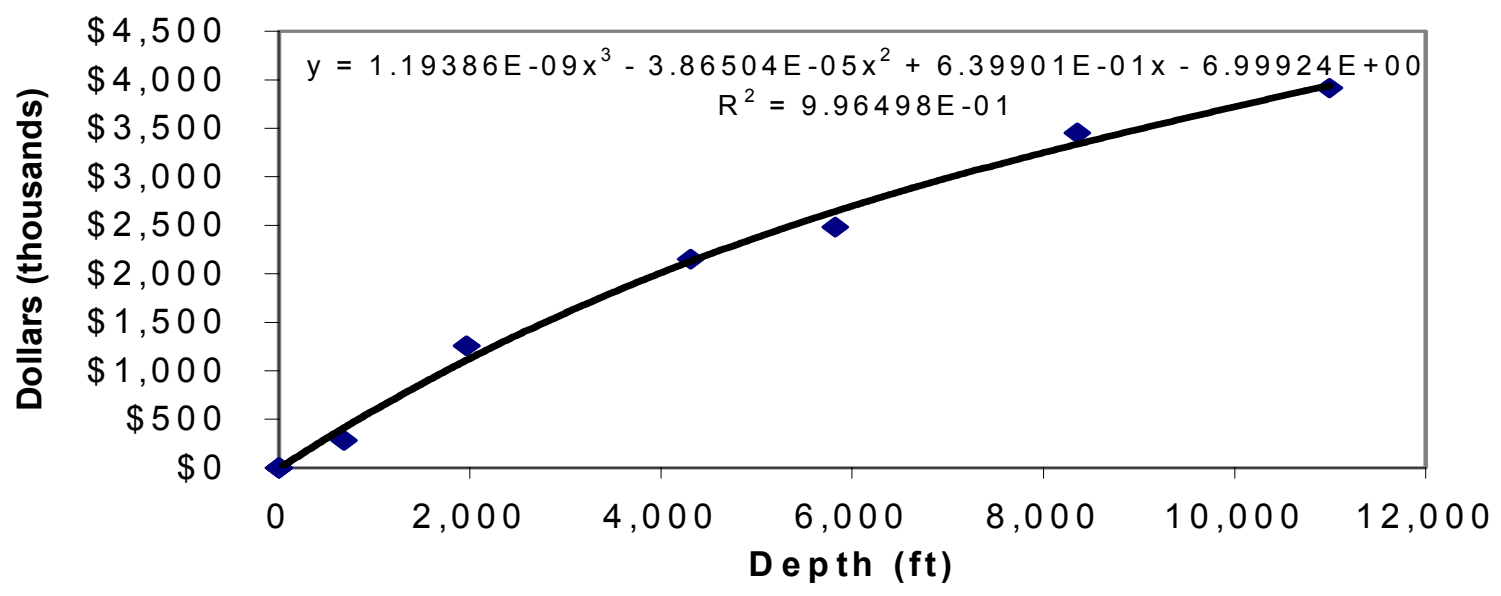

Figure 3. Average depth versus median cost from Table 1 for geothermal wells in Central America and the Azores from 1997-2000 (from Table 1 data). 
Other data available from Sandia National Laboratory (Mansure et al. 2005) show geothermal drilling costs from the 1970s and activity from the mid 1980s through mid 1990s and inflated those cost to 2000 . Table 2 presents the 1970 geothermal drilling costs. Table 3 presents the most recent mid 80 s to mid 90s Sandia drilling data. Both sets of data combined represent less than 100 wells drilled.

Table 2. Geothermal drilling costs from the 1970s.(in year 2000 dollars)

\begin{tabular}{|c|c|c|c|c|c|c|}
\hline Depth Interval (ft) & $\begin{array}{l}\text { Number } \\
\text { of Wells }\end{array}$ & $\begin{array}{c}\text { Total } \\
\text { Footage }\end{array}$ & $\begin{array}{c}\text { Total Cost } \\
(\$ \mathrm{~K})\end{array}$ & $\begin{array}{l}\text { Average } \\
\text { Depth (ft) }\end{array}$ & $\begin{array}{c}\text { Average } \\
\text { Cost/Well }(\$ K)\end{array}$ & $\begin{array}{c}\text { Median } \\
\text { Cost/Well (\$K) }\end{array}$ \\
\hline $0-1,249$ & 0 & 0 & 0 & 0 & 0 & 0 \\
\hline $1,250-2,499$ & 4 & 7,460 & 1,908 & 1,865 & 477 & 369 \\
\hline $2,500-3,749$ & 6 & 18,086 & 7.615 & 3,014 & 1,269 & 1,254 \\
\hline $3,750-4,999$ & 9 & 42,732 & 10,677 & 4,748 & 1,186 & 792 \\
\hline $5,000-7,499$ & 25 & 151,033 & 48,985 & 6,041 & 1,959 & 1,800 \\
\hline 7,500-9,999 & 11 & 94,996 & 27,385 & 8,636 & 2,490 & 2,415 \\
\hline $10,000-12,499$ & 4 & 40,994 & 15,676 & 10,249 & 3,669 & 3,538 \\
\hline $12,500-14,999$ & 0 & 0 & 0 & 0 & 0 & 0 \\
\hline $15,000-17,499$ & 0 & 0 & 0 & 0 & 0 & 0 \\
\hline $17,500-19,999$ & 0 & 0 & 0 & 0 & 0 & 0 \\
\hline $20,000+$ & 0 & 0 & 0 & 0 & 0 & 0 \\
\hline Total & 59 & 355,301 & 111,246 & 6,022 & 1,886 & 1,792 \\
\hline
\end{tabular}

Table 3. Geothermal drilling costs from the mid 1980s through mid 1990. (in year 2000 dollars)

\begin{tabular}{|c|c|c|c|c|c|c|}
\hline Depth Interval (ft) & $\begin{array}{l}\text { Number } \\
\text { of Wells }\end{array}$ & $\begin{array}{c}\text { Total } \\
\text { Footage }\end{array}$ & $\begin{array}{l}\text { Total Cost } \\
(\$ \mathrm{~K})\end{array}$ & $\begin{array}{l}\text { Average } \\
\text { Depth (ft) }\end{array}$ & $\begin{array}{c}\text { Average } \\
\text { Cost/Well (\$K) }\end{array}$ & $\begin{array}{c}\text { Median } \\
\text { Cost/Well }(\$ K)\end{array}$ \\
\hline $0-1,249$ & 0 & 0 & 0 & 0 & 0 & 0 \\
\hline $1,250-2,499$ & 0 & 0 & 0 & 0 & 0 & 0 \\
\hline $2,500-3,749$ & 0 & 0 & 0 & 0 & 0 & 0 \\
\hline $3,750-4,999$ & 0 & 0 & 0 & 0 & 0 & 0 \\
\hline $5,000-7,499$ & 3 & 19,863 & 4,014 & 6,621 & 1,338 & 1,472 \\
\hline $7,500-9,999$ & 17 & 150,297 & 33,684 & 8,841 & 1,981 & 1,892 \\
\hline $10,000-12,499$ & 5 & 52,174 & 8,828 & 10,435 & 1,766 & 1,875 \\
\hline $12,500-14,999$ & 0 & 0 & 0 & 0 & 0 & 0 \\
\hline $15,000-17,499$ & 0 & 0 & 0 & 0 & 0 & 0 \\
\hline $17,500-19,999$ & 0 & 0 & 0 & 0 & 0 & 0 \\
\hline $20,000+$ & 0 & 0 & 0 & 0 & 0 & 0 \\
\hline Total & 25 & 222,334 & 46,526 & 8,893 & 1,861 & 1,792 \\
\hline
\end{tabular}

The Oil and Gas drilling data presented in this paper represent more than 150,000 wells drilled in the Western, Midcontinent, and Southern United States. It includes parts of West and Central Texas (Texas Railroad Commmission Districts 2, 3, 4, 8, and 8A) to represent the higher-temperature anomalies in West Texas as well as the geopressured fairway in South Texas. Drilling data from parts of Arkansas and Northern Lousiana were also examined. More importantly, the areas surveyed and the cost data analyzed would be more representative of an EGS project in the future, since a goal of the Geothermal Technology 
Program (GTP) is to increase the number of states with geothermal power by moving to areas not traditionally considered as prospective geothermal areas. The western states surveyed are California, Colorado, Montana, New Mexico, Texas District 8 and 8a, Utah, and Wyoming. Nevada drilling data were not available but drilling costs are assumed to be comparable with Utah's. Other states included in this report are Kansas, Oklahoma, and North Dakota, which allowed the study to increase the samples in the data sets for the median and deeper depths of 10,000 to 20,000 feet for comparison with states most likely to construct an EGS project. The majority of the data reported here are historical oil and gas drilling costs from Oil \& Gas Journal and the most recent 2003 Joint Association Survey on Drilling Costs, issued in March 2005. In addition, Appendix A presents some Authority for Expenditures (AFEs), which provide a more detailed picture of drilling costs for some wells in Texas, Oklahoma, and Montana drilled in the last six months or scheduled for drilling shortly. Because of the proprietary nature of the JAS survey data, we do not provided the detailed tables of data but rather data that has been analyzed and graphed. The data presented in the graphs includes the depth in feet and costs in thousands of dollars.

From the historical data, it is apparent that drilling activity (rig demand) drives drilling costs. The level of activity accounts for a large percentage of drilling cost changes. Hence, costs can be expected to rise as activity levels increase, particularly during short-term, cyclical activity spikes (OGJANN). Figure 4 illustrates the median costs of a 10,000-ft well from 1970 through 2001 and the cyclical pattern of those costs.

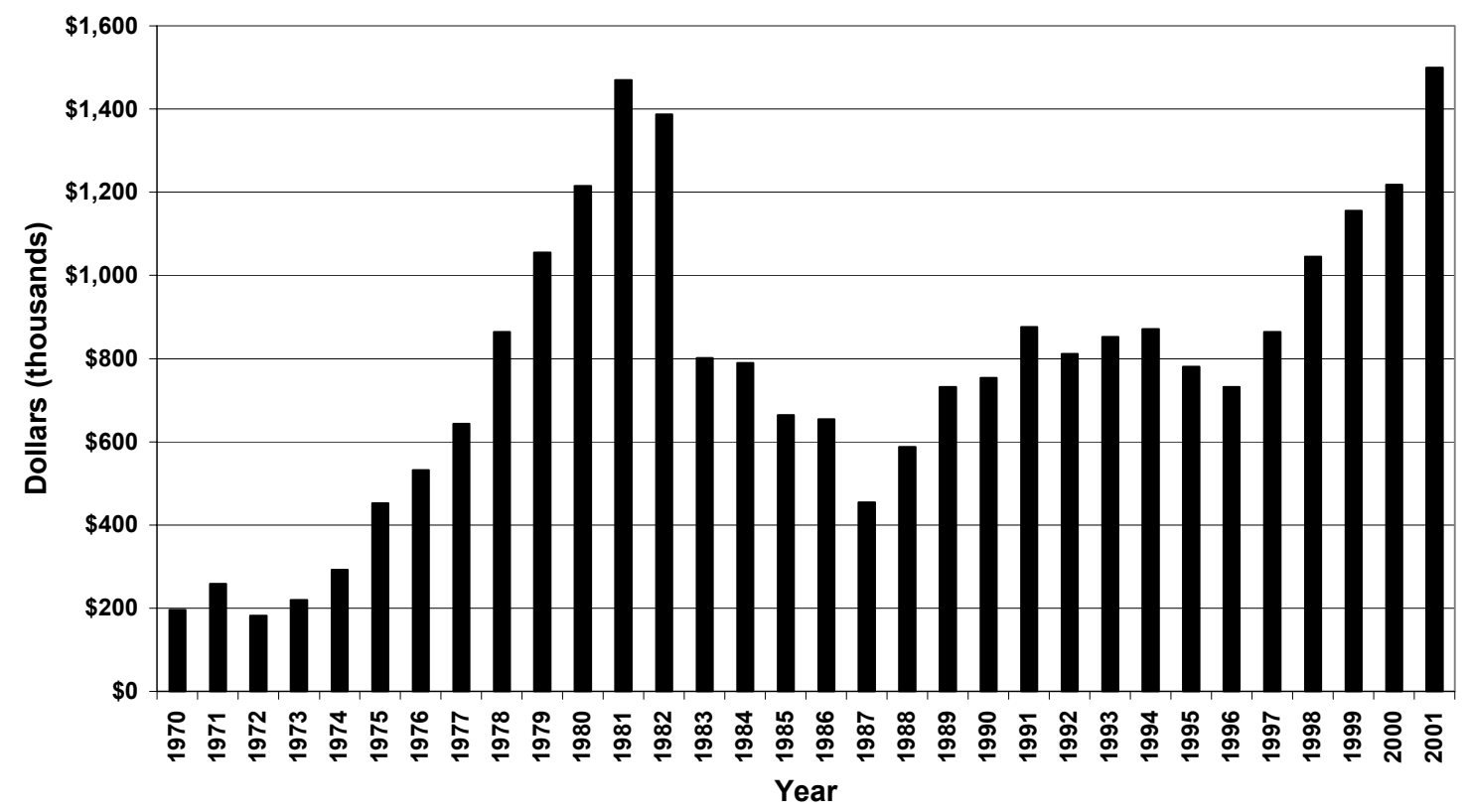

Figure 4. Cyclical example of the cost of drilling a 10,000-ft well. (these costs are not normalized to 2003 dollars)

Increases in oil/gas prices translate directly into higher drilling costs. Rising prices spur drilling of additional marginal wells. These drive up costs because they are more challenging projects. Higher prices also increase drilling costs because energy costs are a major component of total drilling costs, which include such material costs as casing, cement, and transportation to deliver materials to the drilling site.

U.S. onshore rig counts have been declining since 1981. Declining rig population creates a tighter rig market. Until day rates increase sufficiently to justify investment in construction, the market will continue to become tighter. Ultimately, this will lead to higher rates and drilling costs. A tight market is needed 
over a sustained period to achieve day rates that justify new equipment. In a tight market, day rates are likely to increase until they reach levels that trigger new equipment investments.

Advances in drilling technologies have increased (and will continue to increase) efficiencies, resulting in lower overall costs. These gains mean rates will reflect the benefits/costs of advanced technology in most cases. However, new technologies could produce higher day rates for certain rigs, which provide offsetting benefits by requiring fewer drilling days.

The 2003 Joint Association Survey of Drilling costs report the total cost of each well completed by the operator or contractor. This includes tangibles and intangibles. More specifically, the cost elements include labor, materials, supplies, water, fuel, and power. Direct overhead charges are also included for operations, such as site preparation, road building, mobilization, and demobilization and hauling costs. This report does not include wells that involved sidetracking operation. The drilling cost data also includes the cost of horizontal wells. The JAS survey does differentiate from the higher concentration of horizontal wells in Texas, Louisiana, and the Gulf of Mexico. These areas accounted for one fourth of the horizontal wells drilled. The average cost of per foot for a horizontal well was $17 \%$ higher than a well not drilled horizontally. Horizontal drilling averaged \$254/ft verses \$217/ft for a standard hole. 


\section{DISCUSSION}

The objective of drilling is to reach the target depth or pay zone at the lowest cost, highest degree of safety, and minimal degree of damage to formation. To achieve this, two requirements must be satisfied. The first is proper design of the well program, which includes evaluating the formation, coring, and testing. The second is proper choice of a drilling rig, which includes the ability to reach the target depth rapidly and cheaply with the highest degree of safety. The well program is $40 \%$ of the well costs (Chilingarian and Vorabutr 1983). The remainder of the cost is proportional to the time for drilling, which includes rig day rate, rental tools, etc. A distribution of the well program cost follows:

1. Fixed costs, which includes location or site preparation and roads: $8-12 \%$

2. Fixed costs, which includes moving, casing, cementing, service companies, evaluation of formation, coring, etc.: $23-27 \%$

3. Completion, which includes perforating and site cleanup: 4-6\%.

Proper planning of the well is key to optimizing operations and minimizing expenditures. In order to minimize the costs of drilling, it is imperative to gather as much information as possible about the area being drilled. This includes the gathering the costs from surrounding wells. Although gathering specific costs of drilling is beyond the scope of this project, a short summary is included to detail what information should be gathered before a drilling venture is undertaken.

The first step in planning a well is to gather all available data on past wells. It is important to be completely familiar with all sources of information, the availability of the sources, and the information normally associated with the sources.

Consider the geology expected to be encountered to reach the target depth. Knowing the geology will help determine casing depths, such as the depth of fresh water. Competent geology will determine surface casing requirements. Understand the production objective of the well, such as hole size, production casing requirements, and completion requirements. Know the geologic markers, along with the anticipated formation tops, to determine other well planning activities such as logging, formation testing, and cores.

The information to successfully complete the well program can be obtained from an adjacent well or "control wells." Obtain such information as mud logs, electric logs, bit records as well as drilling rig inventory where available to determine the most cost-effective procedures in drilling a well. 


\section{PLOTS}

The plots and curve fits for the different regions and states are presented as average depth verses median cost. The median cost was chosen because the average cost per well was not always a good representation of the central tendency of the depth interval. For example, a few very expensive wells can skew the average toward higher cost and away from the middle range of data. The result would be an average cost higher than the cost of a typical well. The median cost per well is unaffected by very high or low cost. By definition, the median of a set of data is the data point that divides the set in half so that an equal number of the data points are both larger and smaller than the median. Since these well costs were drilled in 2003, results are expressed in 2003 dollars.

The basic idea of curve fitting and statistics is simple: you want to utilize the data you collected to make general conclusions about the larger population from which the drilling cost were derived. That is, analyze this drilling depth and cost data and use the results to infer the cost with depth.

Appendix B presents a series of plots for each region and state studied. Data are presented with curve fits for the total range of depths for each state and then curve fitted in increments from 0 to $8,000 \mathrm{ft}$ average depth and 8,000 to 20,0000 ft average depth. Three sets of curve fits for cost verses depth are presented in the appendix. The curve fits are polynomial, exponential, and power type.

\subsection{Polynomial Curve Fitting}

Polynomial regression fits data to the following equation: $y=A+B x+C x^{2}+D x^{3}+E x^{4} \ldots \ldots$. where $y$ is cost and $x$ is depth. Any number of terms can be included. If you stop at the second (B) term, it is called a first-order polynomial equation, which is identical to the equation for a straight line. If you stop after the third $(\mathrm{C})$ term, it is called a second-order, or quadratic, equation. If you stop after the fourth term, it is called a third-order, or cubic, equation.

Correlation quantifies how consistently the two variables vary together. When the two variables vary together, statisticians say that there is a lot of correlation. The direction and magnitude of correlation is quantified by the correlation coefficient, $\mathrm{R}$. The polynomial curve fits displayed the best correlation for or regression for most of the oil and gas cost data. For specific details see curve fits in appendix B.

\subsection{Exponential Curve Fitting}

The exponential growth curve fit is also used to fit the cost versus depth data. The exponential growth fits data to the equation $y=A e^{B x}$. It is difficult to fit data to this equation with nonlinear regression because a tiny change in the initial values will drastically alter the sum of squares.

\subsection{Power Series Curve Fitting}

The power series curve fit defined by the equation $y=A x^{B}$ is very versatile and has many uses. Fitting data to a power series is difficult for the same reason as exponential growth. The initial values of $\mathrm{A}$ and $\mathrm{B}$ are important, because small changes in those values can make a huge change in $y$ or well cost. 


\section{CONCLUSIONS}

A review of drilling costs with depth has been generated for regions and states of potential EGS sites. Publicly available geothermal drilling cost data are very limited. Geothermal drilling cost information for depths greater than 10,000 feet is so limited as to make it statistically unreliable for cost estimating purposes. Since EGS development might occur at depths greater than 10,000 feet, references to oil and gas drilling costs should be considered when determining an EGS project cost and the economics of power production from these depths and reservoir types. 


\section{REFERENCES}

2003 Joint Association Survey on Drilling Costs, 2005, American Petroleum Institute.

Chilingarian G., and R. Vorabutr 1983, Drilling and Drilling Fluids, Appendix G, New York, Amsterdam: Elsevier, p.765-778.

Blackwell D., and M. C. Richards 2004, "The 2004 Geothermal Map of North America, Explanation of Resources and Applications," Geothermal Resource Council Transactions, Vol. 28, pp. 317-320.

Lovekin J., C. W. Klein, and S. K. Sanyal 2004, New Geothermal Site Identification and Qualification, California Energy Commission, P500-04-051, p. 29.

Mansure A., S. J. Bauer, B. J. Livesay, 2005, “Geothermal Well Cost Analyses 2005," Geothermal Resource Council Transactions, Vol. 29, in press.

Moore P. L., Drilling Practices Manual, Tulsa, Oklahoma: PennWell Books, 1974, pp. 3-72.

Oil and Gas Journal Annual, Haver Analytics, April 19, 2004, http://www.Haver.com. 


\section{Appendix A}

\section{Authority for Expenditures}




\section{Appendix A}

\section{Drilling Authority for Expenditure: Examples}

In order to put the 2003 Joint Association Survey on Drilling Costs information in perspective, we compare it to some current drilling cost information. This appendix presents eight Authority for Expenditures (AFEs) prepared by a drilling engineer for wells that have been or will be drilled in 2005. Because of the proprietary nature of these cost data, some of the descriptive information (i.e., lease/well name, operator, location, etc.) has been removed, but none of the information used to calculate the cost has been changed or removed.

The AFEs include both oil and gas wells, a directionally drilled well, and a multilateral completion. The wells are in Texas, Oklahoma, and Montana and range in depth from 900 to 13,200 feet (274 to 4,023 meters). Data in the AFEs include cost for items such as surveying, rig mobilization, drilling day work, bits, logging, casing, perforating, etc. Each AFE has three pages: a cover sheet, a drilling well cost estimate, and a completion cost estimate. 


\section{Location: Hill Co., MT; Well Type: Gas; Total Depth: 900 ft ( 274 m)}

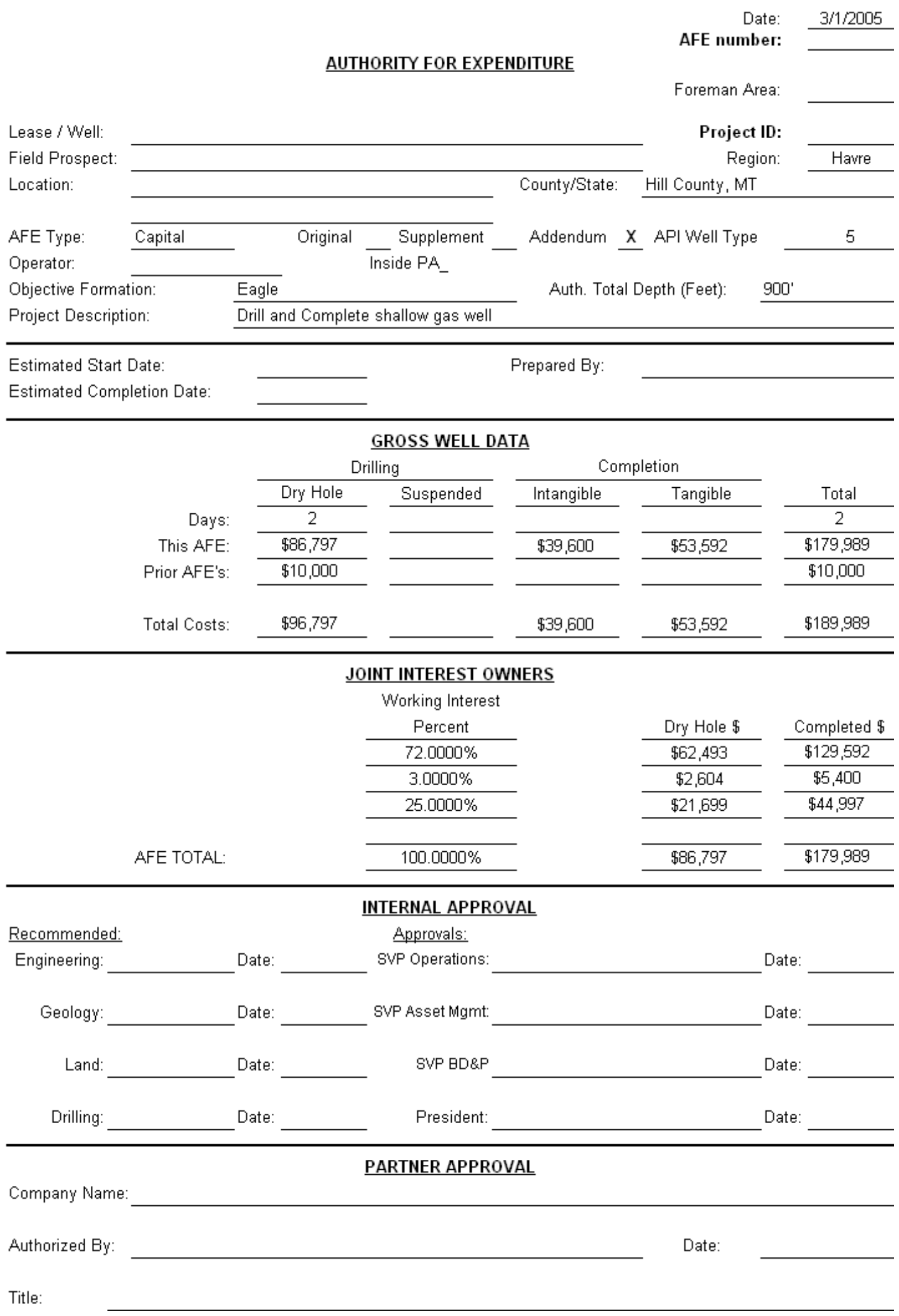


DRILLING WELL COST ESTIMATE

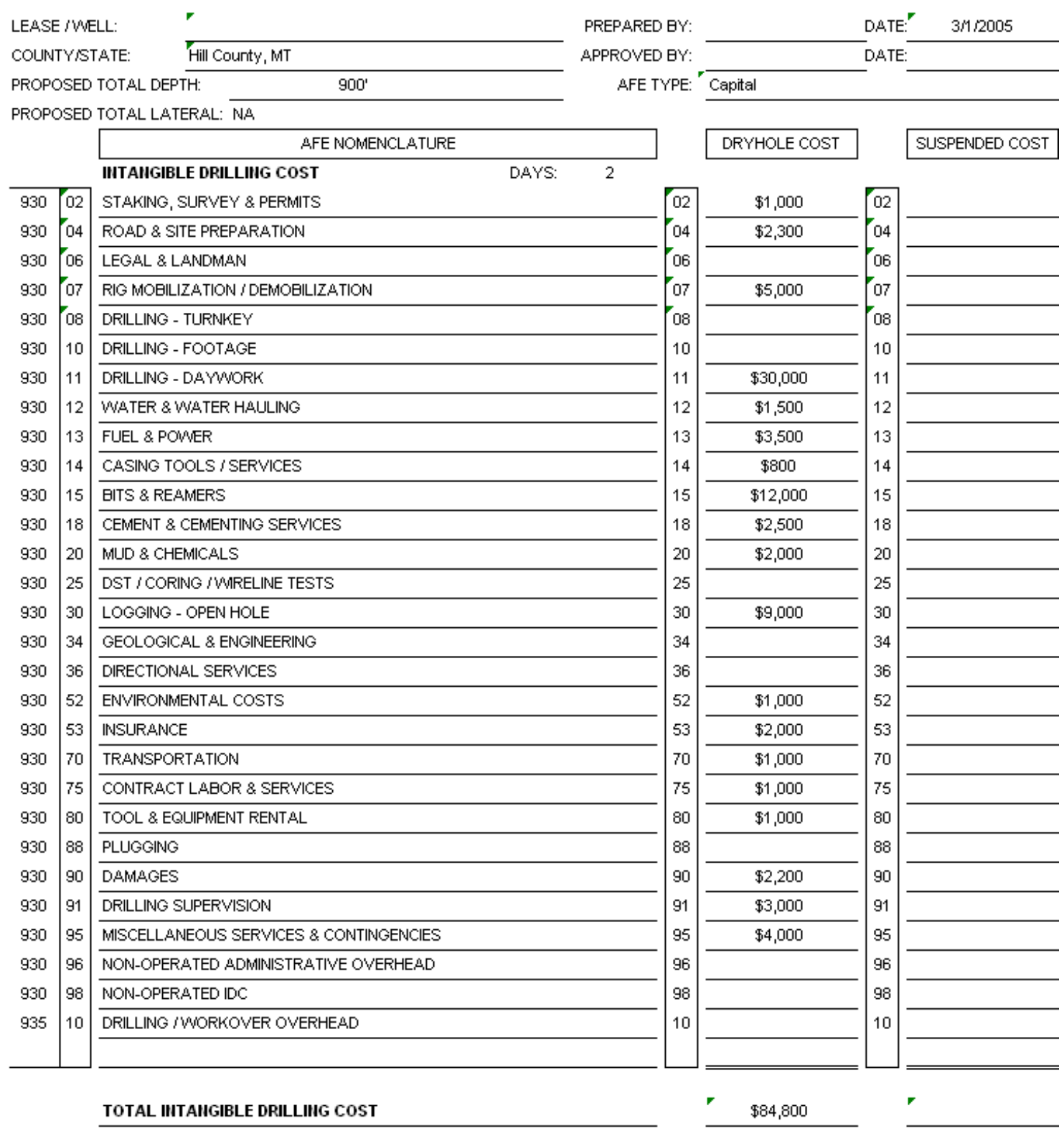

\section{TAIIGIBLE DRILLIIIG COST}

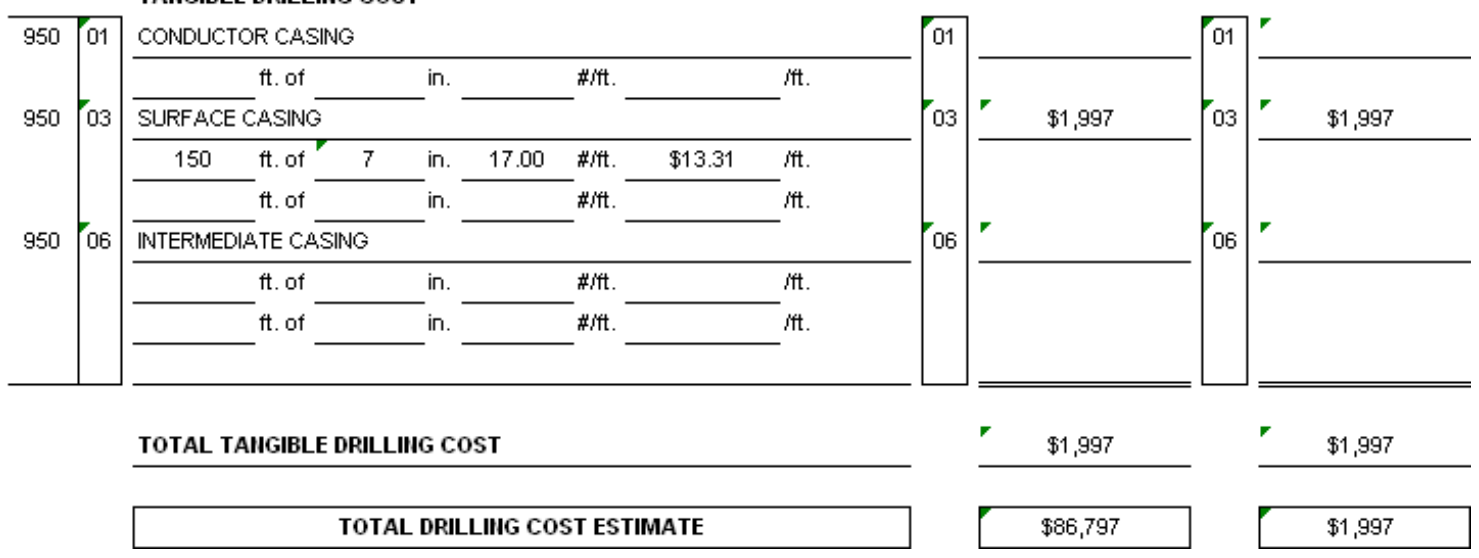


COMPLETION COST ESTIMATE

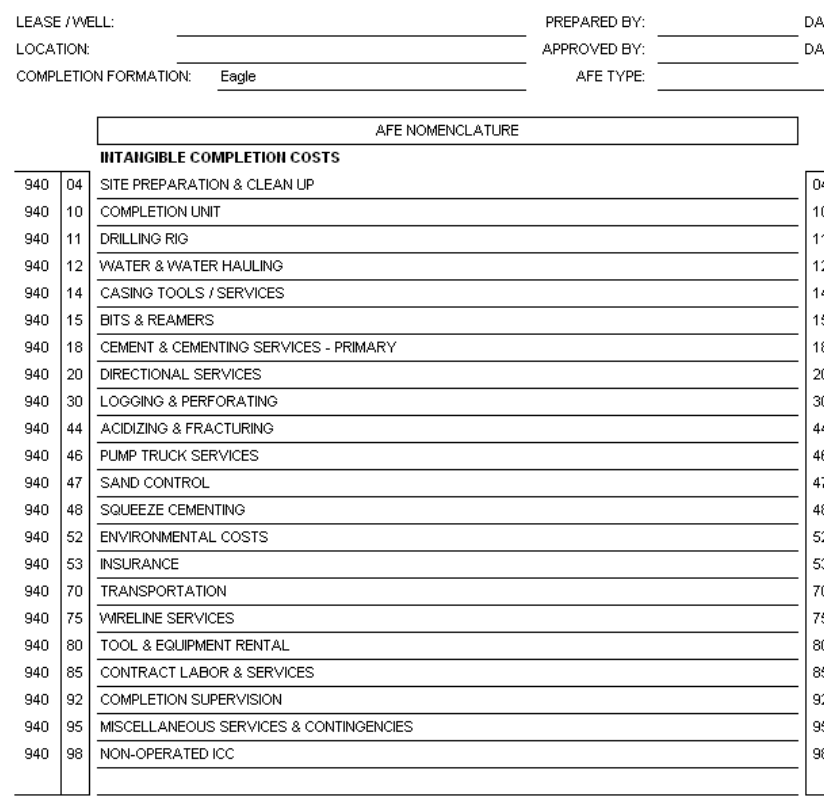

DATE: 3/12005 DATE

ESTIMATED COST

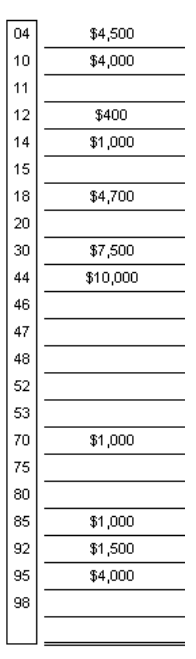

TOTAL IIITAIGIBLE COMPLETION COST

$\$ 39,600$

TAIGGBLE COMPLETIOI $\cos$

$955|02|$ CASING HEAD

95504 DirT \& DOZ

95505 PRODUCTION CASING

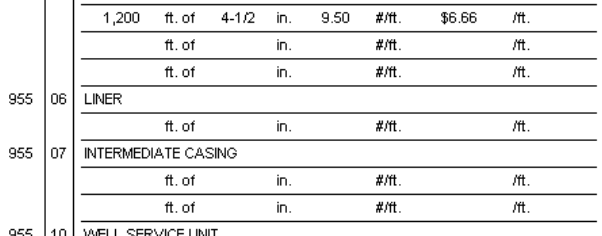

95512 TUEING HEAD

95514 TUBING

95516

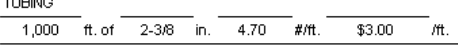

RODS $\begin{array}{lllllll} & \text { it. of } 2-3 / 8 & \text { in. } & 4.70 & \text { \#/ft. } & \$ 3.00 & \text { ift. } \\ \text { ft. of } & & \text { in. } & & \text { \#/ft. } & & \text { /ft. }\end{array}$

tt. of

of

ft. of

MELLHEAD EQUIPMENT

$1 8 \longdiv { \text { SUISURFACE EQUIPMENT } } -$

95520 PUMPING UNNT

22 ENGINE

MOTOR

PUMPS

ELECTRICAL EQUIPMENT

STORAGE TANKS

TREATING EQUIPMENT

DEHYDRATION EQUIPMENT

SEPARATION EQUIPMENT

COMPRESSION

FITTINGS, CONNECTIONS \& VALVES

LINE PIPE

GAS MEASUREMENT EQUIPMENT

GAS INJECTION EQUIPMENT

70 TRUCKING

ROUSTABOUT \& GENER,AL LABOR

MISCELLANEOUS

PROPERTY ACQUISITION

NON-OPERATED EQUIPMENT COSTS

$\longrightarrow$

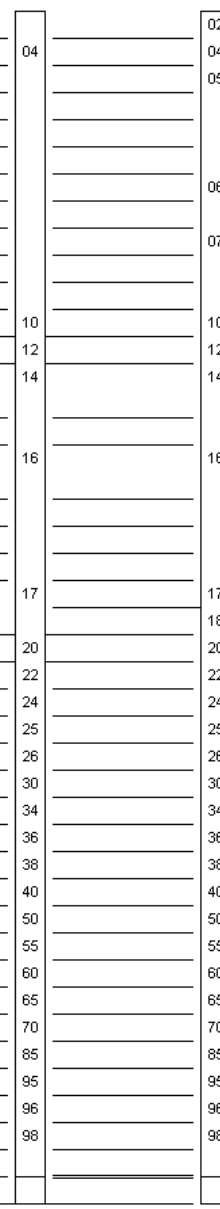

TOTAL TAIGGBLE COMPLETIOI COST

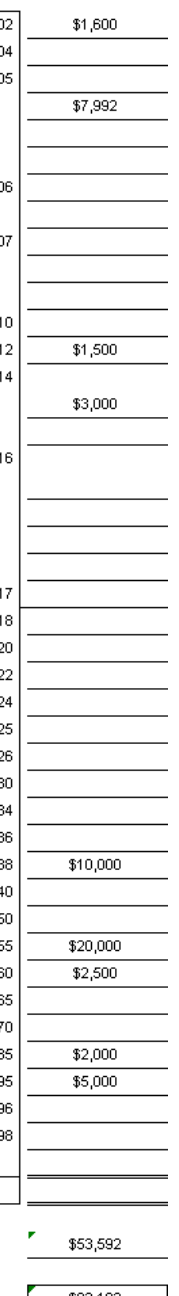

TOTAL COMPLETIOII COST ESTIMATE

$\$ 93,192$ 
Location: Crane Co., TX (Dist 8); Well Type: Gas; Total Depth: 3,400 ft (1,036 m)

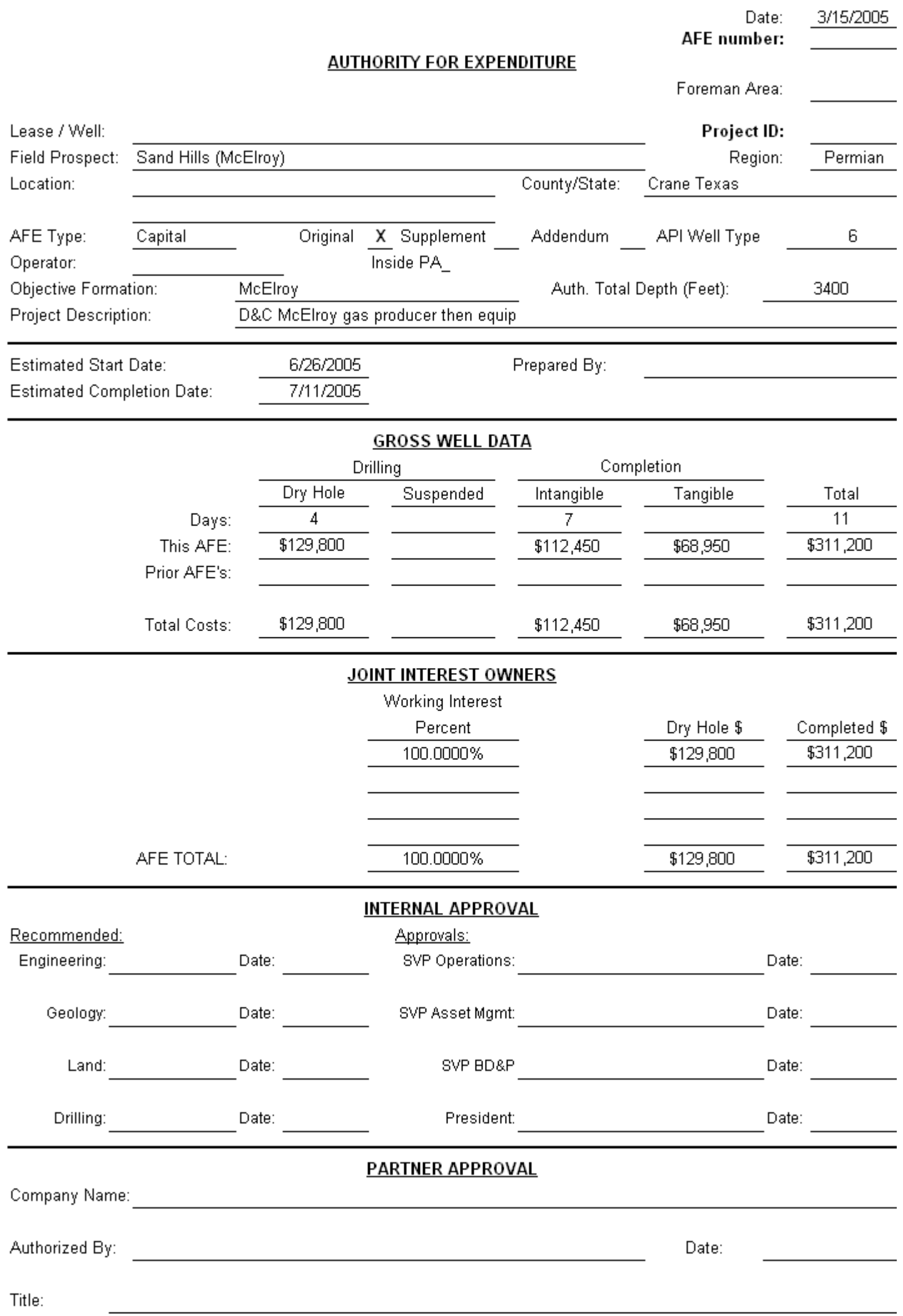


DRILLING WELL COST ESTIMATE

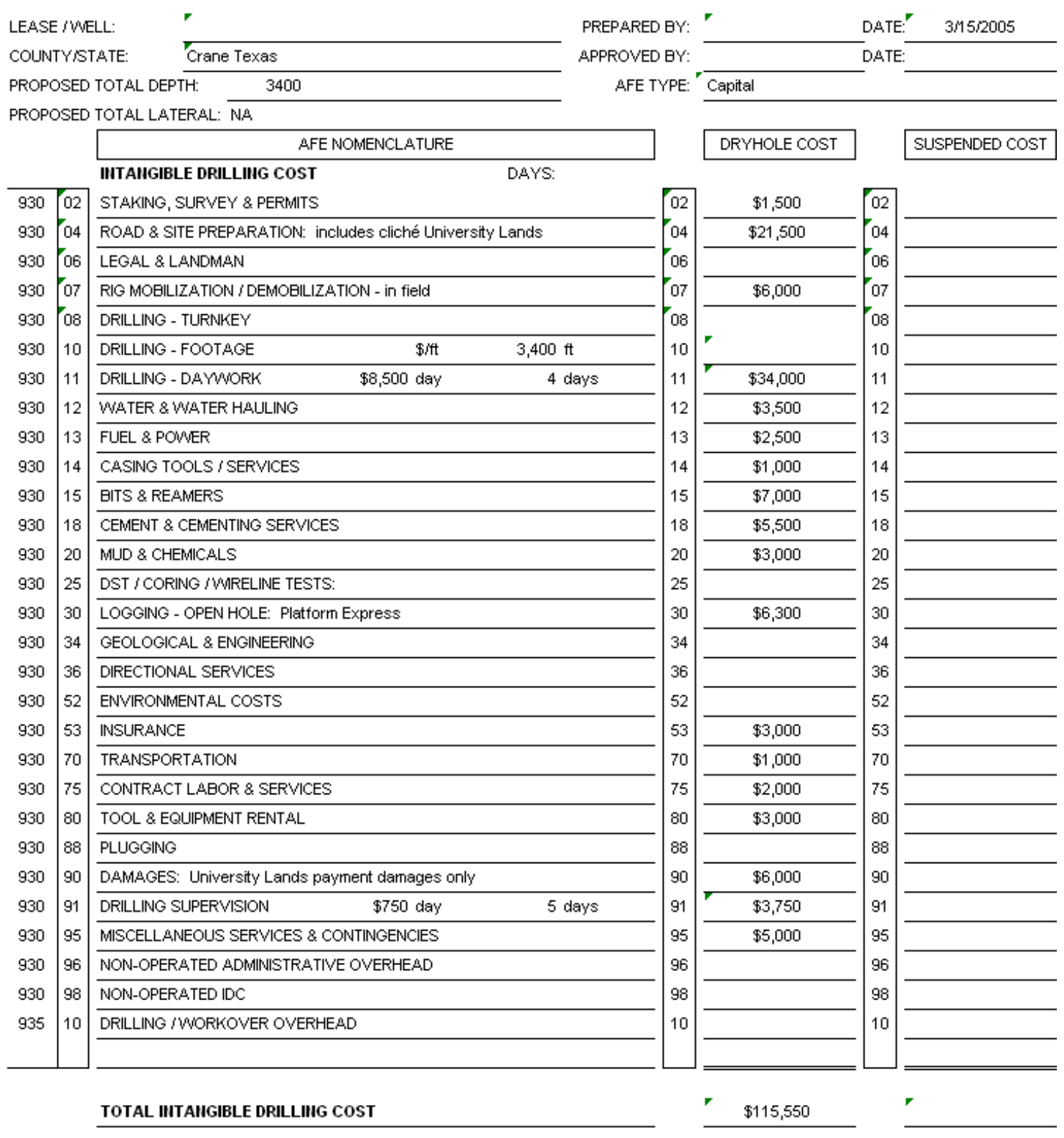

\section{TAIIGIBLE DRILLIIIG COST}

\begin{tabular}{|c|c|c|c|c|c|c|c|c|c|c|c|c|}
\hline 950 & 01 & CONDUCTC & DR CAS & & & & & & 01 & $\$ 4,500$ & 01 & 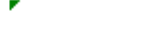 \\
\hline & & 40 & ft. of & 14 & іп. & \#/ft. & & ift. & & & & \\
\hline 950 & 03 & SURFACE & CASING & & & & & & 03 & $\$ 9,750$ & 03 & $\$ 9,750$ \\
\hline & & 650 & ft. of & 7.000 & 20.00 & \#/ft. & $\$ 15.00$ & ift. & & & & \\
\hline & & & ft. of & & in. & \#/ft. & & ift. & & & & \\
\hline 950 & 06 & INTERMEDI & ATE CA & INNG & & & & & 06 & 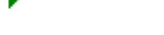 & 06 & 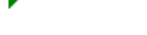 \\
\hline & & & ft. of & & in. & \#/ft. & & ift. & & & & \\
\hline & & TOTAL TA & IIIGIBLI & DRILL & G $\cos T$ & & & & & $\$ 14,250$ & & $\$ 9,750$ \\
\hline & & & & TOTA & DRILLIIIG Ce & T EST & ATE & & & $\$ 129,800$ & & $\$ 9,750$ \\
\hline
\end{tabular}


COMPLETION COST ESTIMATE

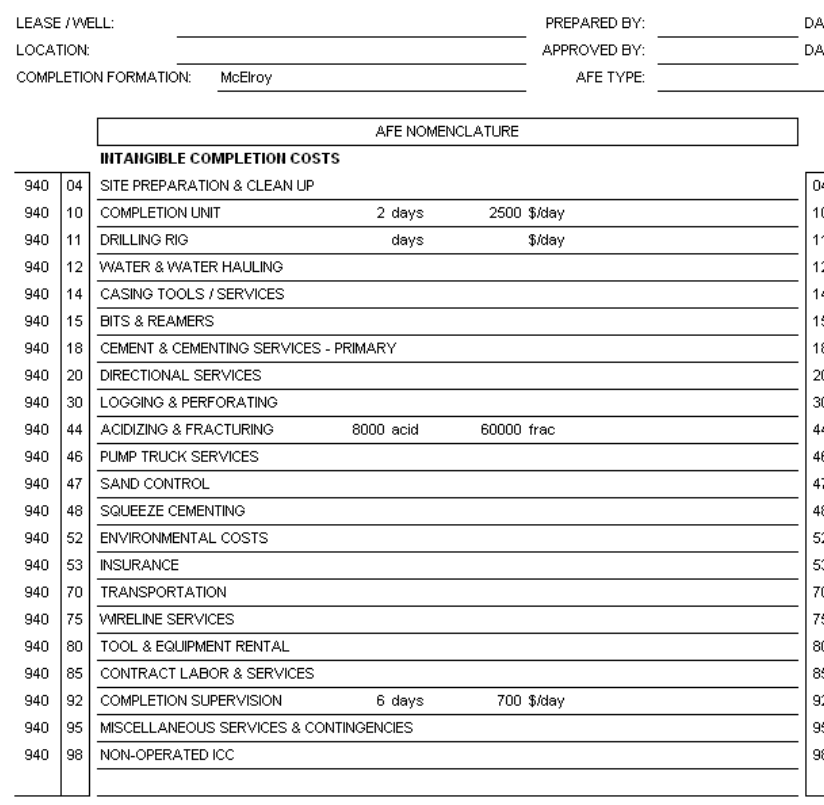

DATE: $\quad 3 / 15 / 2005$

ESTIMATED COST

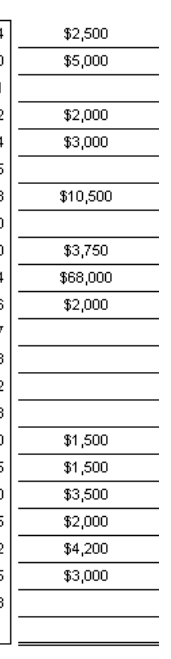

TOTAL IIITAIGIBLE COMPLETION COST

$\$ 112,450$

TAIGGBLE COMPLETION $\operatorname{Cos}$

$955|02|$ CASING HEAD

95505 PRODUCTION CASING

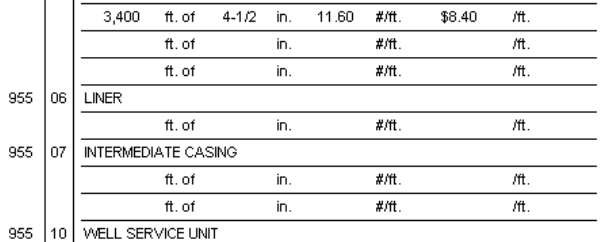

95512 TUEING HEAD

95514 TUEING

955

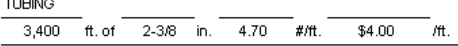

RODS $\begin{array}{lllllll}\text { ft. of } & 2-3 / 8 & \text { in. } & 4.70 & \text { \#/ft. } & \$ 4.00 & \text { ift. } \\ \text { ft. of } & & \text { in. } & & \text { \#/fit. } & & \text { ift. }\end{array}$ $\begin{array}{ccc}\text { ft. of }_{\text {ft. of }} & \text { in. } & \text { in. }\end{array}$

$$
\begin{array}{r}
\text { ft. of } \\
\hline \text { tt. of }
\end{array}
$$

95517 MELLHEAD EQUIPMENT

$9 5 5 1 8 \longdiv { \text { SUBSURFACE EQUIPMENT } } -$

95520 PUMPING UNNIT

95522 ENGINE

95524 MOTOR

95525 PUMPS

95526 ELECTRICAL EQUIPMENT

95530 STORAGE TANKS

955 TREATING EQUIPMENT

95536 DEHYDRATION EQUIPMENT

95538 SEPARATION EQUIPMENT

95540 COMPRESSION

95550 FITTINGS, CONNECTIONS \& VALVES

95555 LINE PIPE

95560 GAS MEASUREMENT EQUIPMENT

95565 GAS INJECTION EQUIPMENT

955 70 TRUCKING

95585 ROUSTABOUT \& GENERAL LABOR

95595 MISCELLANEOUS

95596 PROPERTY ACQUISITION

95598 NON-OPERATED EQUIPMENT COSTS

-

TOTAL TAIGGBLE COMPLETIOI $\cos$
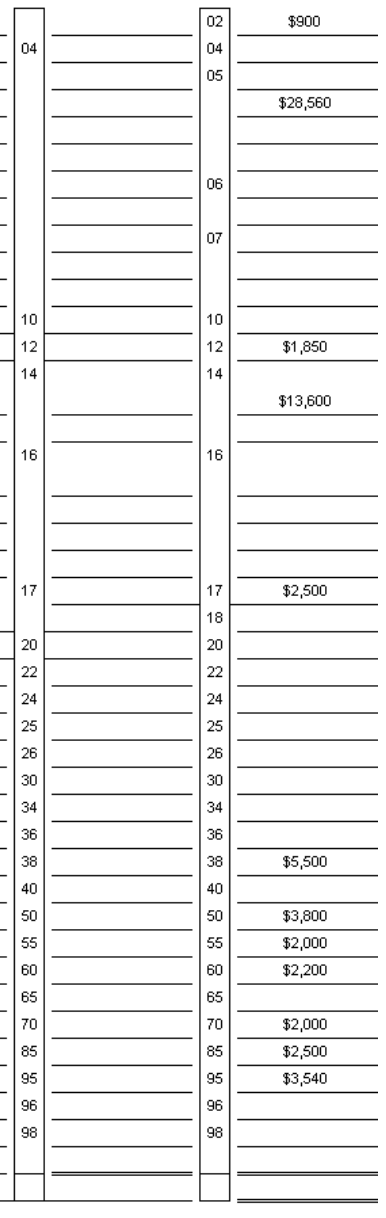
Location: Andrews Co., TX (Dist. 8); Well Type: Oil; Total Depth: 4,750 ft (1,448 m)

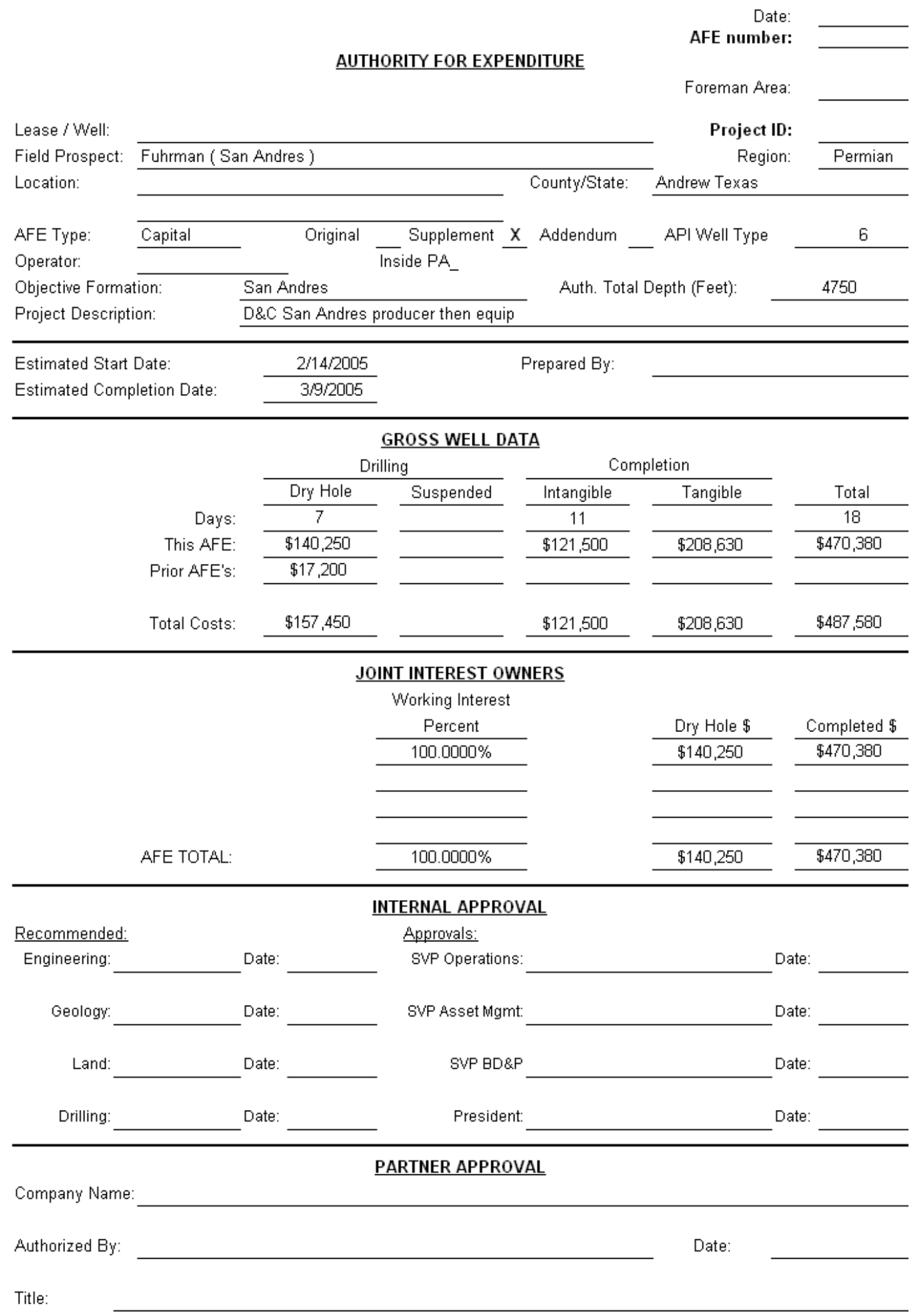


DRILLING WELL COST ESTIMATE

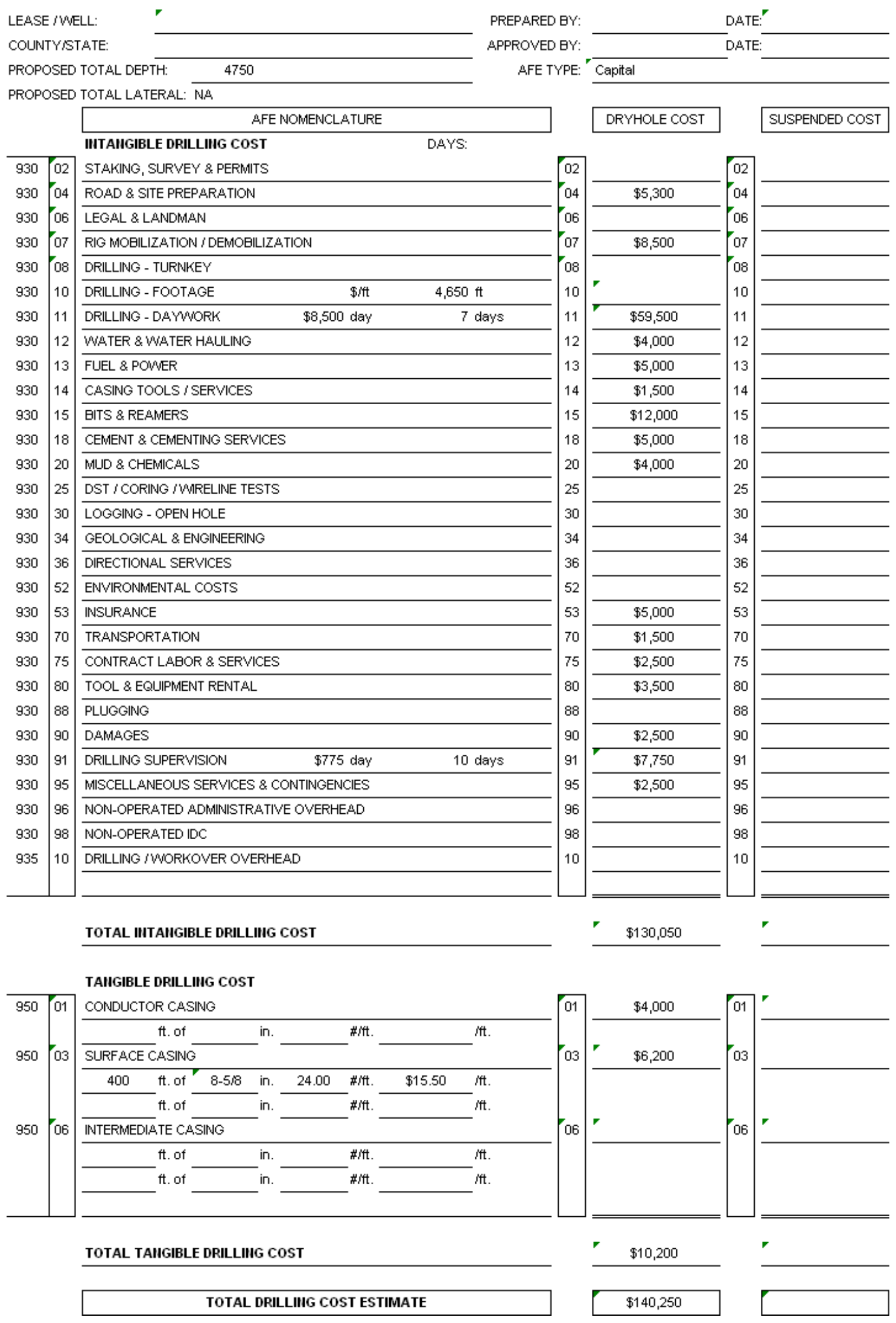


COMPLETION COST ESTIMATE

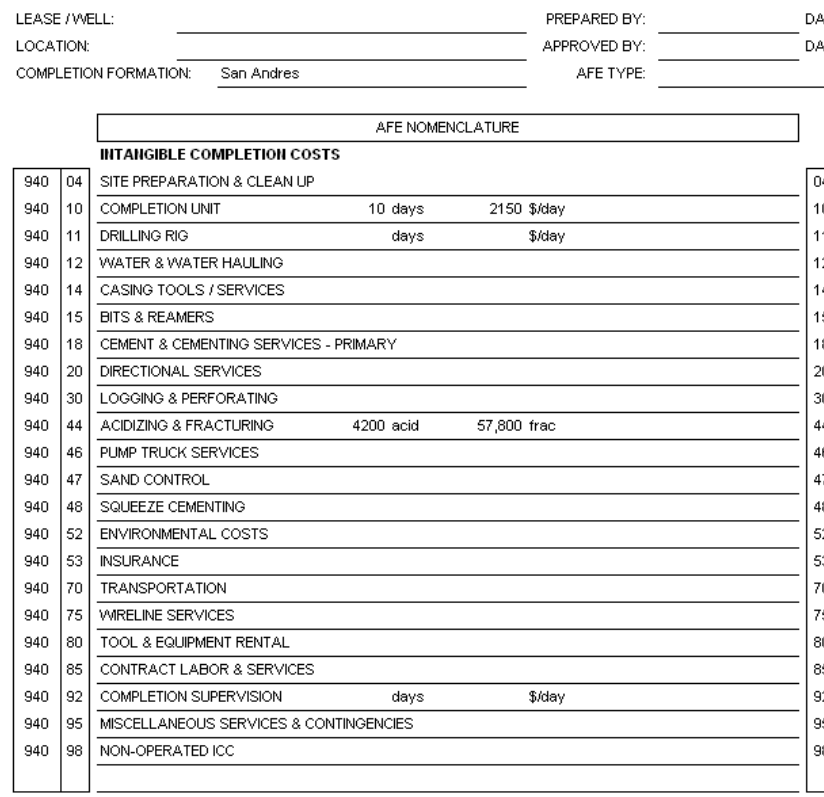

DATE

ESTIMATED COST

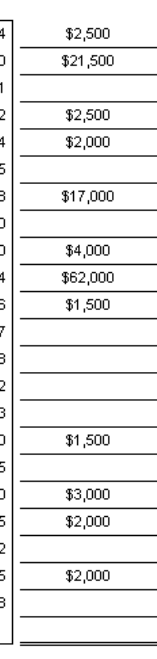

TOTAL MITAIIGIBLE COMPLETIOI COST

$\$ 121,500$

\section{TAIGGBLE COMPLETIOII COST}

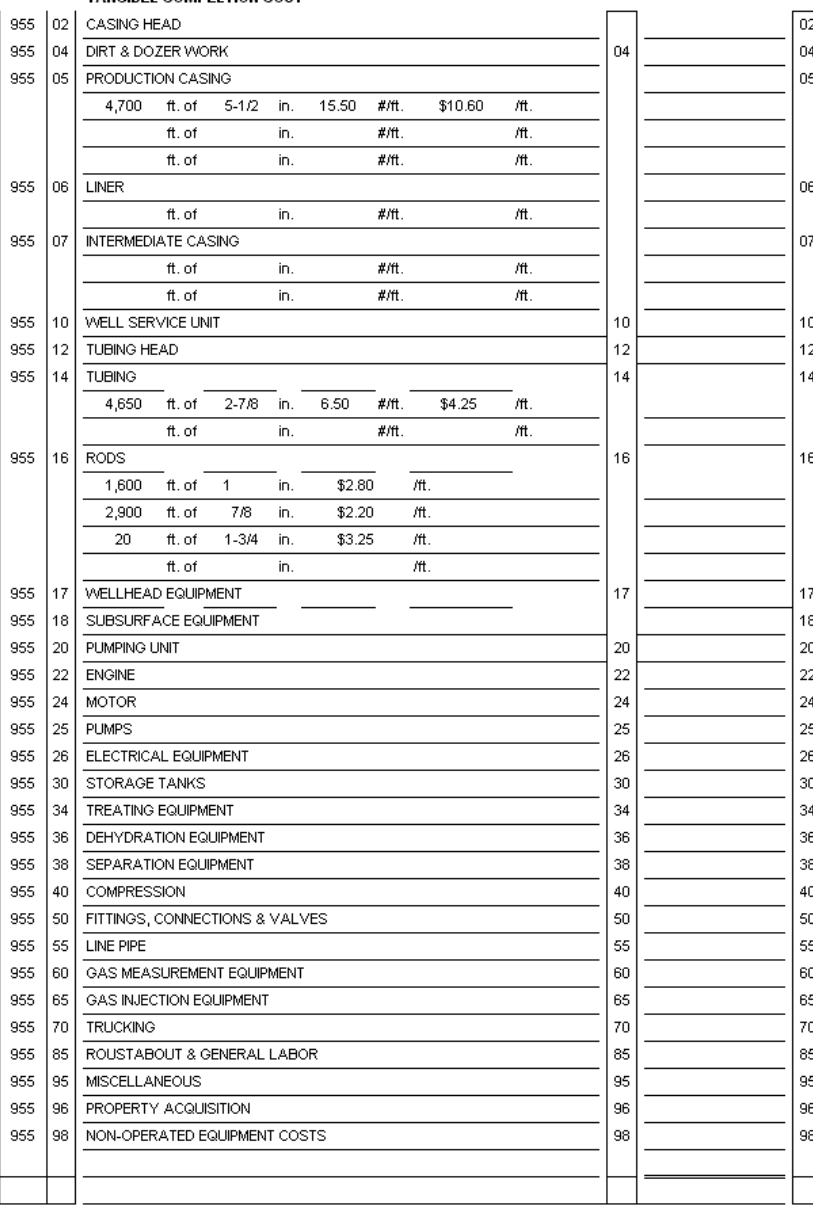

TOTAL TAIGGBLE COMPLETIOI COST

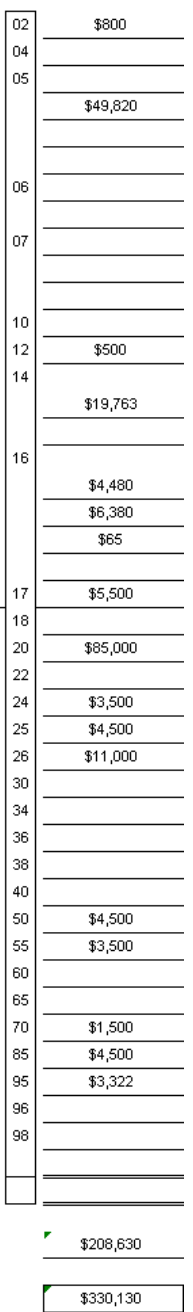

TOTAL COMPLETIOI COST ESTIMATE 


\section{Location: McClain Co., OK; Well Type: Oil \& Gas; Total Depth: 8,850 ft (2,697 m)}

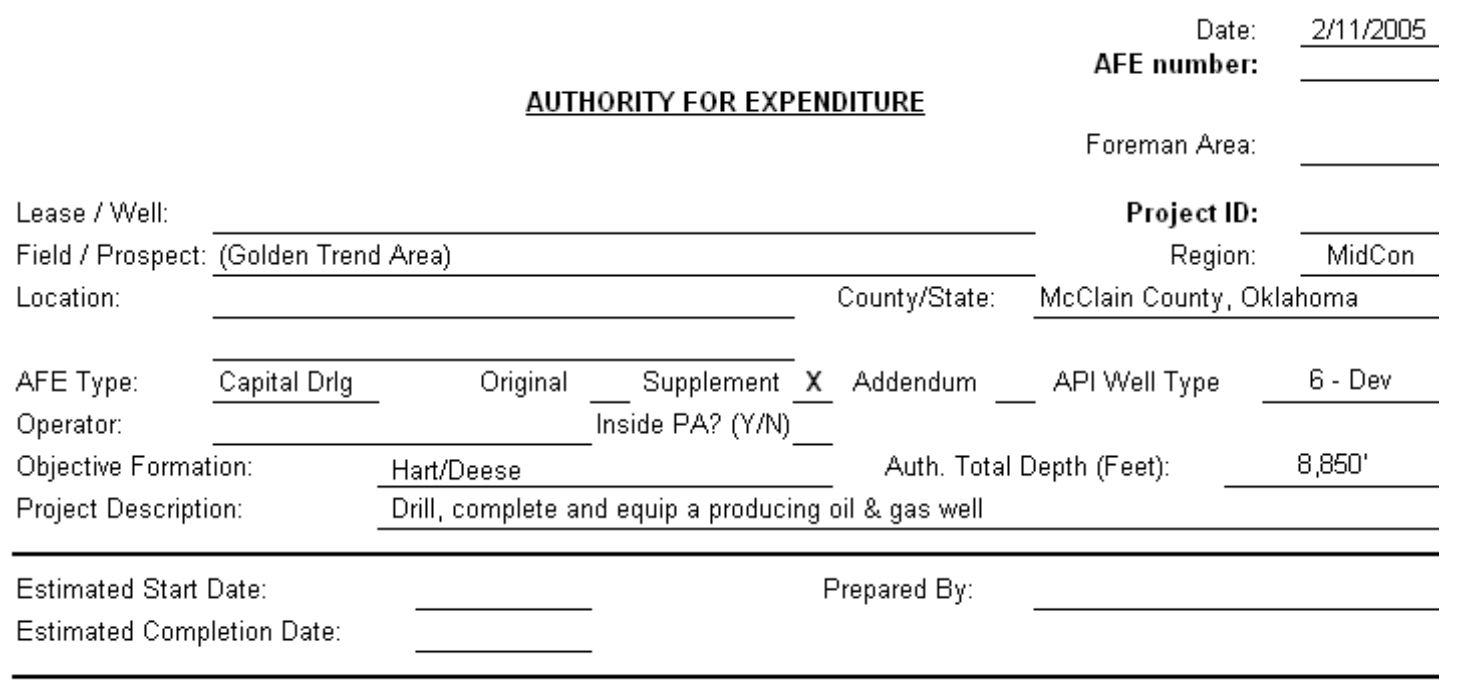

GROSS WELL DATA

\begin{tabular}{|c|c|c|c|c|c|}
\hline & \multicolumn{2}{|c|}{ Drilling } & \multicolumn{2}{|c|}{ Completion } & \multirow[b]{2}{*}{ Total } \\
\hline & Dry Hole & Suspended & Intangible & Tangible & \\
\hline Days: & 0 & & & & 0 \\
\hline This AFE: & $\$ 695,000$ & & $\$ 437,200$ & $\$ 319,800$ & $\$ 1,452,000$ \\
\hline Prior AFE's: & $\$ 48,000$ & & $\$ 0$ & $\$ 0$ & $\$ 48,000$ \\
\hline Total Costs: & $\$ 743,000$ & & $\$ 437,200$ & $\$ 319,800$ & $\$ 1,500,000$ \\
\hline
\end{tabular}

JOINT INTEREST OWNERS

Working Interest

\begin{tabular}{|c|c|c|c|}
\hline & Percent & Dry Hole $\$$ & Completed $\$$ \\
\hline & $93.000000 \%$ & $\$ 0$ & $\$ 1,350,360$ \\
\hline Others & $7.000000 \%$ & $\$ 48,650$ & $\$ 101,640$ \\
\hline AFE TOTAL: & $100.0000 \%$ & $\$ 48,650$ & $\$ 1,452,000$ \\
\hline
\end{tabular}

\begin{tabular}{|c|c|c|c|c|}
\hline \multicolumn{5}{|c|}{ INTERNAL RECOMMENDATION \& APPROVAL } \\
\hline Recommended: & & Approvals: & & \\
\hline Reservoir: & Date: & Eng / Prod'n Mgr: & & Date: \\
\hline Operations: & Date: & SVP Operations: & & Date: \\
\hline Geology: & Date: & SVP Asset Mgmt: & & Date: \\
\hline Land: & Date: & President: & & Date: \\
\hline Drilling: & Date: & CEO: & & Date: \\
\hline \multicolumn{5}{|c|}{ PARTNER APPROVAL } \\
\hline \multicolumn{5}{|l|}{ Company Name: } \\
\hline Authorized By: & & & Date: & \\
\hline Title: & & & & \\
\hline
\end{tabular}


DRILLING WELL COST ESTIMATE

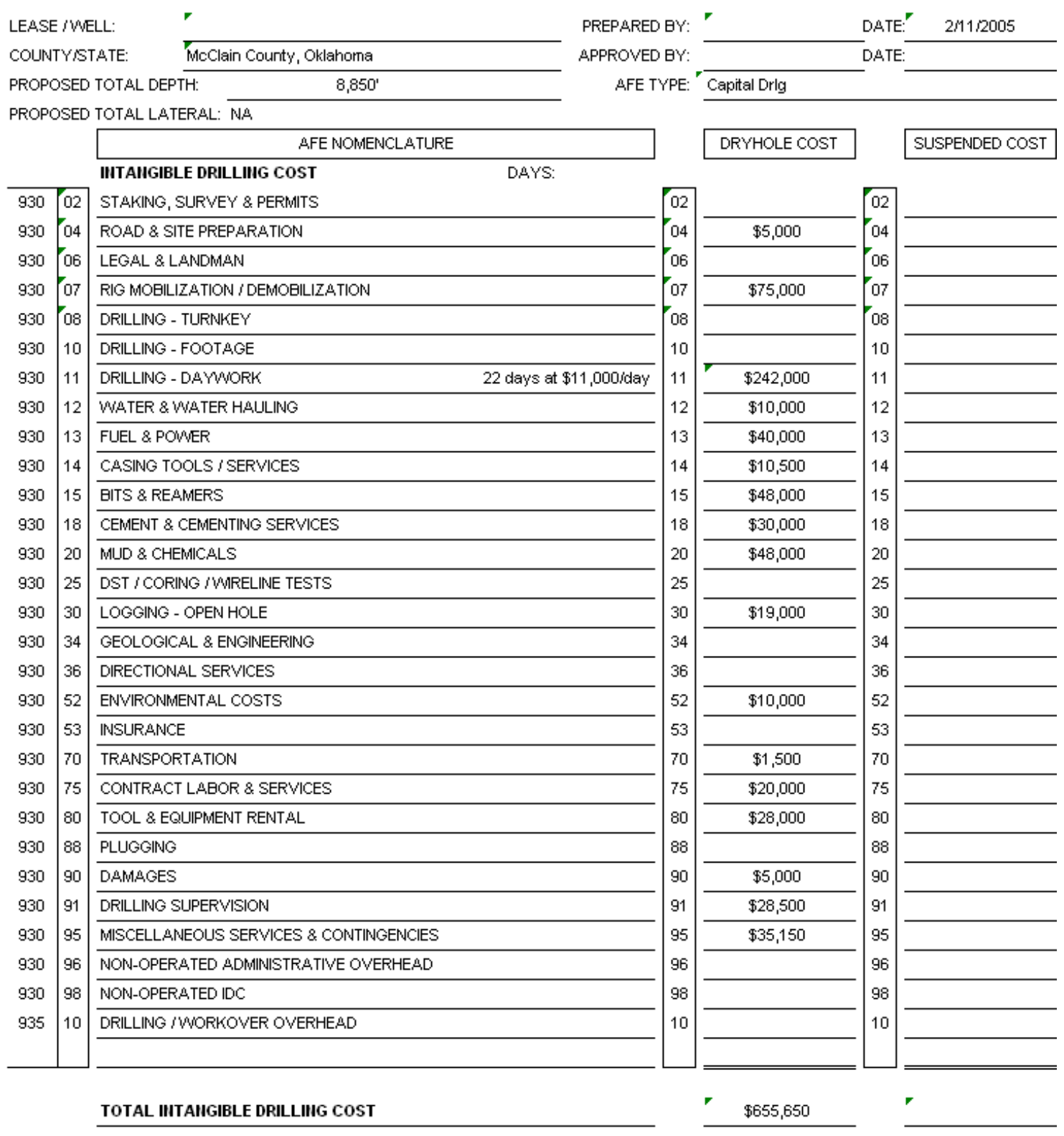

\section{TAIIGIBLE DRILLIIIG COST}

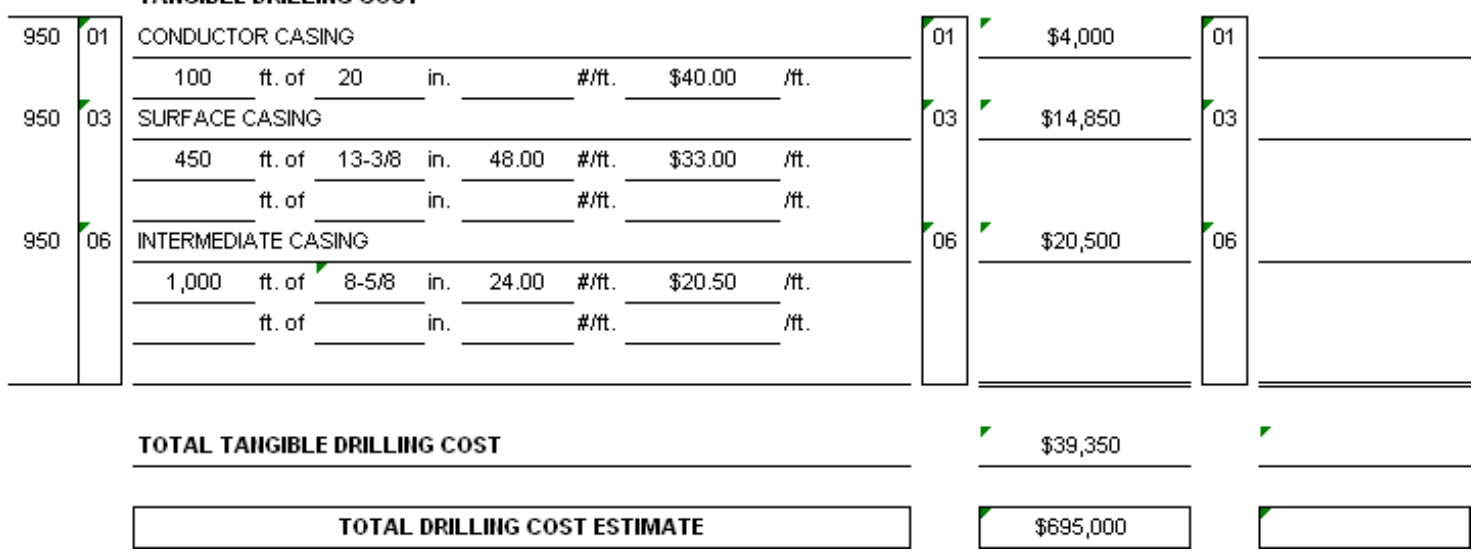


COMPLETION COST ESTIMATE

\begin{tabular}{|c|c|c|c|c|c|}
\hline \multicolumn{4}{|c|}{ LEASE /MELL: } & \multirow{3}{*}{$\begin{array}{r}\text { PREPARED BY: } \\
\text { APPROVED BY: } \\
\text { AFE TYPE: }\end{array}$} & \multirow{3}{*}{$\overline{6-\text { Dev }}$} \\
\hline \multicolumn{4}{|c|}{ LOCATION: } & & \\
\hline \multirow{3}{*}{\multicolumn{2}{|c|}{ COMPLETION FOF }} & DNFORMATIOA & Hart:Deese & & \\
\hline & & \multicolumn{4}{|c|}{ AFE NOMENCLATURE } \\
\hline & & \multicolumn{4}{|c|}{ IIITANGIBLE COMPLETION COSTS } \\
\hline 940 & 04 & \multicolumn{4}{|c|}{ SITE PREPARATION \& CLEAN UP } \\
\hline 940 & 10 & \multicolumn{3}{|c|}{ COMPLETION UNIT } & 9 days at $\$ 4,000$ /day \\
\hline 940 & 11 & \multicolumn{3}{|l|}{ DRILLING RIG } & 2 days at $\$ 11,000$ iday \\
\hline 940 & 12 & \multicolumn{4}{|c|}{ WATER \& WATER HAULING } \\
\hline 940 & 14 & \multicolumn{4}{|c|}{ CASING TOOLS / SERVICES } \\
\hline 940 & 15 & \multicolumn{4}{|c|}{ BITS \& REAMERS } \\
\hline 940 & 18 & \multicolumn{4}{|c|}{ CEMENT \& CEMENTING SERVICES - PRIMARY } \\
\hline 940 & 20 & \multicolumn{4}{|c|}{ DIRECTIONALAL SERVICES } \\
\hline 940 & 30 & \multicolumn{4}{|c|}{ LOGGING \& PERFORATING } \\
\hline 940 & 44 & \multicolumn{4}{|c|}{ ACIDIZING \& FRACTURING } \\
\hline 940 & 46 & \multicolumn{4}{|c|}{ PUMP TRUCK SERVICES } \\
\hline 940 & 47 & \multicolumn{4}{|c|}{ SAND CONTROL } \\
\hline 940 & 48 & \multicolumn{4}{|c|}{ SQUEEZE CEMENTING } \\
\hline 940 & 52 & \multicolumn{4}{|c|}{ ENVIRONMENTAL COSTS } \\
\hline 940 & 53 & \multicolumn{4}{|l|}{ INSURANCE } \\
\hline 940 & 70 & \multicolumn{4}{|c|}{ TRANSPORTATION } \\
\hline 940 & 75 & \multicolumn{4}{|c|}{ MIRELINE SERVICES } \\
\hline 940 & 80 & \multicolumn{4}{|c|}{ TOOL \& EQUIPMENT RENTAL } \\
\hline 940 & 85 & \multicolumn{4}{|c|}{ CONTRACT LABOR \& SERVICES } \\
\hline 940 & 92 & \multicolumn{4}{|c|}{ COMPLETION SUPERVISION } \\
\hline 940 & 95 & \multicolumn{4}{|c|}{ MISCELLANEOUS SERVICES \& CONTINGENCIES } \\
\hline 940 & 98 & \multicolumn{4}{|c|}{ NON-OPERATED ICC } \\
\hline
\end{tabular}

DATE: 2 211/2005 DATE (2) ESTIMATED COST

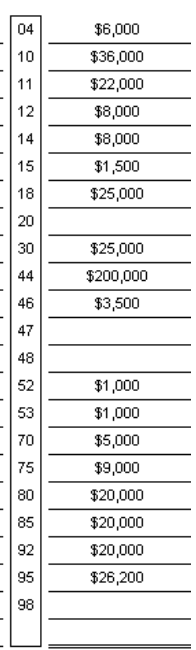

TOTAL IIITAIIGBELE COMPLETIOU COST

$\$ 437,200$ TAMGIBLE COMPLETIOH COST

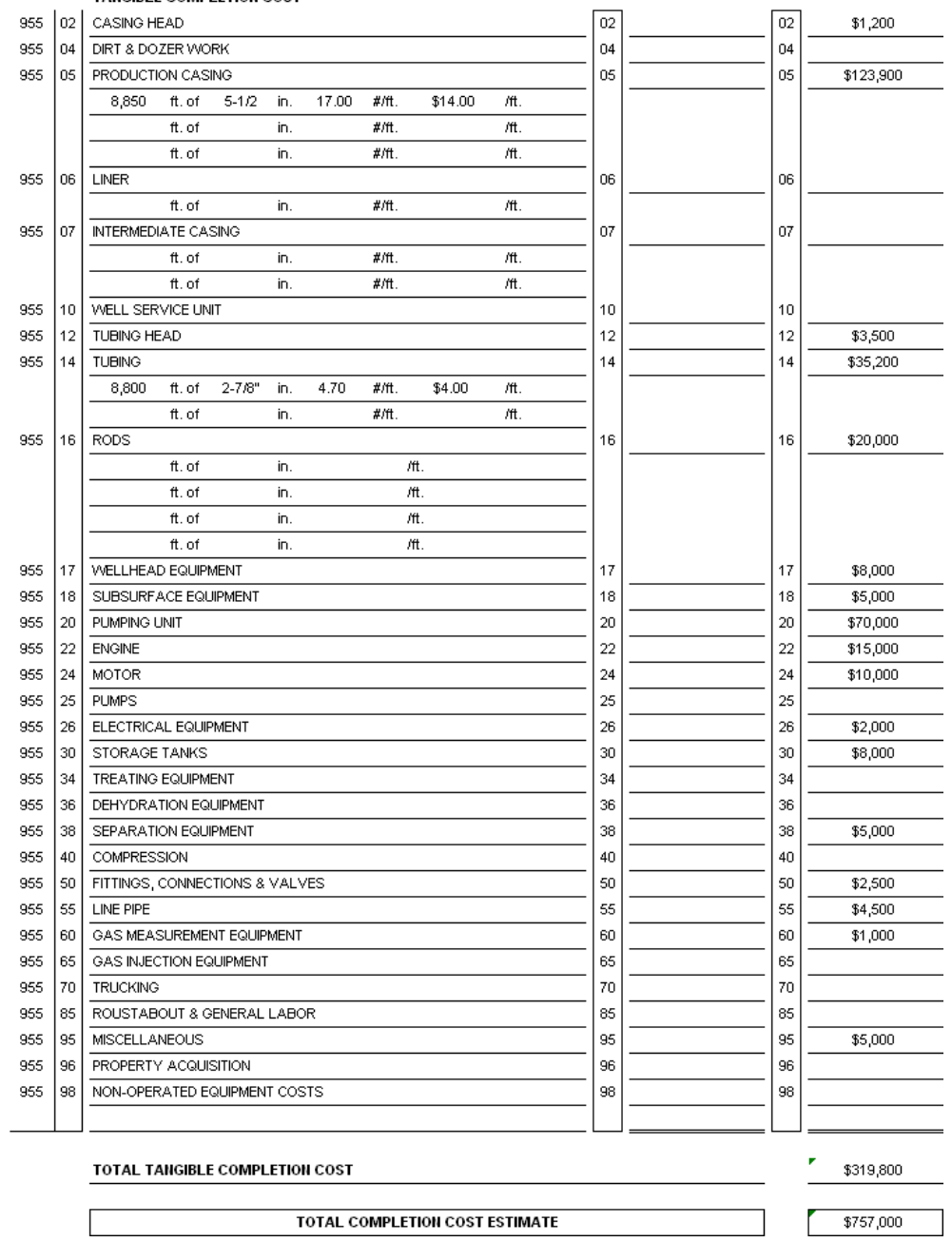


Location: Latimer Co., OK; Well Type: Gas-Directional Drill; Total Depth: 10,500 ft (3,200 m)

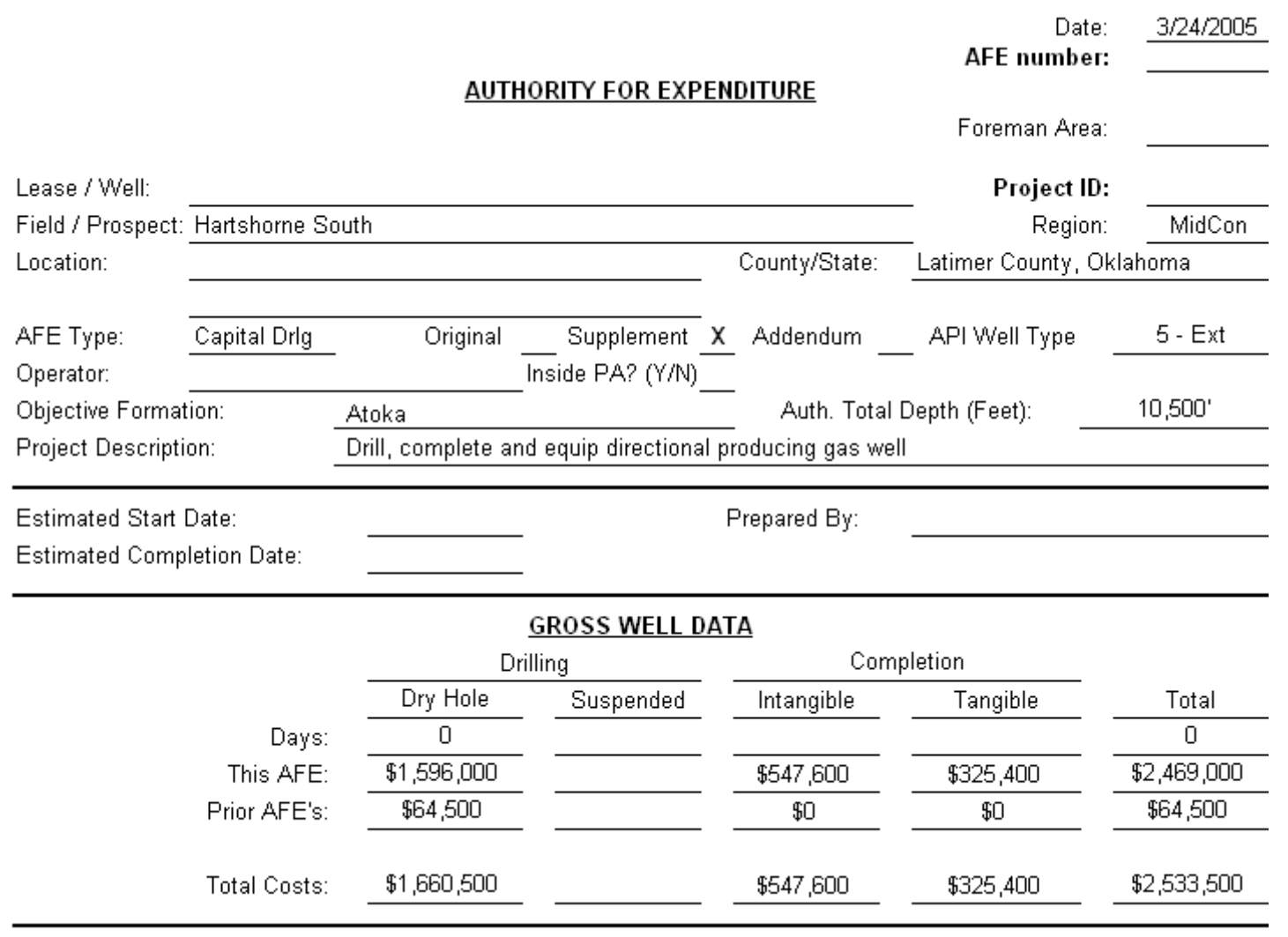

JOINT INTEREST OWNERS

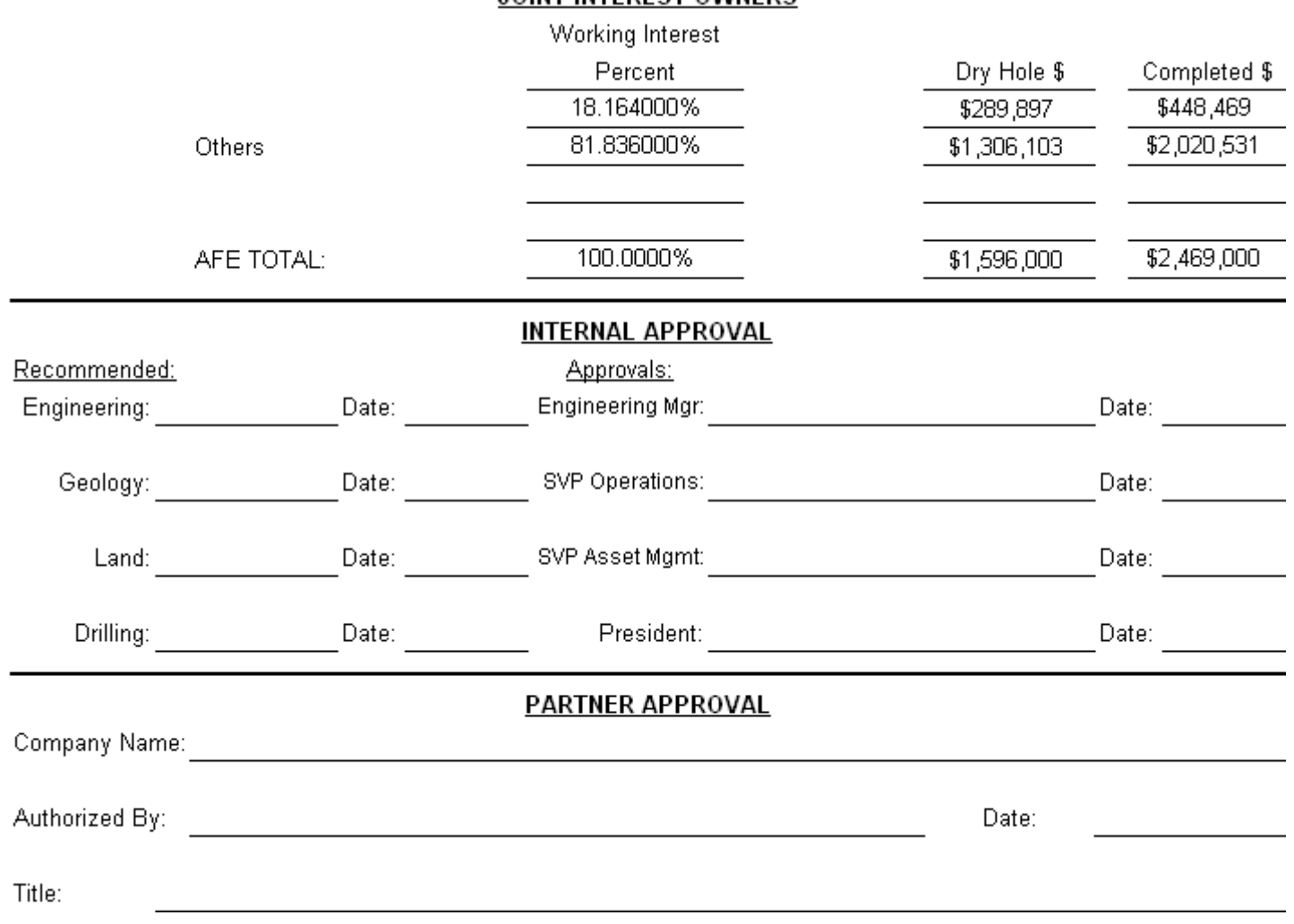


DRILLING WELL COST ESTIMATE

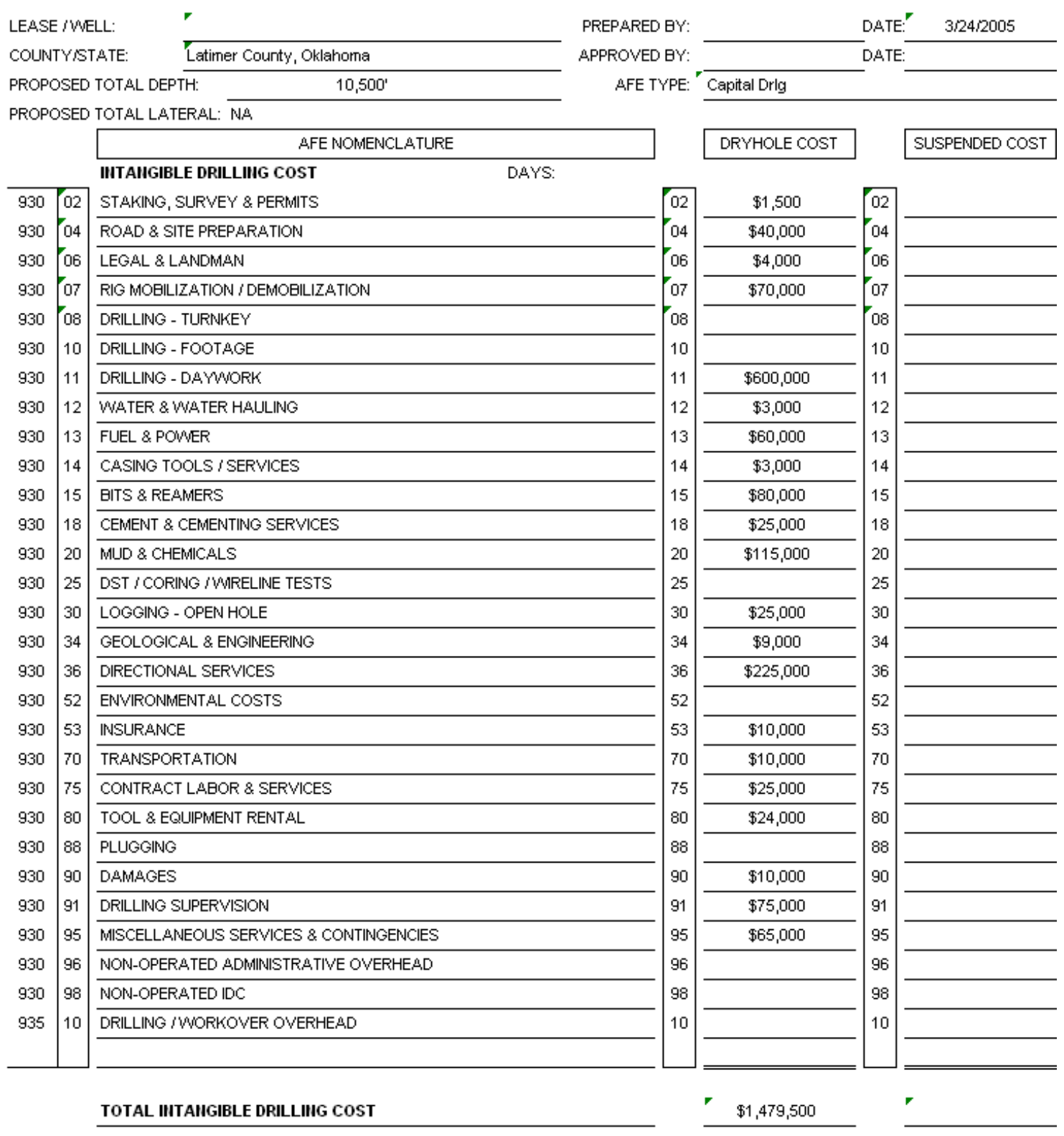

\section{TAIIGIBLE DRILLIIIG COST}

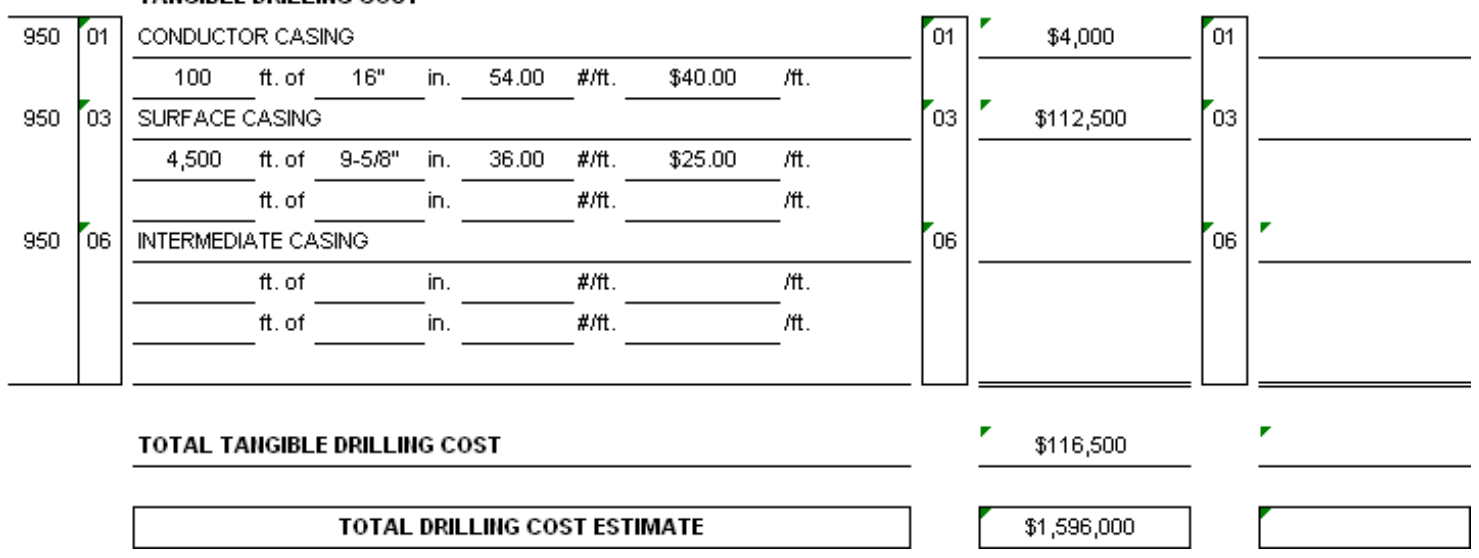


COMPLETION COST ESTIMATE

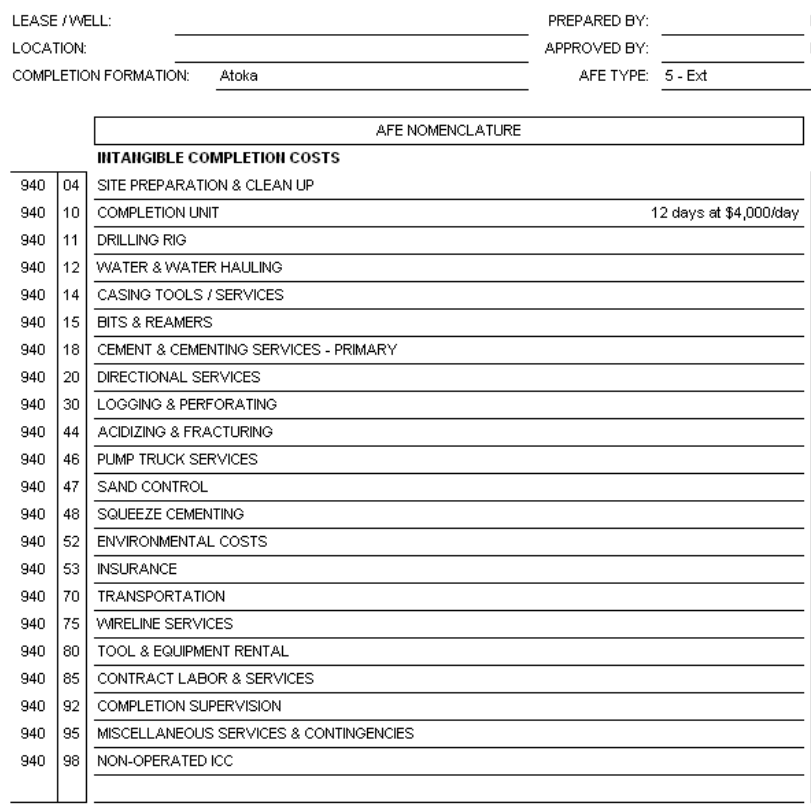

DATE: 3/24/2005 DATE (2)

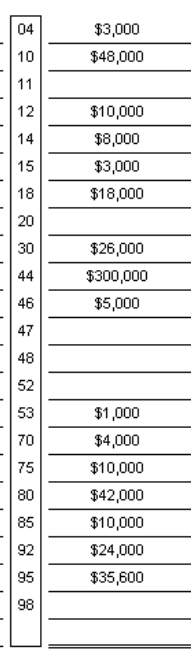

TOTAL IIITAIIGIBLE COMPLETIOII COST

$\$ 547,600$

TAIIGIBLE COMPLETION COST

\begin{tabular}{|c|c|c|c|c|c|c|c|c|c|}
\hline 955 & 02 & CASING & & & & & & & \\
\hline 955 & 04 & DIRT \& DC & ZER WO & & & & & & \\
\hline 955 & 05 & PRODUCT & ON CAS & & & & & & \\
\hline & & 14,000 & ft. of & $5-1 / 2^{\prime \prime}$ & in. & 17.00 & \#/fit. & $\$ 16.00$ & ift. \\
\hline & & & ft. of & & in. & & \#/fit. & & ift. \\
\hline & & & $\mathrm{ft}$. of & & in. & & \#/fit. & & ift. \\
\hline 955 & 06 & LINER & & & & & & & \\
\hline & & & $\mathrm{ft}$. of & & in. & & \#/fit. & & ift. \\
\hline 955 & 07 & INTERMED & ATE CA & & & & & & \\
\hline & & & ft. of & & in. & & \#/ft. & & ift. \\
\hline & & & $\mathrm{ftt}$ of & & in. & & \#/fit. & & ift. \\
\hline 955 & 10 & WELL SEF & VICE UN & & & & & & \\
\hline 955 & 12 & TUBING H & & & & & & & \\
\hline 955 & 14 & TUEING & & & & & & & \\
\hline & & 10,000 & ft. of & $2-3 / 8 "$ & in. & 4.70 & \#/ft. & $\$ 4.50$ & ift. \\
\hline & & & ft. of & & in. & & \#/ft. & & ift. \\
\hline 955 & 16 & RODS & & & & & & & \\
\hline & & & ft. of & & in. & & it & & \\
\hline & & & ft. of & & in. & & it & & \\
\hline & & & ft. of & & in. & & it & & \\
\hline & & & ft. of & & in. & & it & & \\
\hline 955 & \begin{tabular}{l|l|}
5 & 17
\end{tabular} & MELLHEA & EQUIPI & MENT & & & & & \\
\hline 955 & 18 & SUBSURF & $\mathrm{ACE} E \mathrm{EQL}$ & IIPMENT & & & & & \\
\hline 955 & 520 & PUMPING & & & & & & & \\
\hline 955 & 522 & ENGINE & & & & & & & \\
\hline 955 & 524 & MOTOR & & & & & & & \\
\hline 955 & $5 \mid 25$ & PUMPS & & & & & & & \\
\hline 955 & 526 & $\overline{\text { ELECTRIC }}$ & LL EQUIF & PMENT & & & & & \\
\hline 955 & 530 & STORAGE & TANKS & & & & & & \\
\hline 955 & 34 & $\overline{T R E A T I N C}$ & EQUPMM & & & & & & \\
\hline 955 & \begin{tabular}{|l|l|}
5 & 36
\end{tabular} & DEHYDRA & TIONEQ & UIPMENT & & & & & \\
\hline 955 & 538 & SEPARAT & ON EQUII & IPMENT & & & & & \\
\hline 955 & \begin{tabular}{l|l}
5 & 40
\end{tabular} & COMPRES & SION & & & & & & \\
\hline 955 & 550 & FITTINGS, & CONNEC & TIONS \& & VALV & & & & \\
\hline 955 & 55 & LINE PIPE & & & & & & & \\
\hline 955 & 560 & GAS MEA & SUREMEI & NT EQUIPI & PMENT & & & & \\
\hline 955 & 65 & GAS IN JE & CTION EG & QUIPMENT & & & & & \\
\hline 955 & 50 & TRUCKINC & & & & & & & \\
\hline 955 & 85 & ROUSTAE & OUT \& $\mathrm{G}$ & ENERAL & LABO & & & & \\
\hline 955 & 95 & MISCELLA & NEOUS & & & & & & \\
\hline 955 & 596 & PROPERT & ACQUI: & SITION & & & & & \\
\hline 955 & 98 & NON-OPE & RATED E & QUIPMENT & it $\cos$ & & & & \\
\hline
\end{tabular}

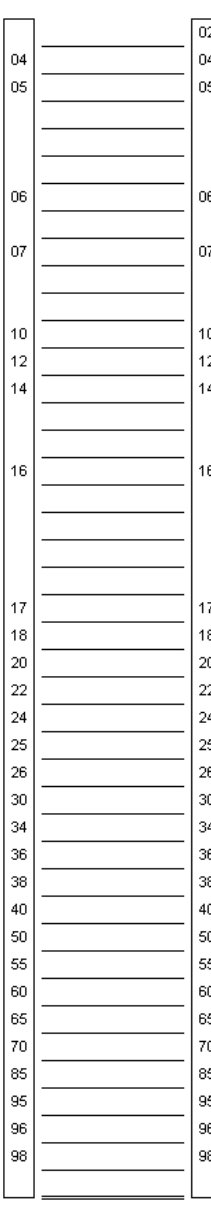

TOTAL TAIIGIBLE COMPLETIOI $\cos$

TOTAL COMPLETIOII COST ESTIMATE

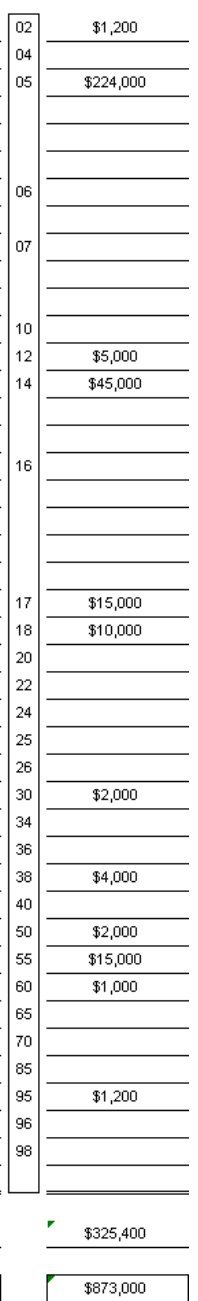




\section{Location: Smith Co., TX (Dist. 6); Well Type: Gas; Total Depth: 11,950 ft (3,642 m)}

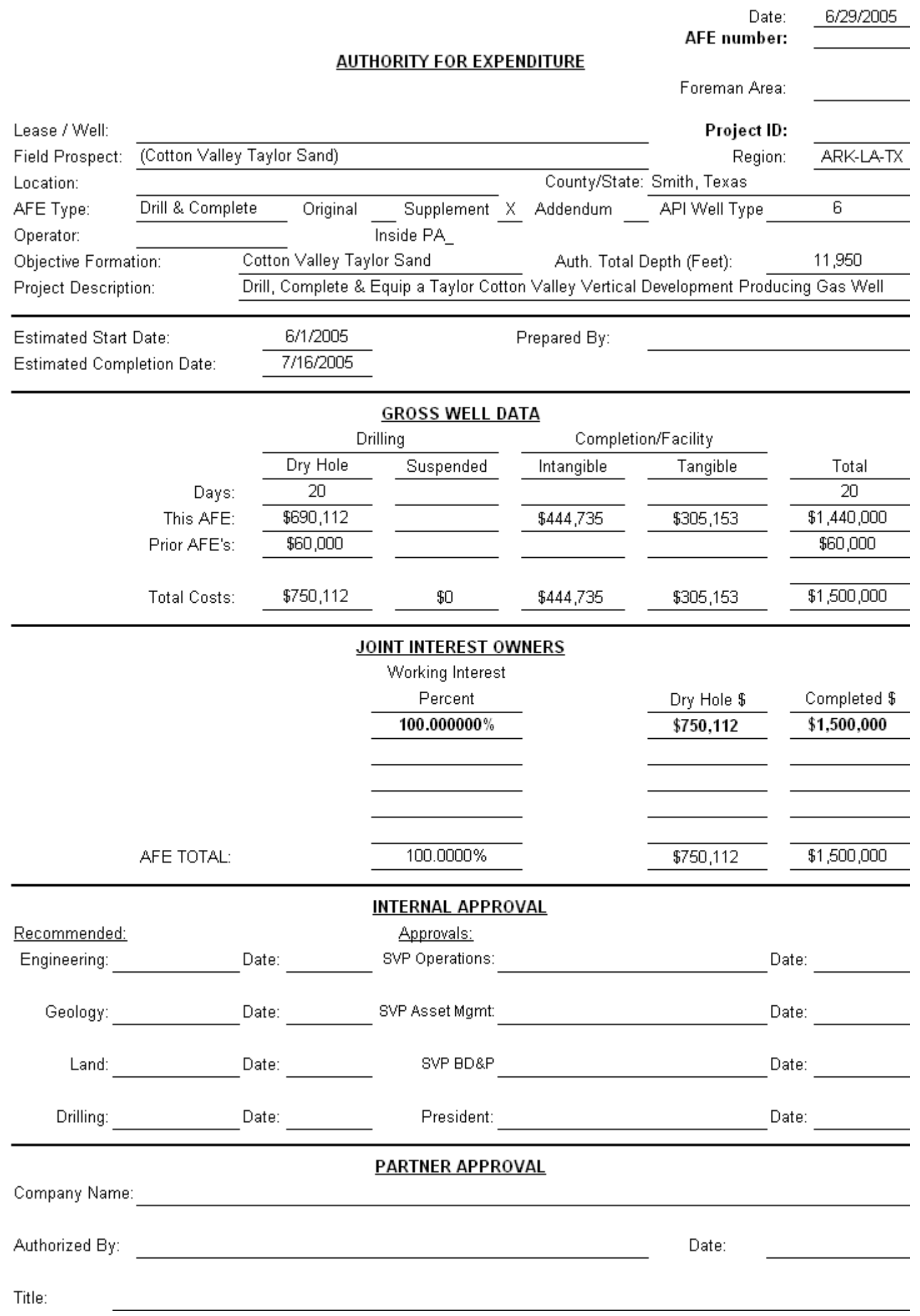


DRILLING WELL COST ESTIMATE

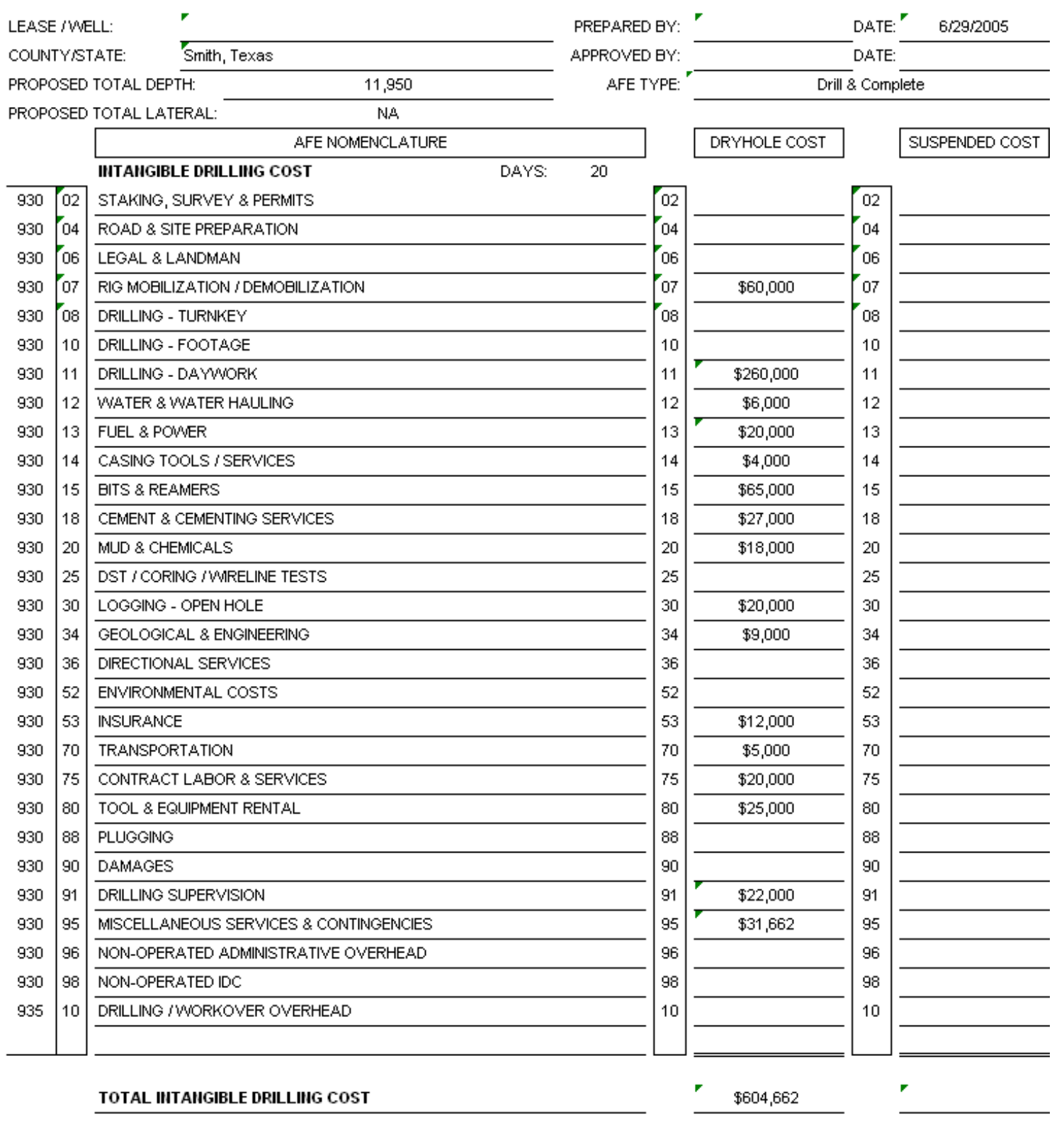

TAIIGIBLE DRILLIIIG CosT

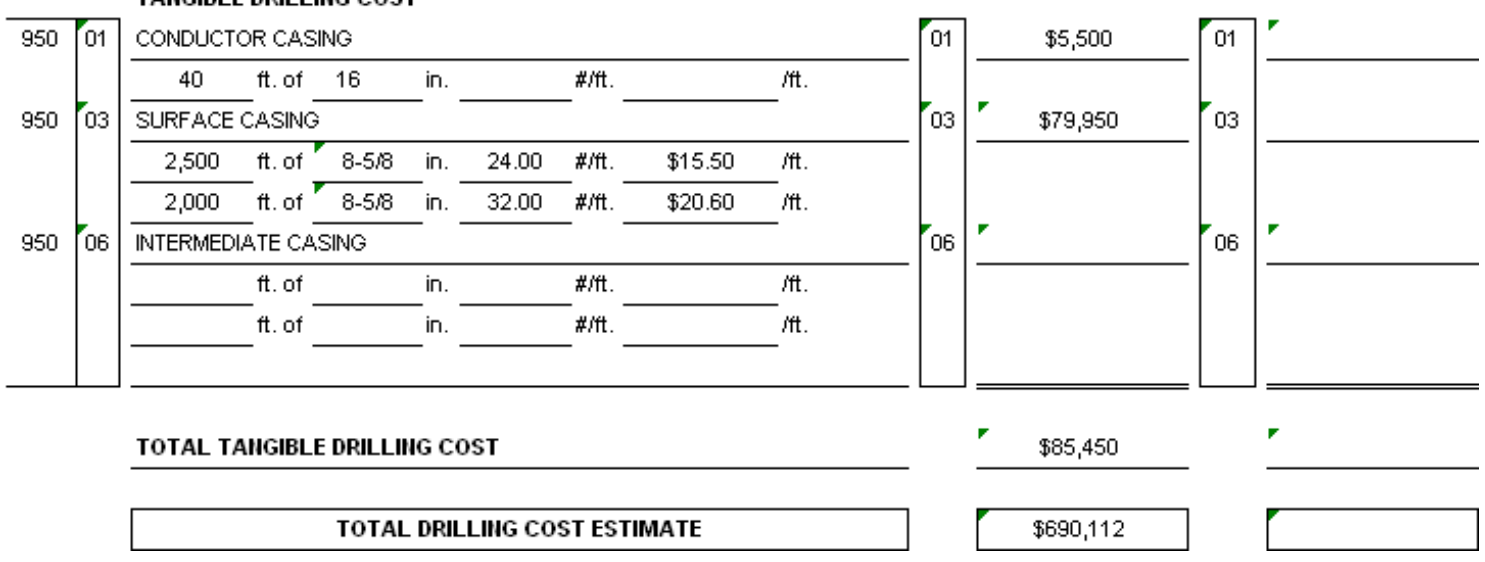


COMPLETION COST ESTIMATE

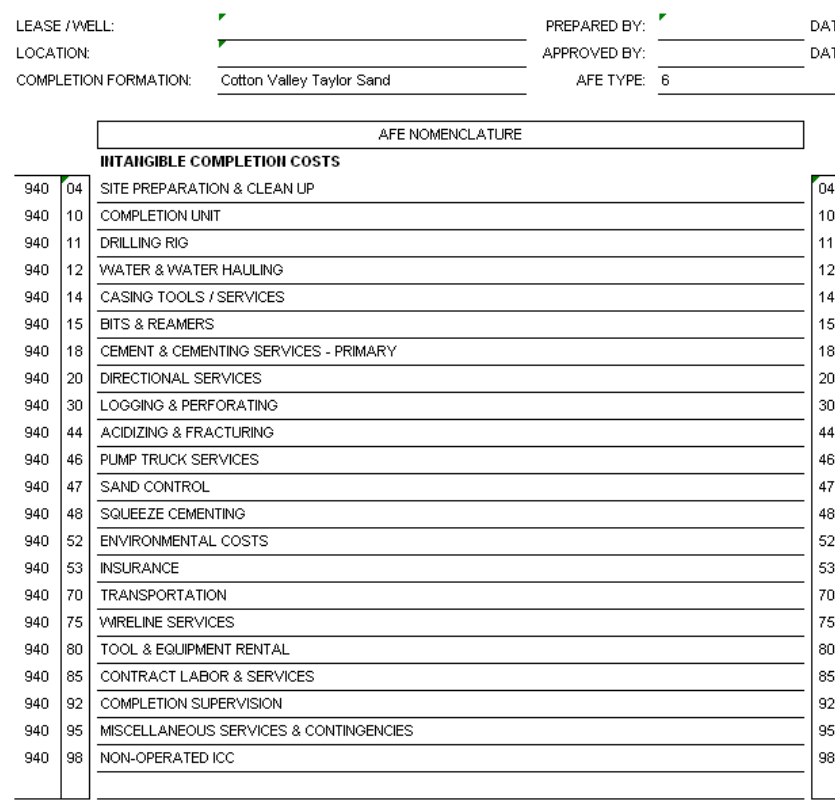

TOTAL III AIIGGBLE COMPLETIOI COST

ESTIMATED COST

TAIGIBLE COMPLETIOI COST

955 Po2 TAIIGLE COMP

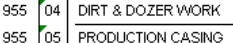

O5 PRODUCTION CASING

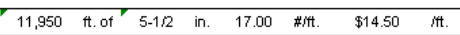

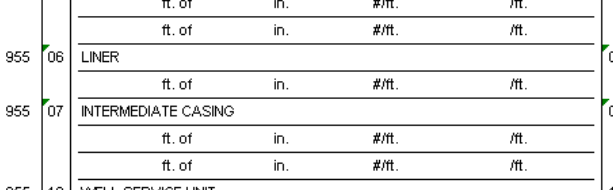

95510 MELL SERVICE UNIT

95512 TUEING HEAD

95514 TUEING

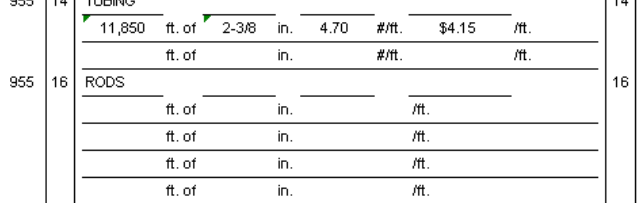

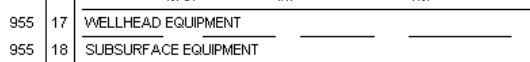

95520 PUMPING UNIT

95522 ENGINE

95524 MOTOR

95525 PUMPS

95526 ELECTRICAL EQUIPMENT

95530 STORAGE TANKS

95534 TREATING EQUIPMENT

95536 DEHYDRATION EQUIPMENT

95538 SEPARATION EQUIPMENT

95540 COMPRESSION

95550 FITTINGS, CONNECTIONS \& VALVES

95555 LINE PIPE

95560 GAS MEASUREMENT EQUIPMENT

95565 GAS INJECTION EQUIPMENT

95570 TRUCKING

95585 ROUSTABOUT \& GENERAL LABOR

95595 MISCELLANEOUS

95596 PROPERTY ACQUIIITION

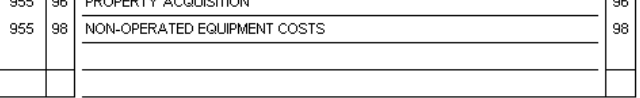

TOTAL TAIGGBLE COMPLETIOI COST

PRODUCTION COST

$\$ 444,735$

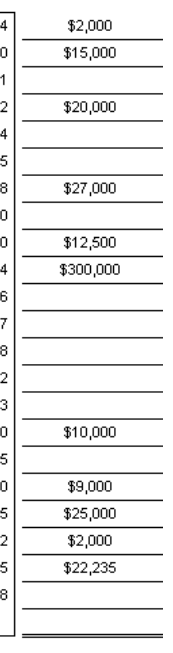

FACLIITY COST

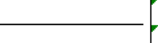

02

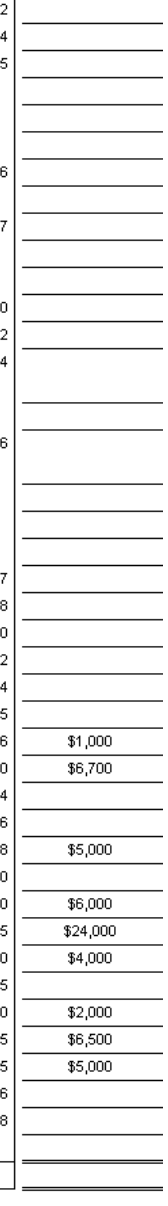

$\$ 244,953$

$\$ 60,200$

TOTAL COMPLETIOII COST ESTIMATE 
Location: Roger Mills Co., OK; Well Type: Gas; Total Depth: 12,705 ft (3,872 m)

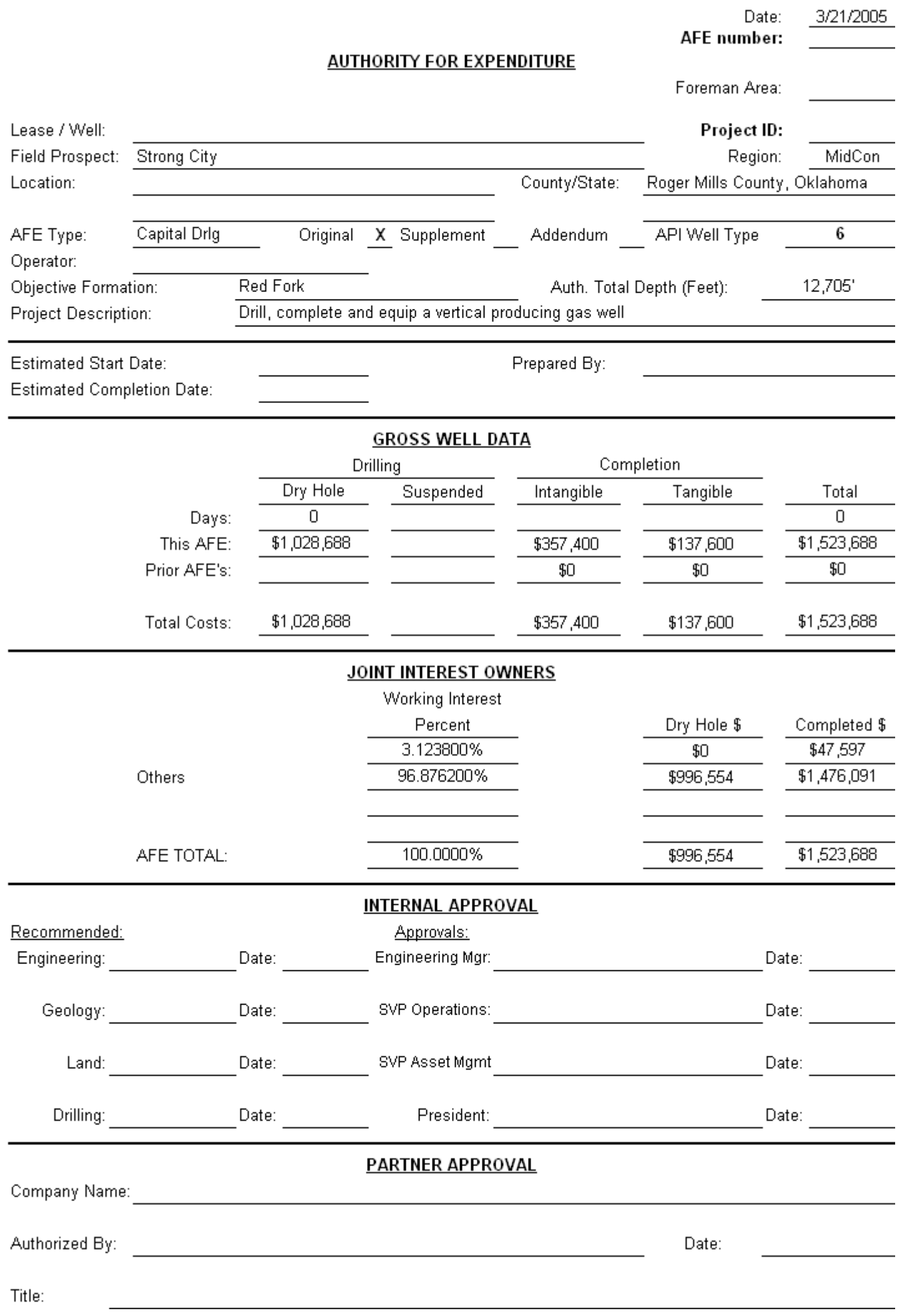


DRILLING WELL COST ESTIMATE

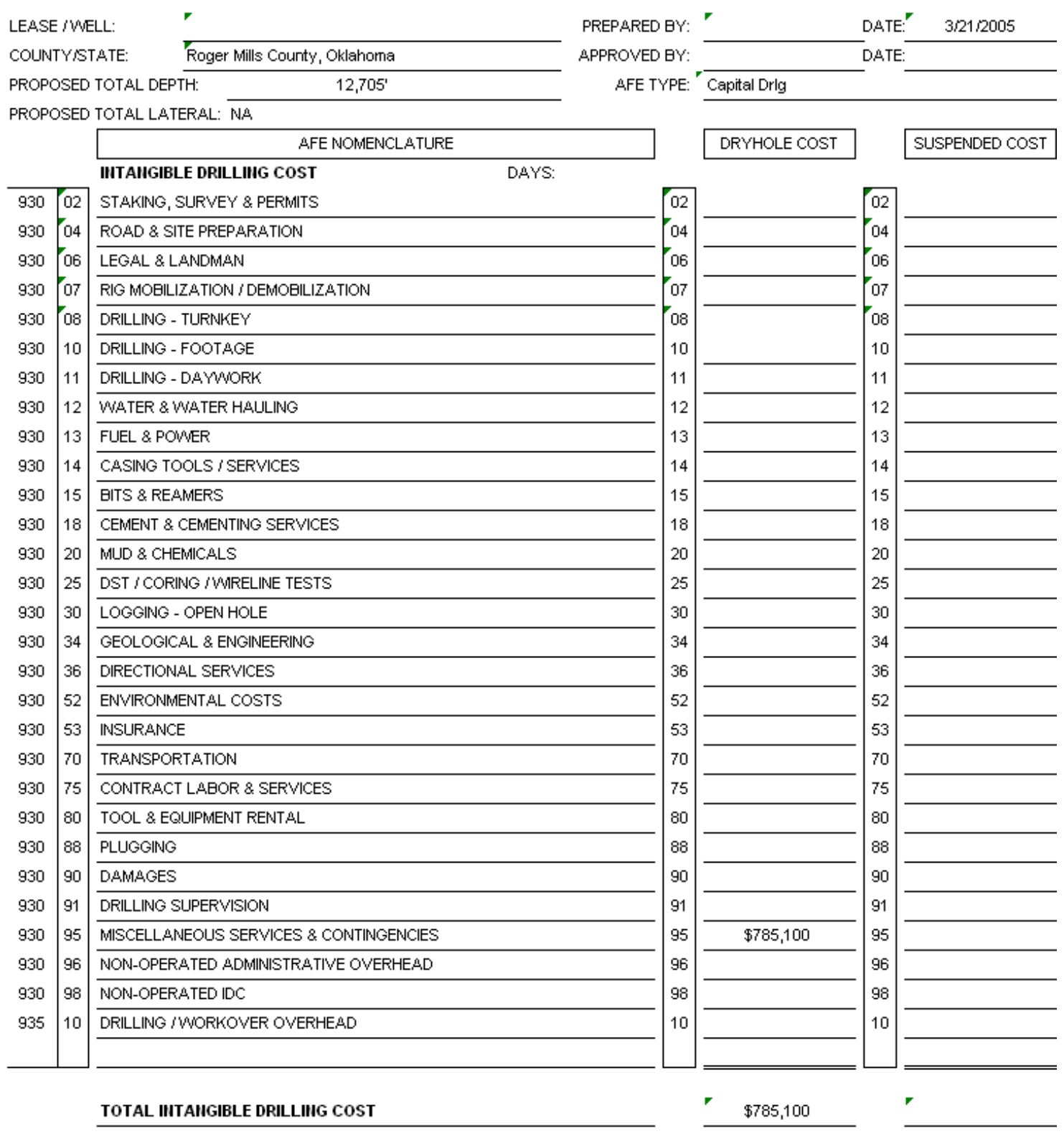

TAIIGIBLE DRILLIIIG COST

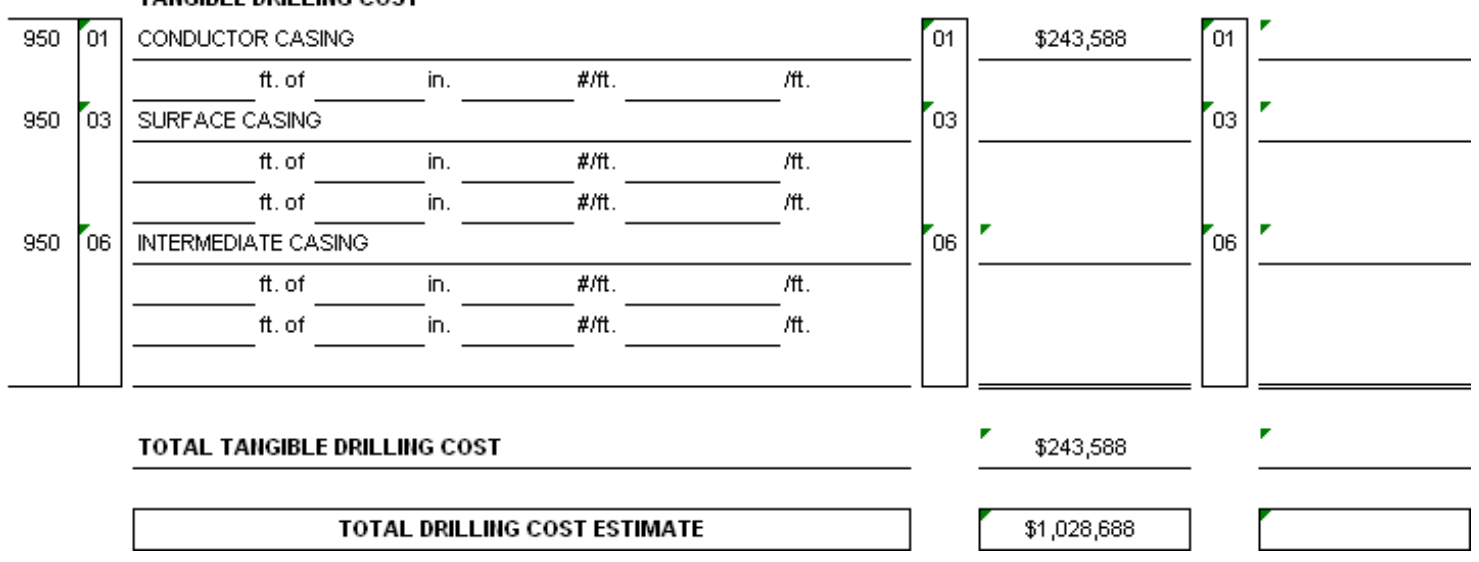


COMPLETION COST ESTIMATE

\begin{tabular}{|c|c|c|c|c|c|}
\hline LEASE & ME & & & PREPARED BY: & \\
\hline LOCATI & & & & & \\
\hline COMPLE & ETIOI & ON FORMATION: & Red Fork & AFE TYPE: & 6 \\
\hline & & & AFE NO & & \\
\hline & & IIITANGIBLE C & MPLETIOH COSTS & & \\
\hline 940 & 04 & SITE PREPARA & ION \& CLEAN UP & & \\
\hline 940 & 10 & COMPLETIONI & & & \\
\hline 940 & 11 & DRILLING RIG & & & \\
\hline 940 & 12 & WATER \& WA & R HAULING & & \\
\hline 940 & 14 & CASING TOOL & ISERVICES & & \\
\hline 940 & 15 & BITS \& REAME & & & \\
\hline 940 & 18 & CEMENT \& CEN & NTING SERVICES - PRIMARY & & \\
\hline 940 & 20 & DIRECTIONAL & ERVICES & & \\
\hline 940 & 30 & LOGGING \& PE & FORATING & & \\
\hline 940 & 44 & ACIDIZING \& F & ACTURING & & \\
\hline 940 & 46 & PUMP TRUCK & RVICES & & \\
\hline 940 & 47 & SAND CONTR & & & \\
\hline 940 & 48 & SQUEEEZE CEM & NTING & & \\
\hline 940 & 52 & ENVIRONMENT & L COSTS & & \\
\hline 940 & 53 & INSURANCE & & & \\
\hline 940 & 70 & TRANSPORTA & & & \\
\hline 940 & 75 & MARELINE SER & & & \\
\hline 940 & 80 & TOOL \& EQUIP & ENT RENTAL & & \\
\hline 940 & 85 & CONTRACT LA & IOR \& SERVICES & & \\
\hline 940 & 92 & COMPLETION & IPERVISION & & \\
\hline 940 & 95 & MISCELLANEO & S SERVICES \& CONTINGENCIES & & \\
\hline 940 & 98 & NON-OPERATE & & & \\
\hline
\end{tabular}

DATE: 3/21/2005

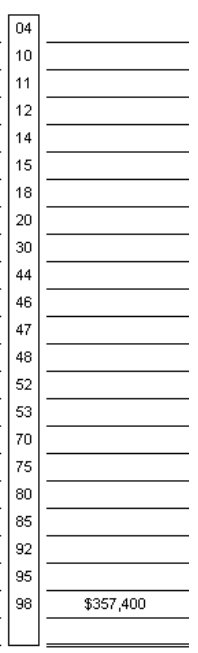

TOTAL IITAAIIGLLE COMPLETIOI COST

TAMGIBLE COMPLETIOH COST

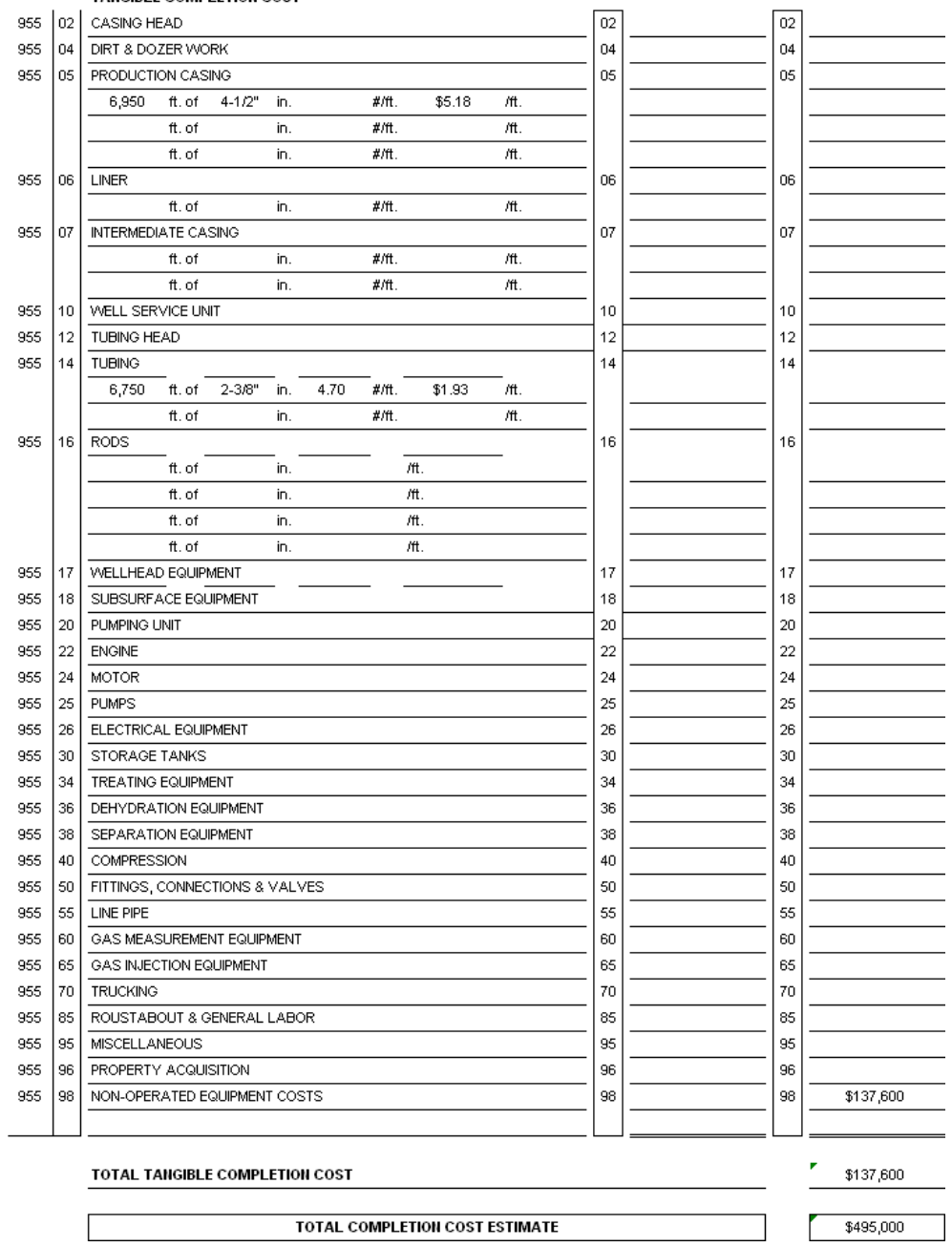




\section{Location: Dawson Co., MT; Well Type: Gas-Dual Lateral Completion; Depth: TVD -9,150 ft, KOP -8,600 ft, Total Depth $-13,200 \mathrm{ft}(4,023 \mathrm{~m})$}

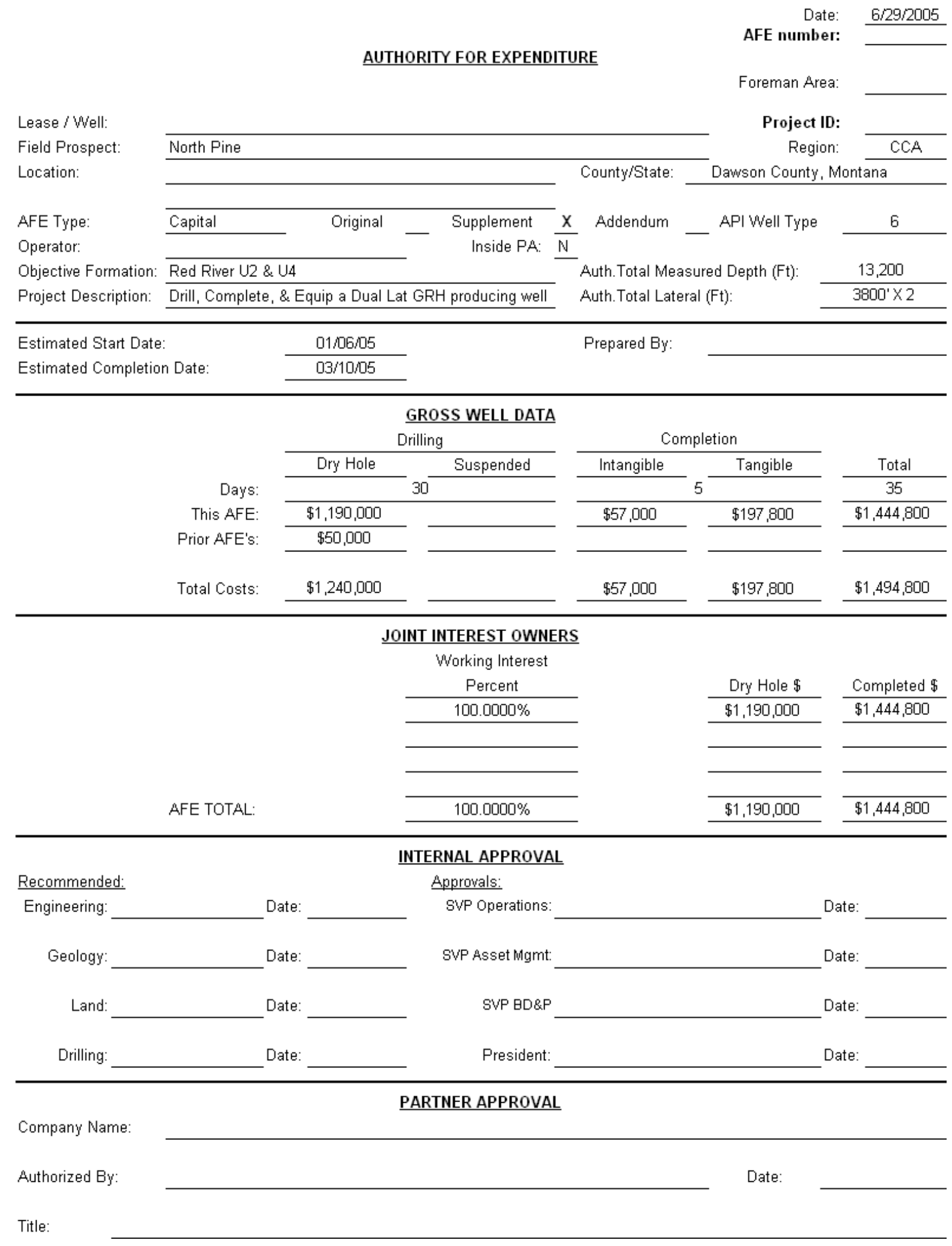


DRILLING WELL COST ESTIMATE

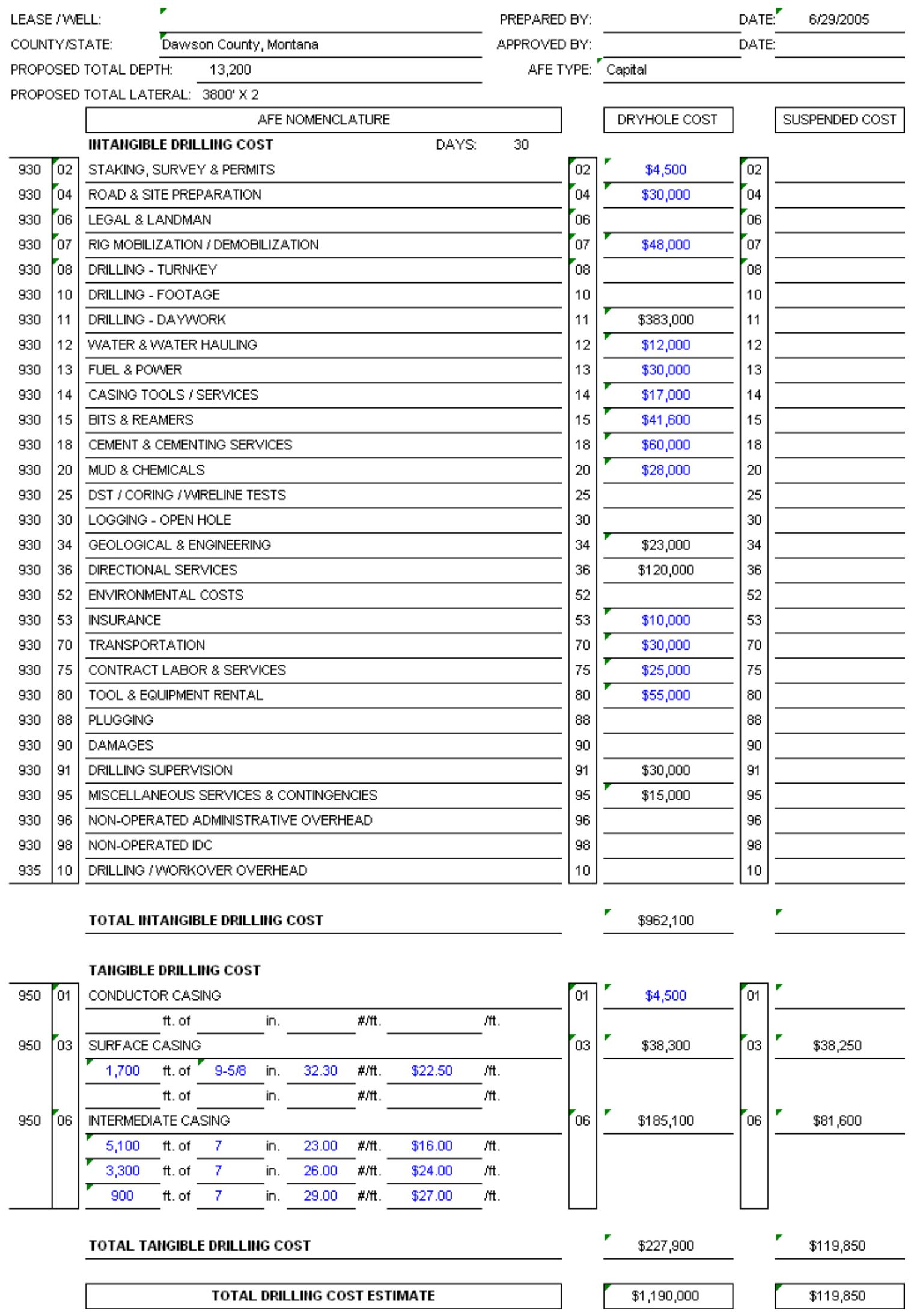


COMPLETION COST ESTIMATE

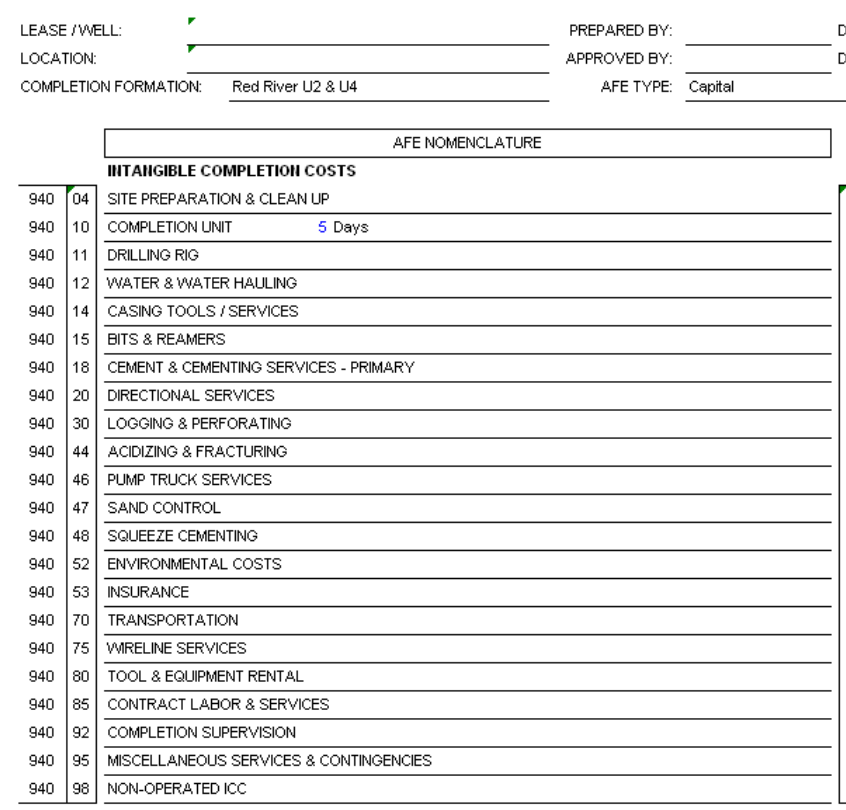

DATE: 6:29/2005 DATE:

TAGE COMPLETIOH COSTS

\section{$\$ 2,000$}

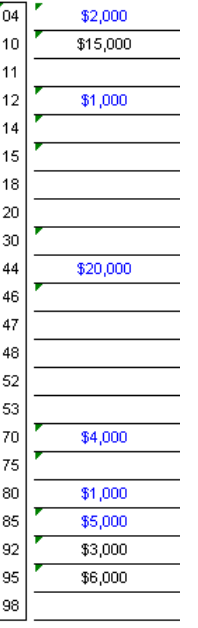

TOTAL IITANGIBLE COMPLETIOI COST

\section{TAUGIBLE COMPLETION COST}
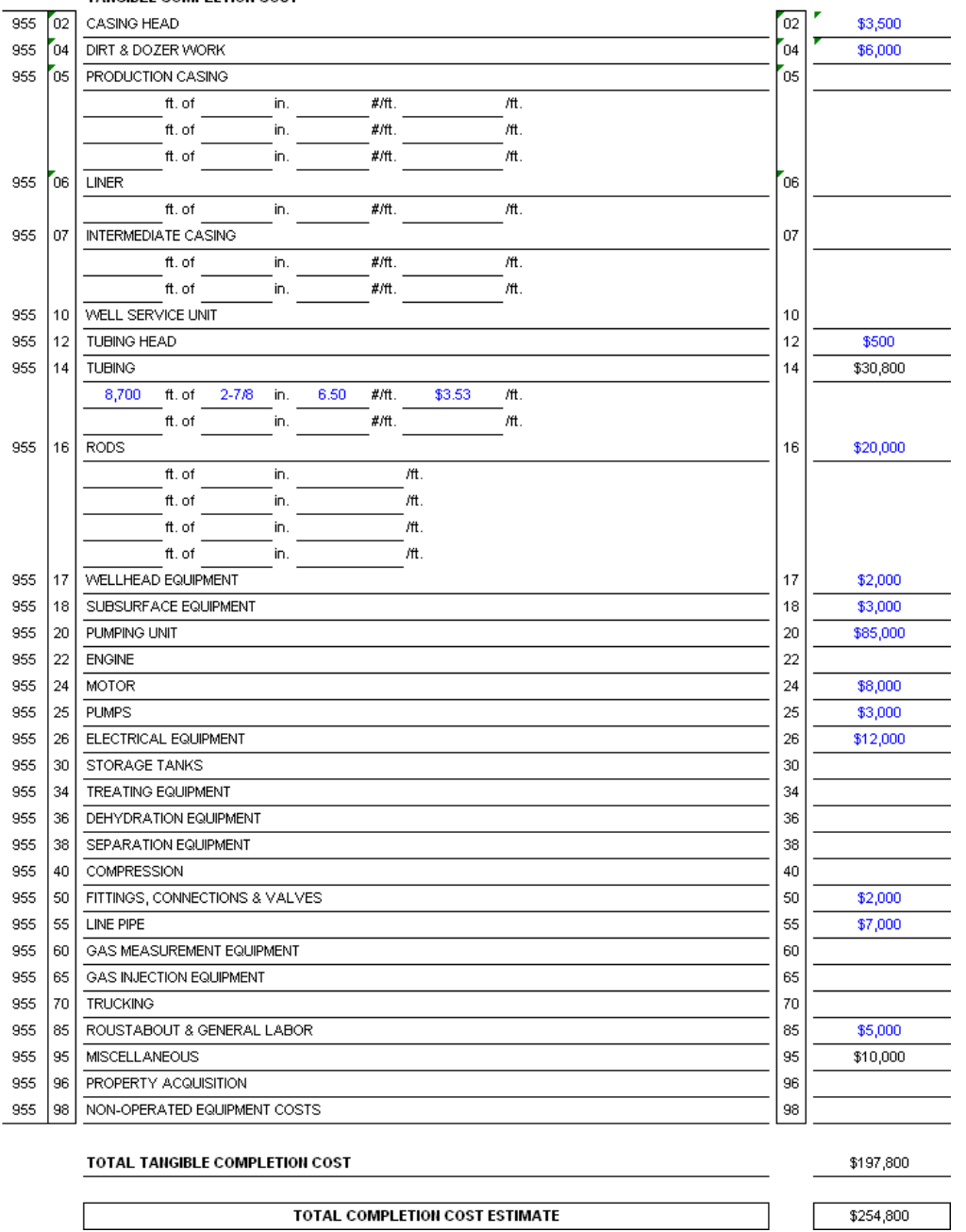


\title{
Appendix B
}

\section{Drilling Cost versus Depth Curves}

\author{
Total range of depth (feet) \\ 0 - 8000 (feet) \\ $8000-20000$ (feet) \\ Polynomial Curve Fitting Plots ............... 43 \\ Exponential Curve Fitting Plots ............. 58 \\ Power Series Curve Fitting Plots............ 77
}




\section{Polynomial Curve Fitting Plots}

\section{Polynomial Curve Fit for All Wells Surveyed}
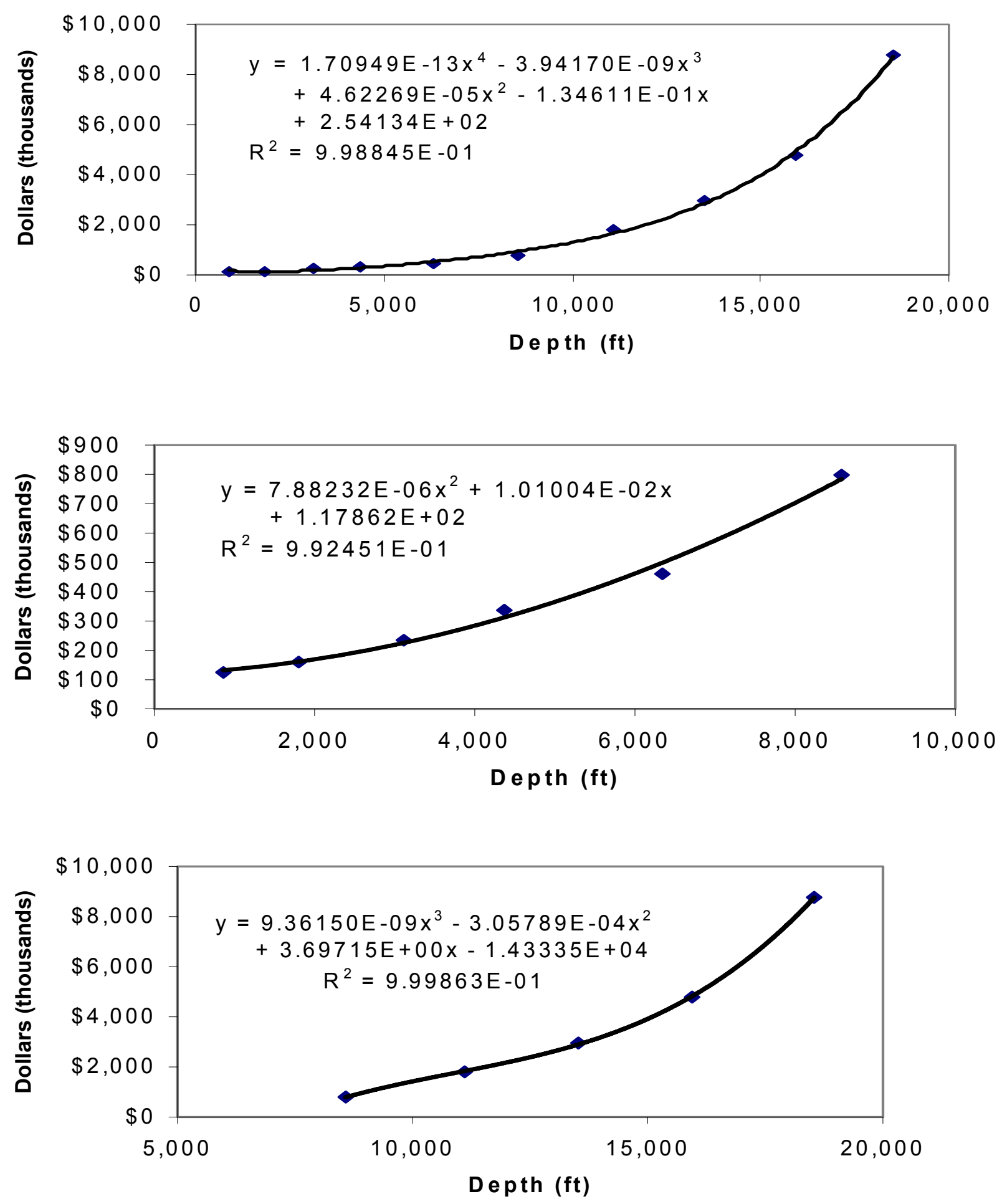


\section{Western United States}

\section{Total Western States Wells Surveyed}
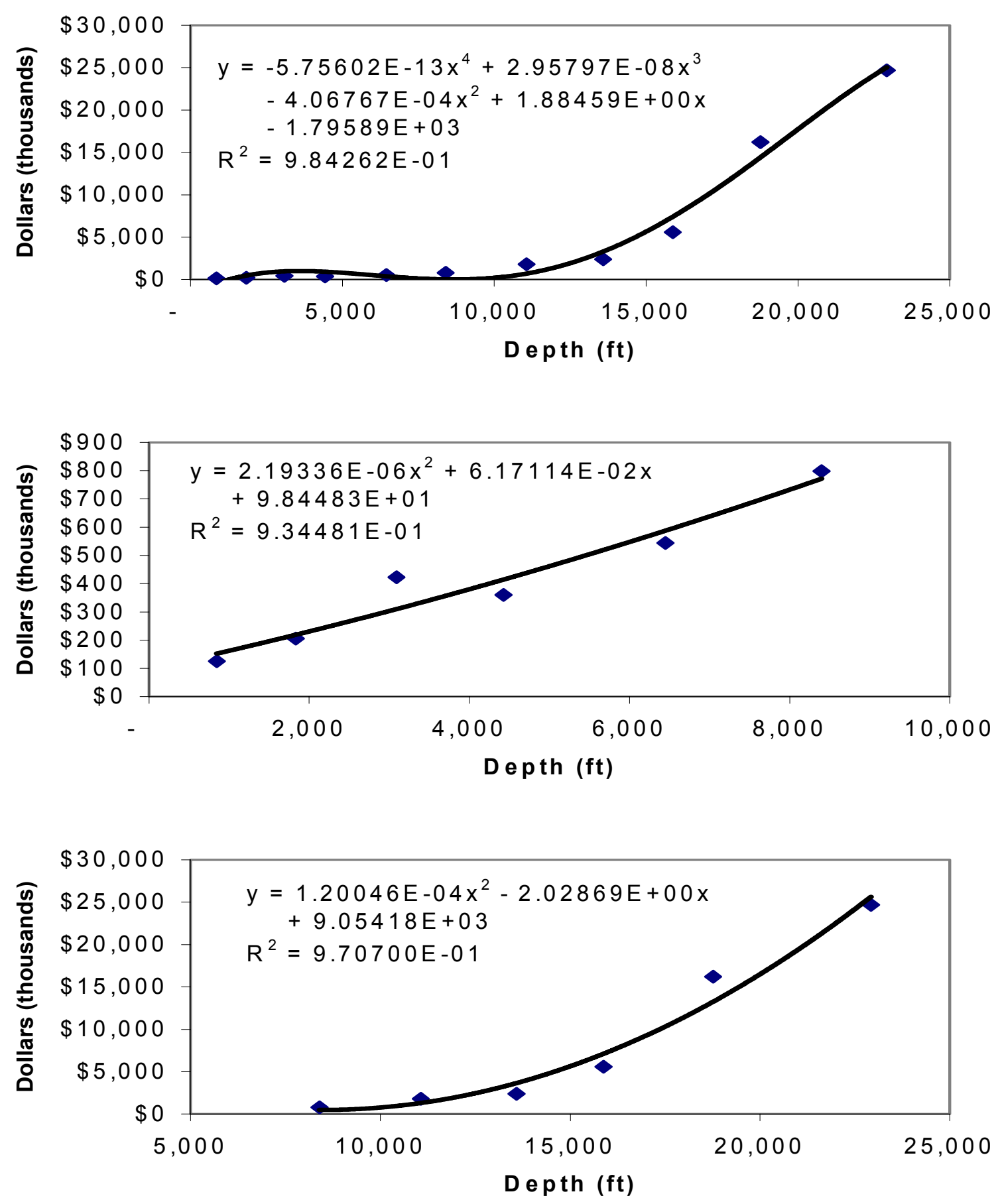


\section{Southeastern United States}

\section{Texas Districts 2, 3, and 4}
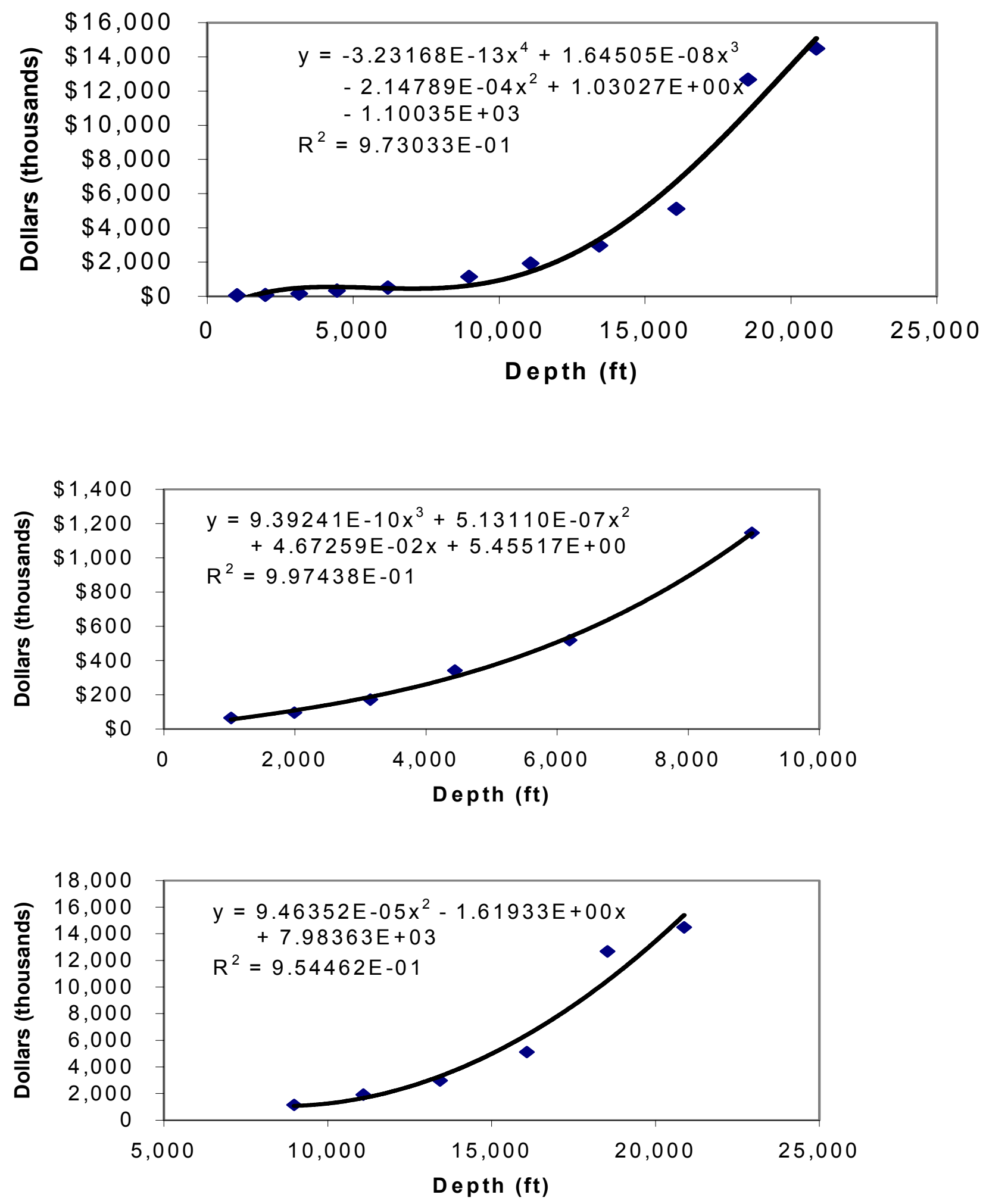


\section{California Onshore}
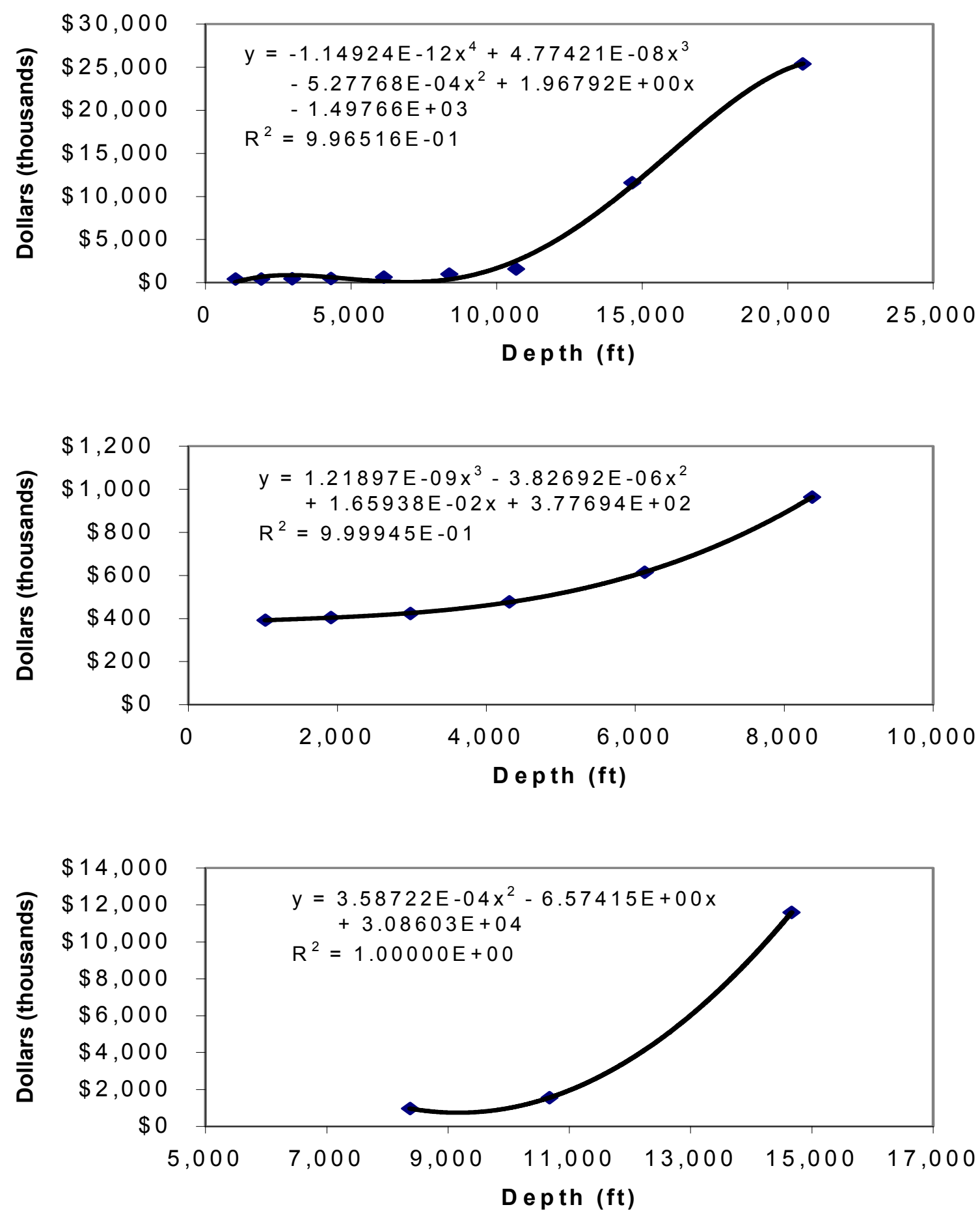


\section{Colorado}
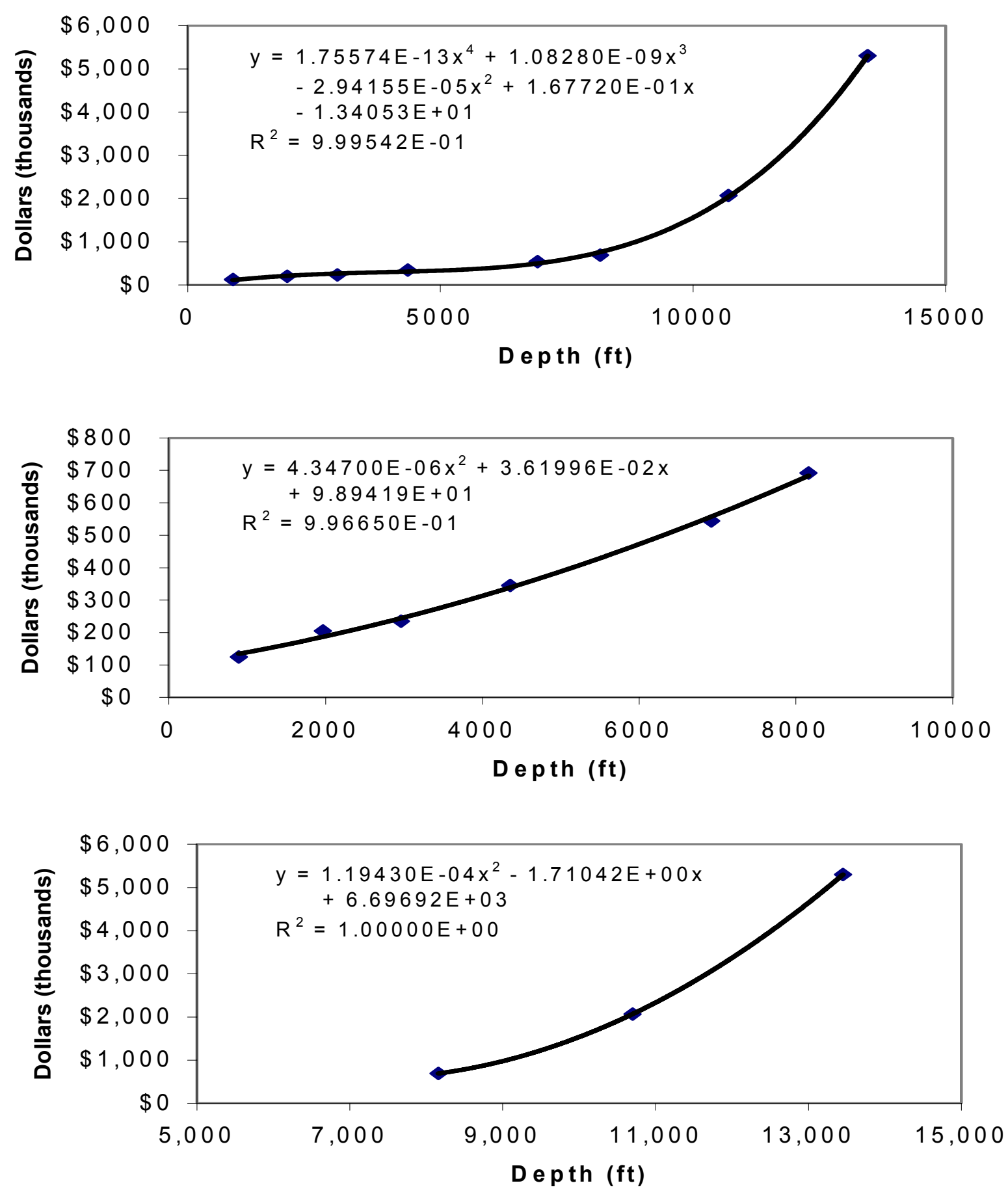


\section{Montana}
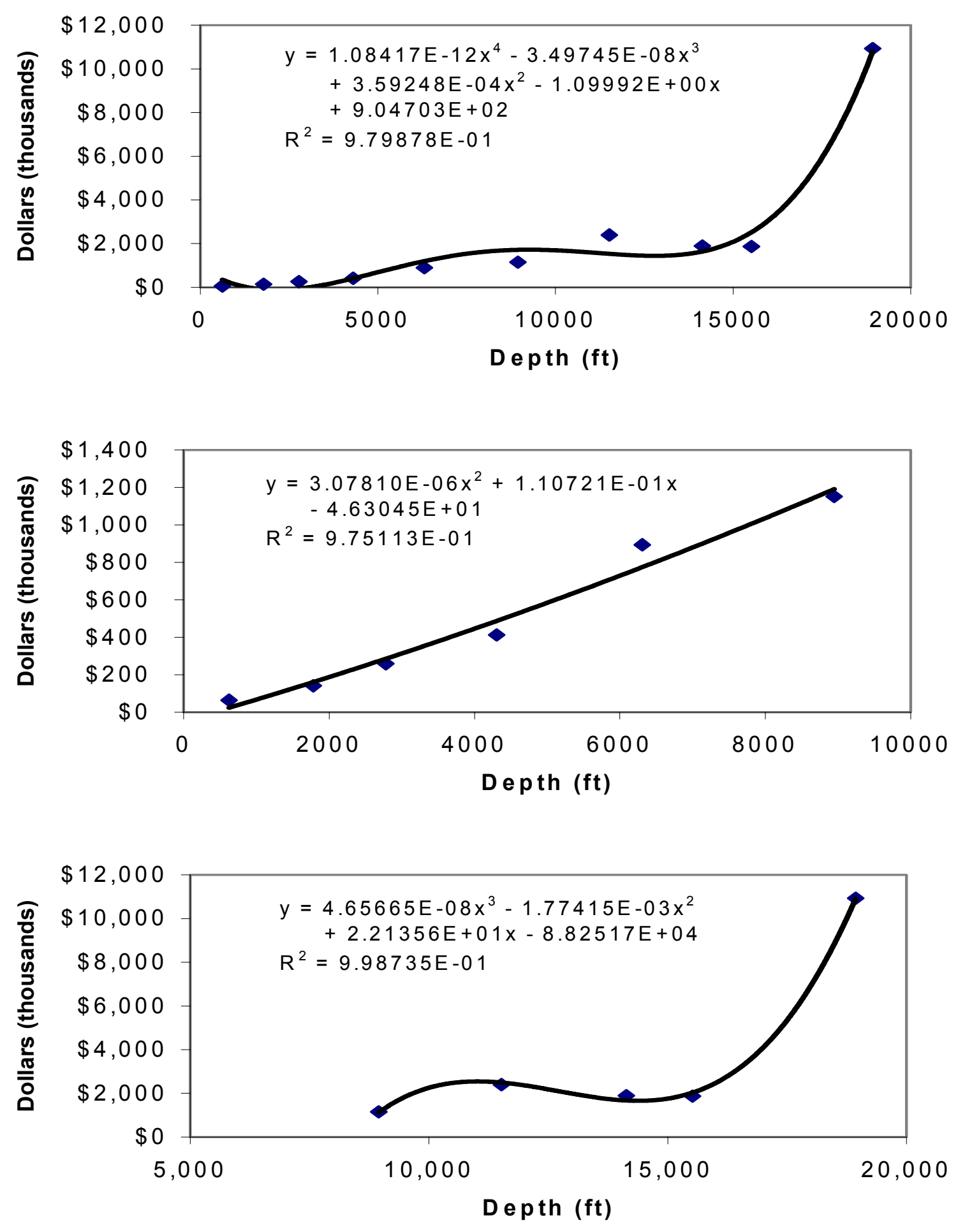
New Mexico
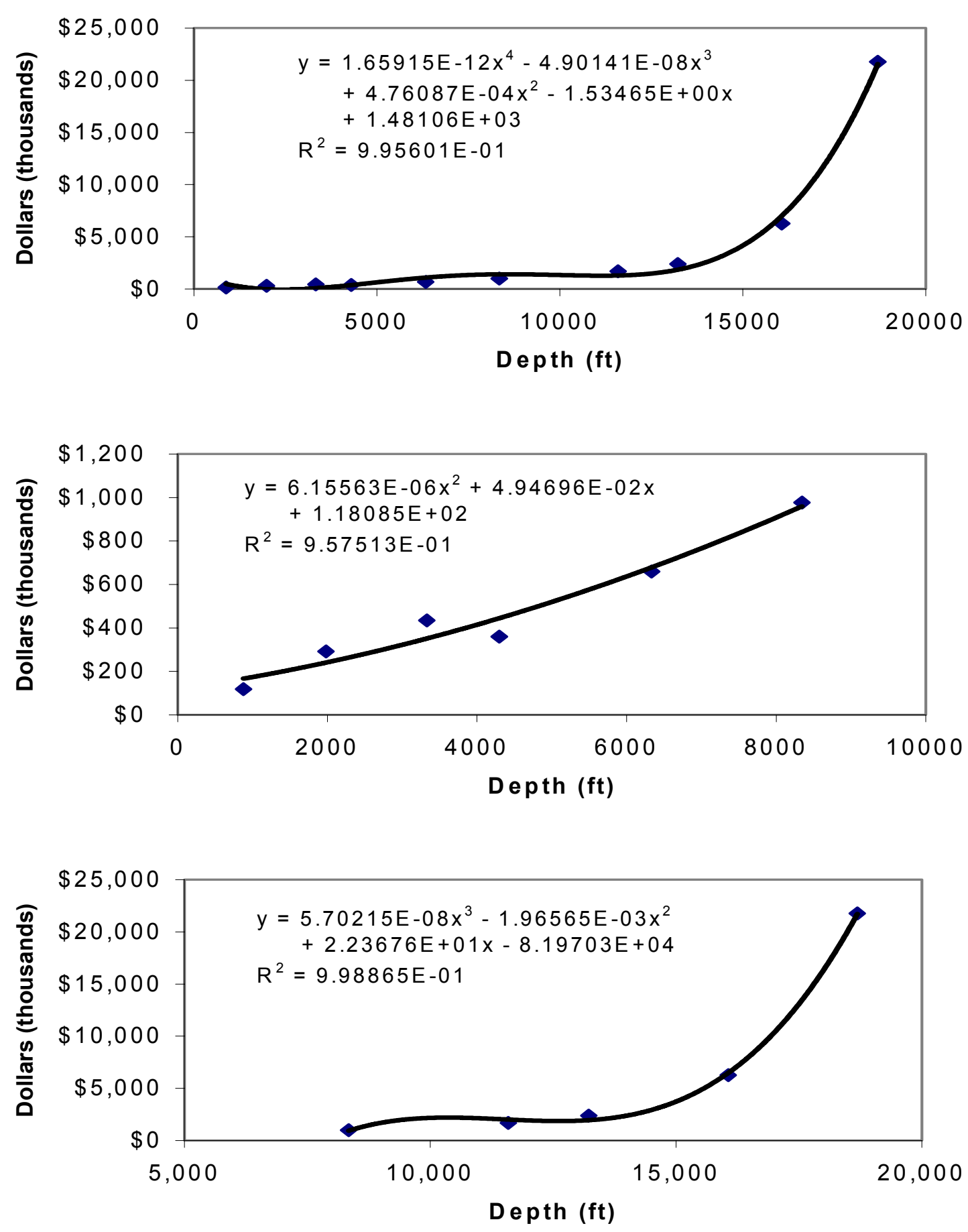


\section{Texas District 8}
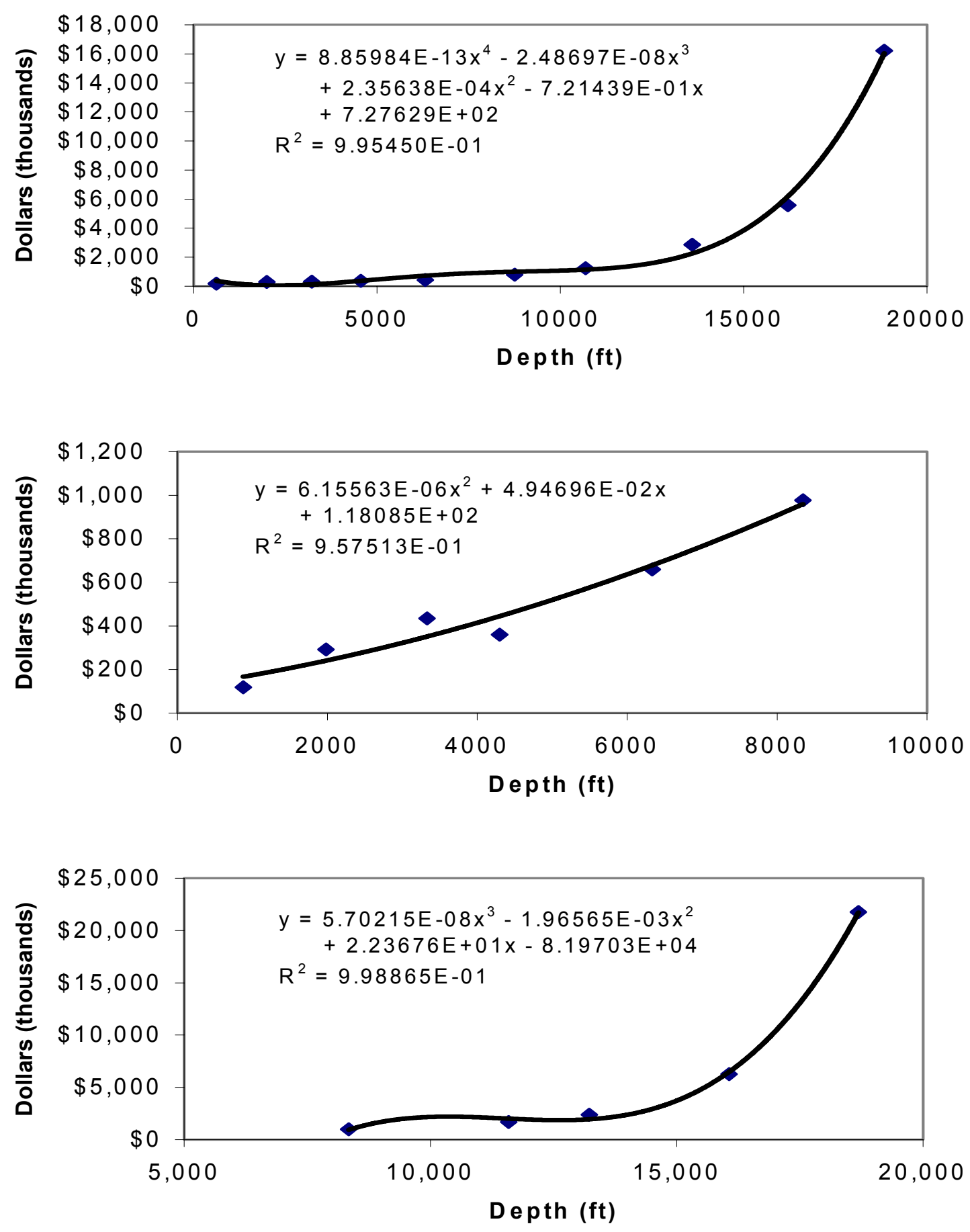


\section{Texas District 8A}
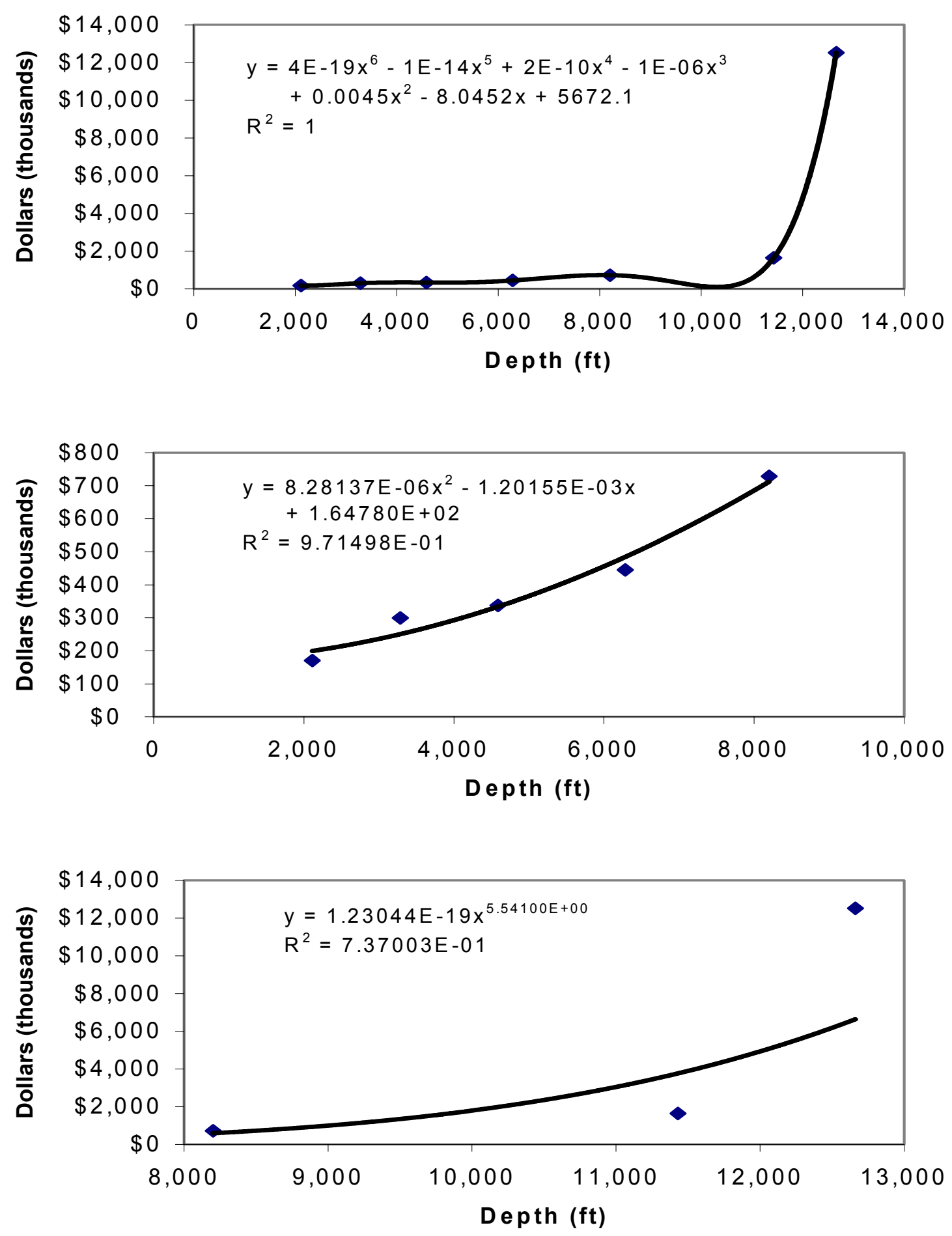


\section{Utah}
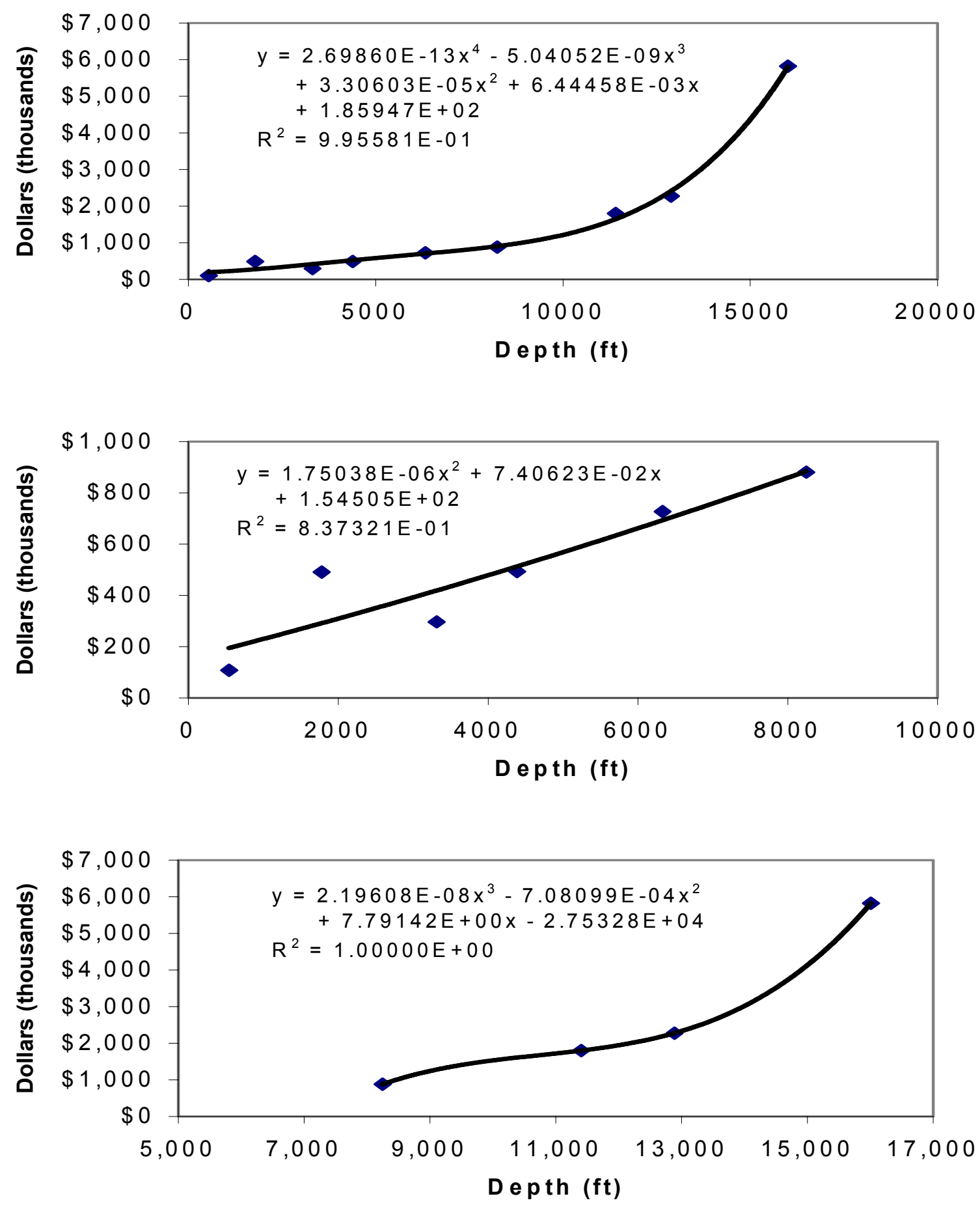


\section{Wyoming}
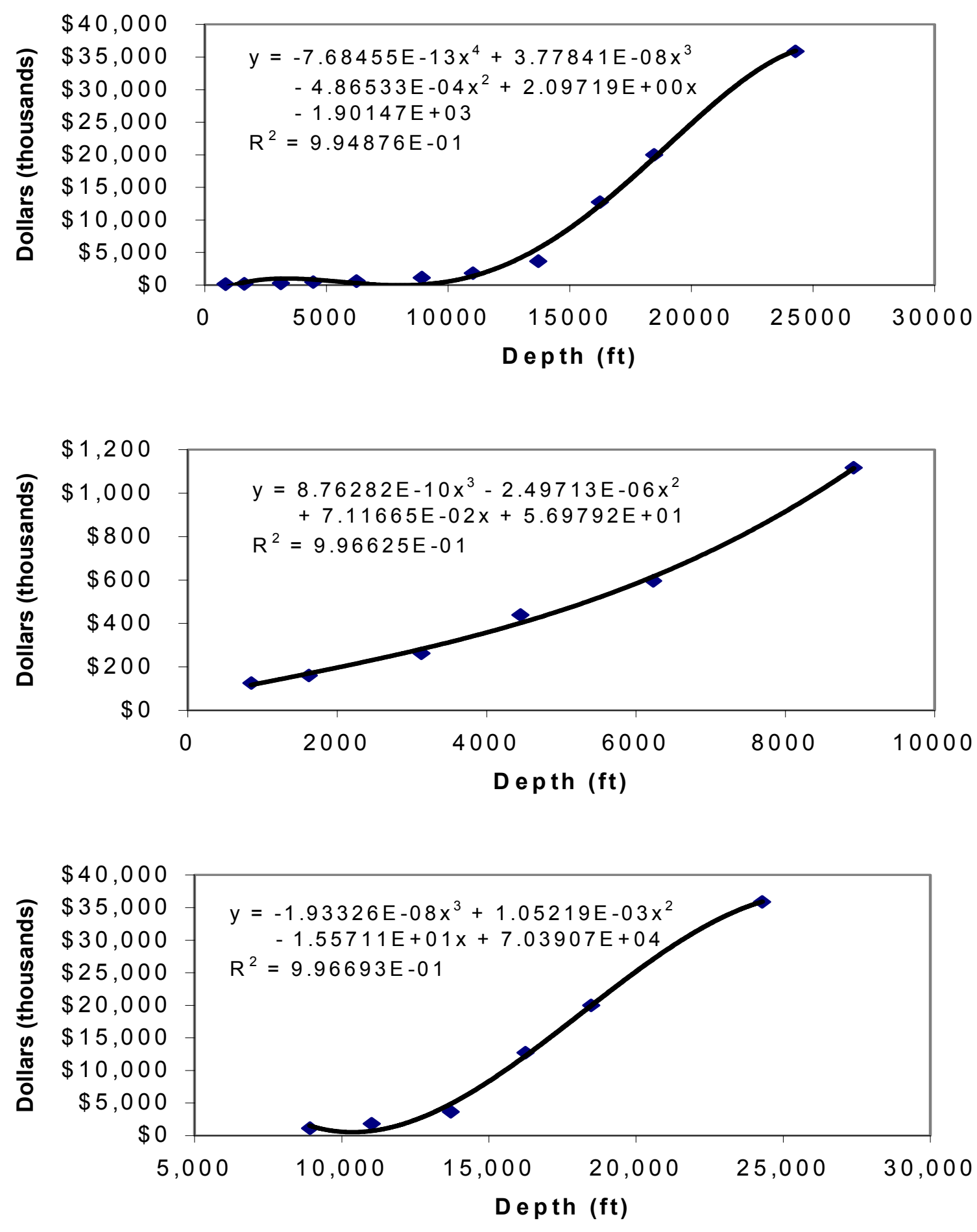


\section{North Louisiana}
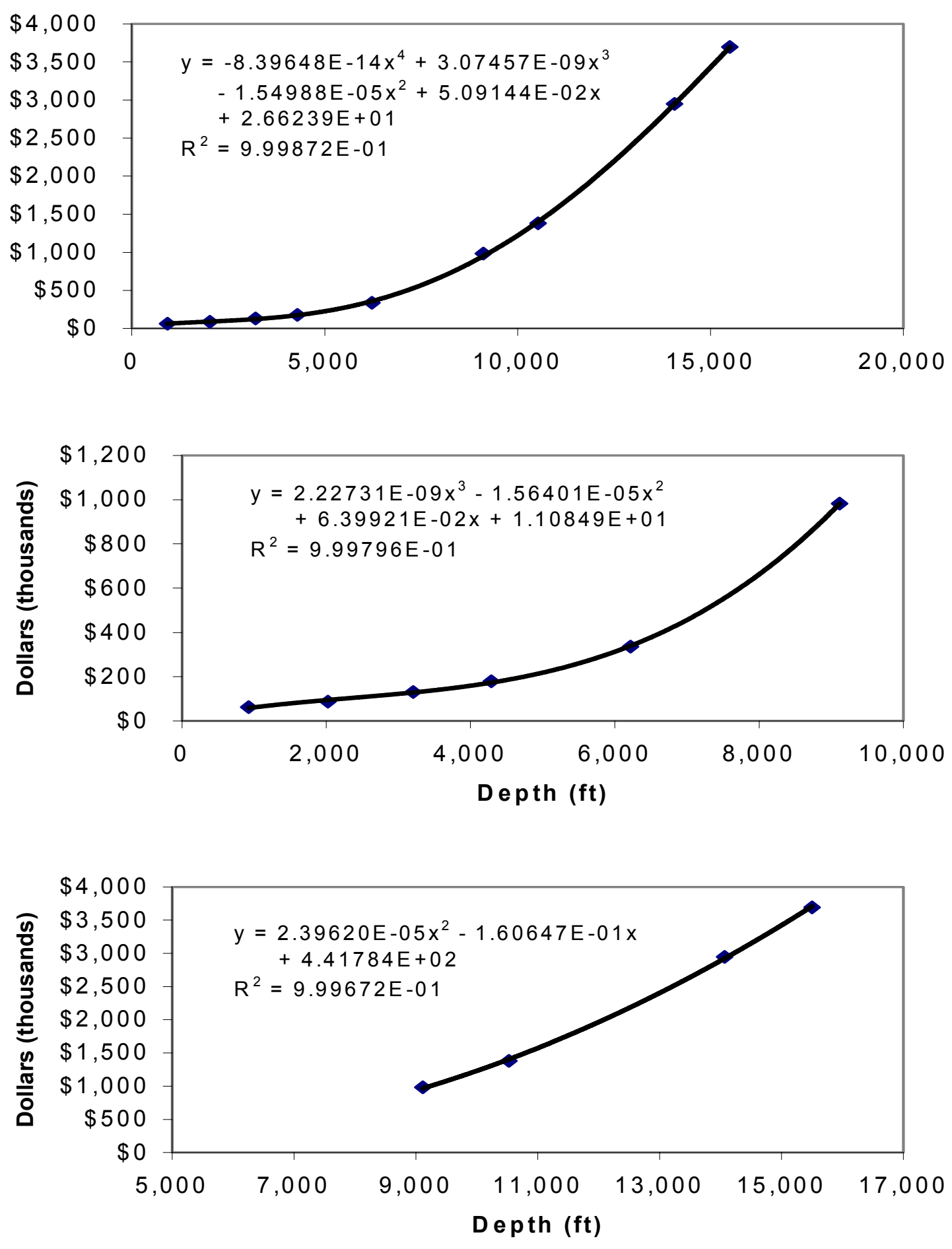


\section{Arkansas}
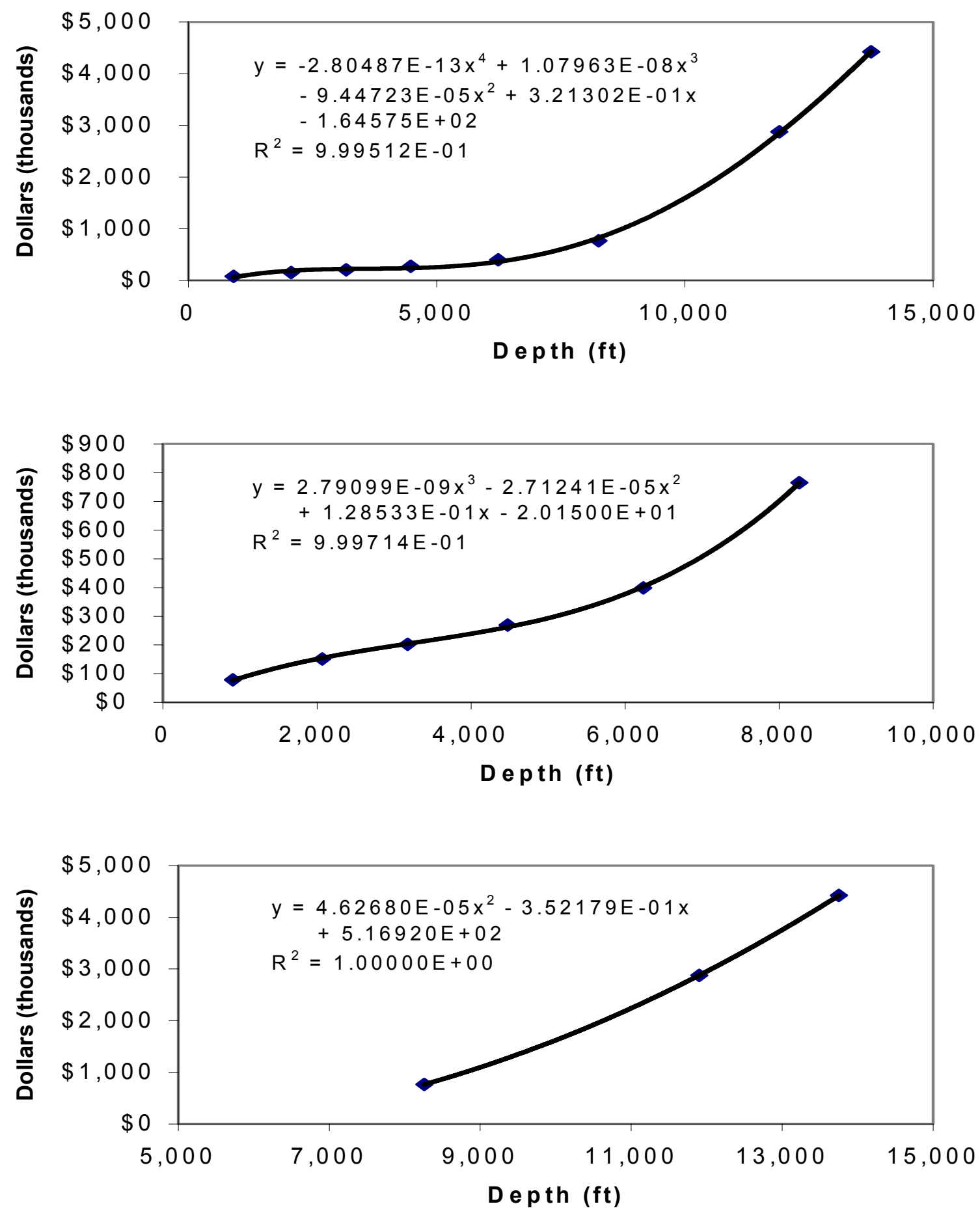


\section{Total Wells Surveyed Southeast United States}
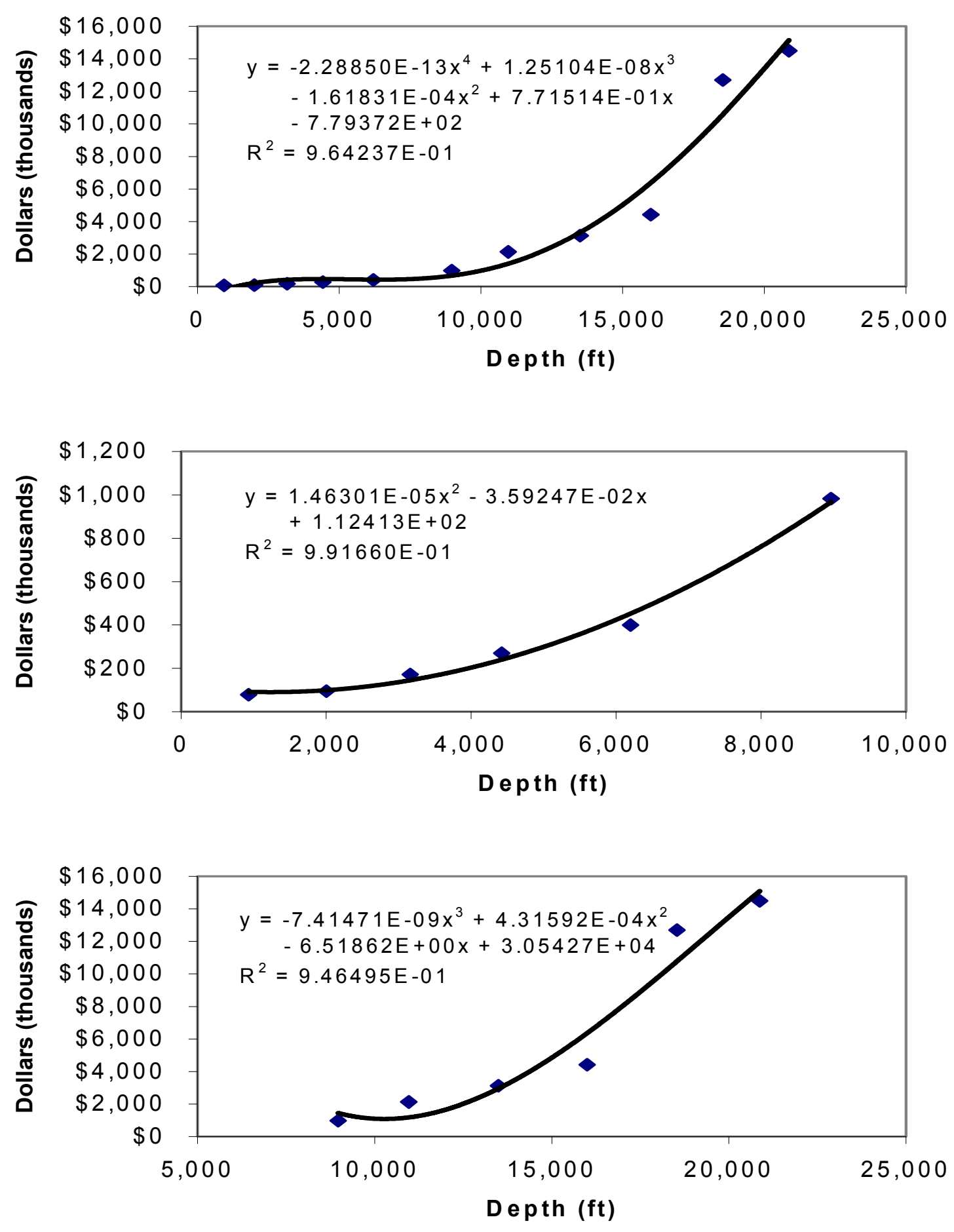
Total Wells Surveyed Western and Southeast United States
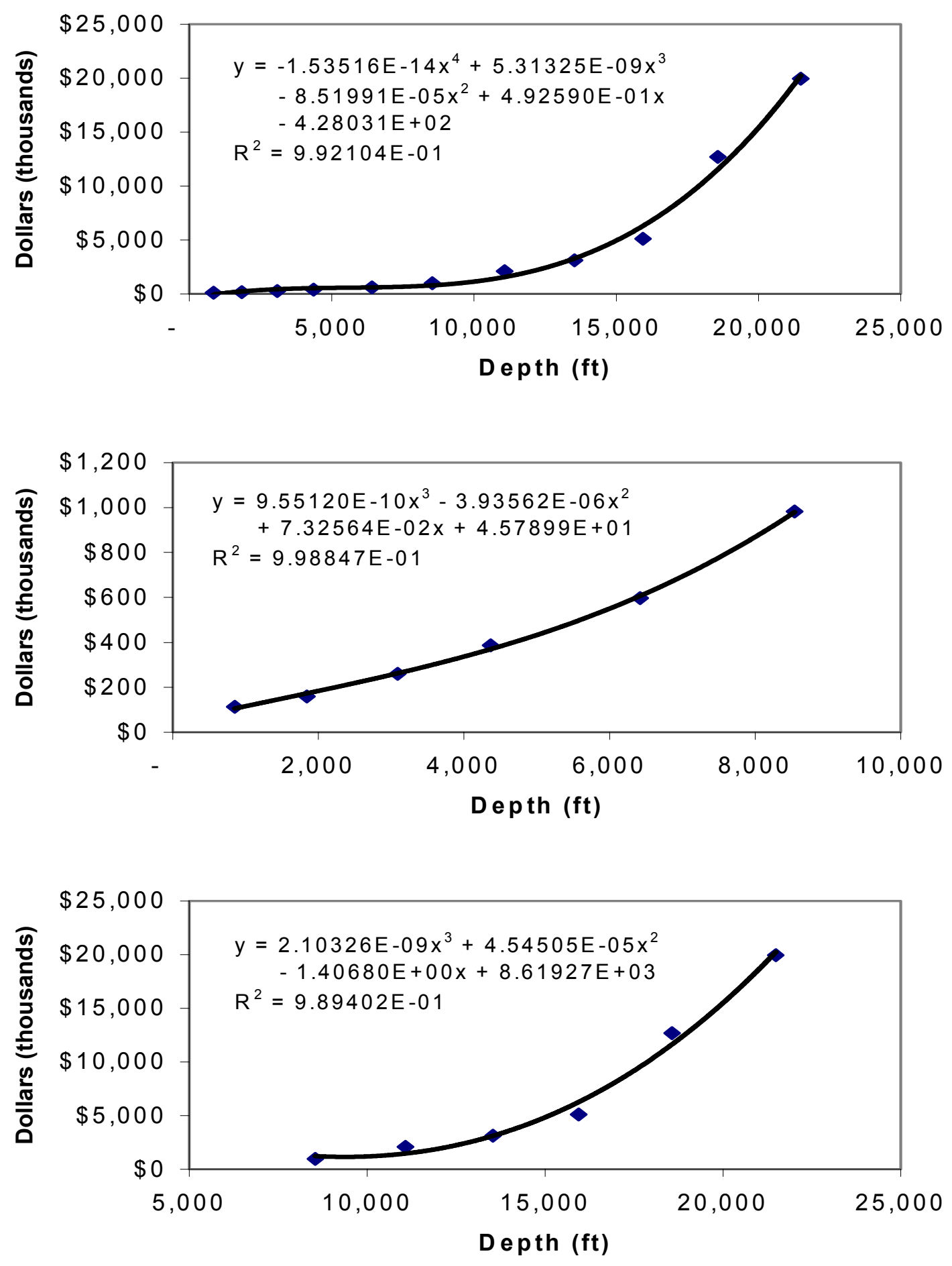


\section{Kansas}

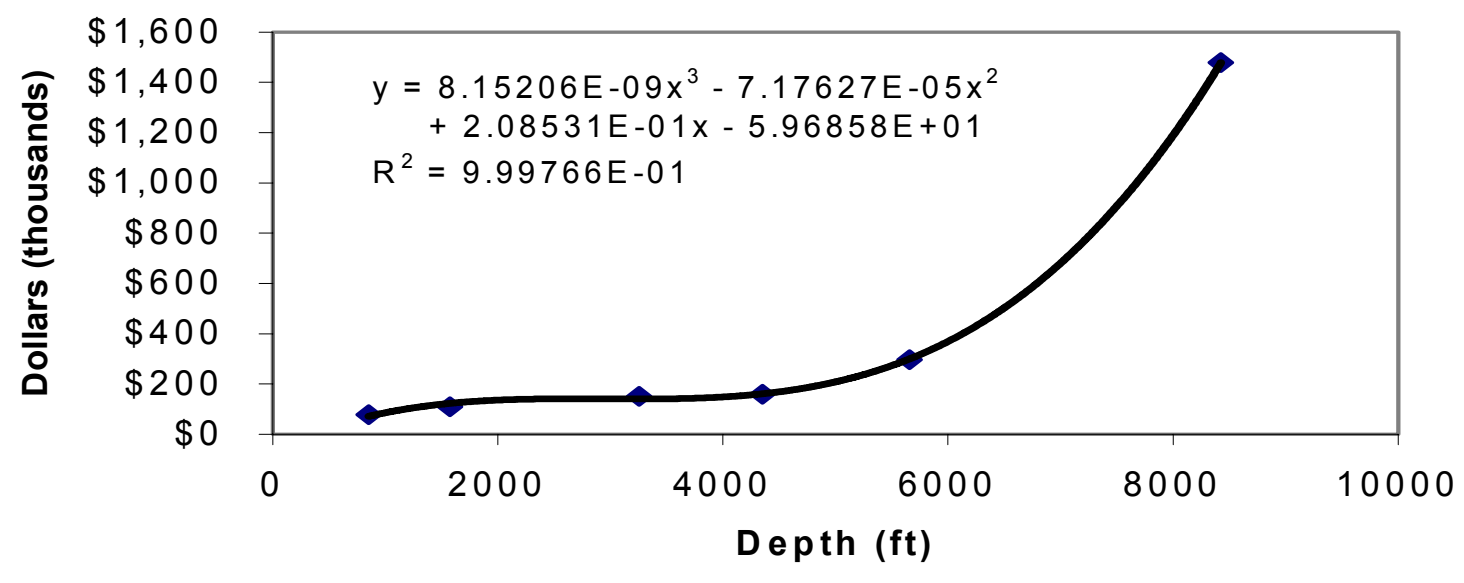

North Dakota

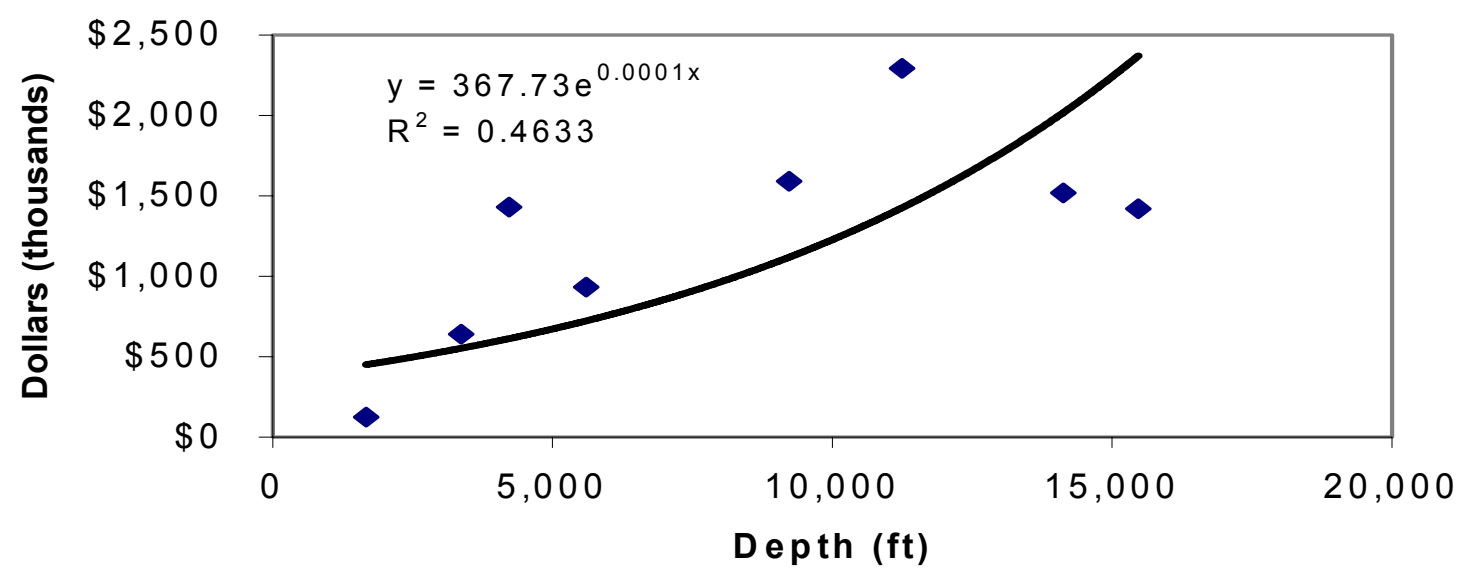




\section{Oklahoma}
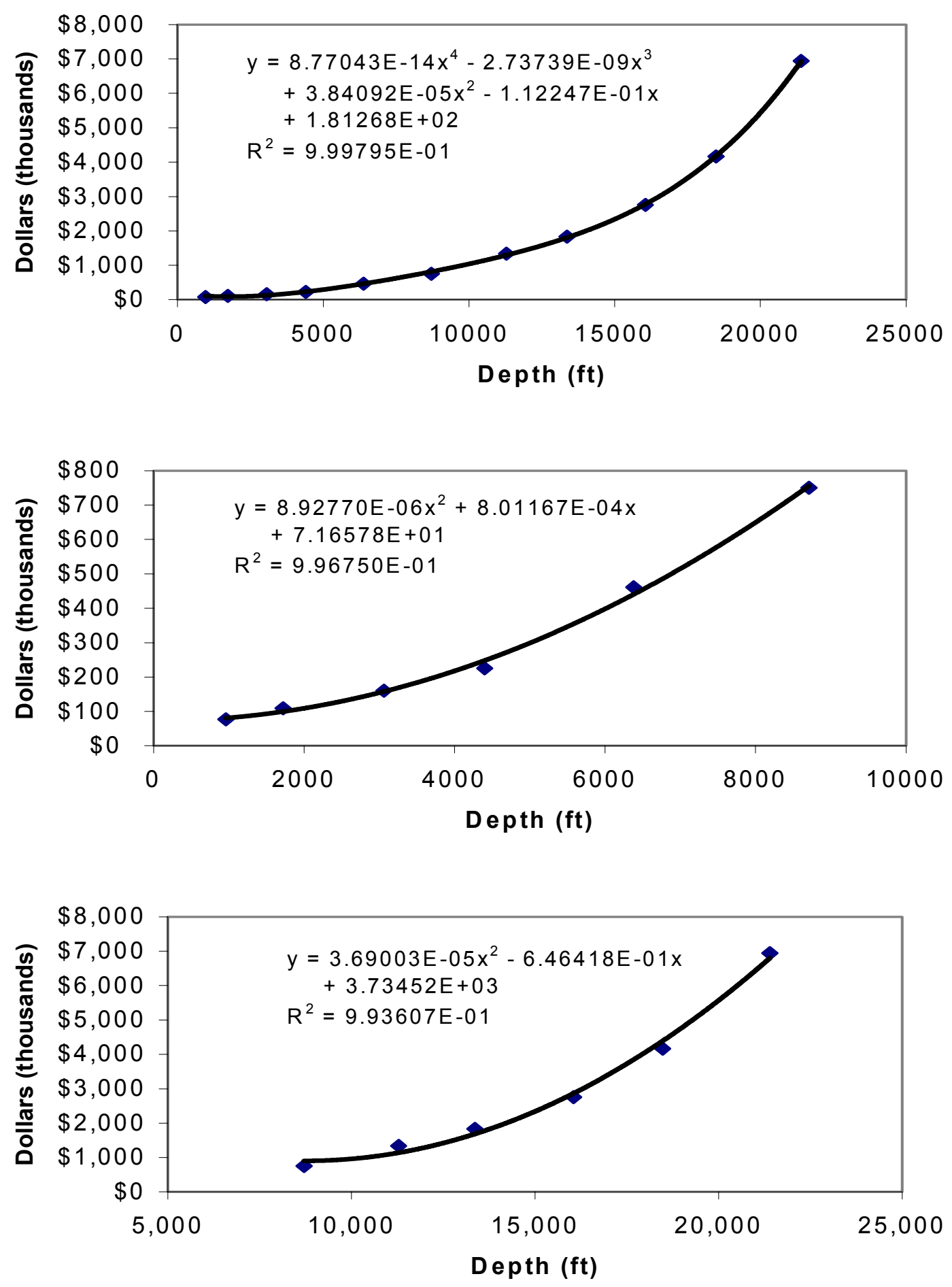


\section{Exponential Curve Fitting Plots}

\section{Exponential Curve Fit For All Wells Surveyed}
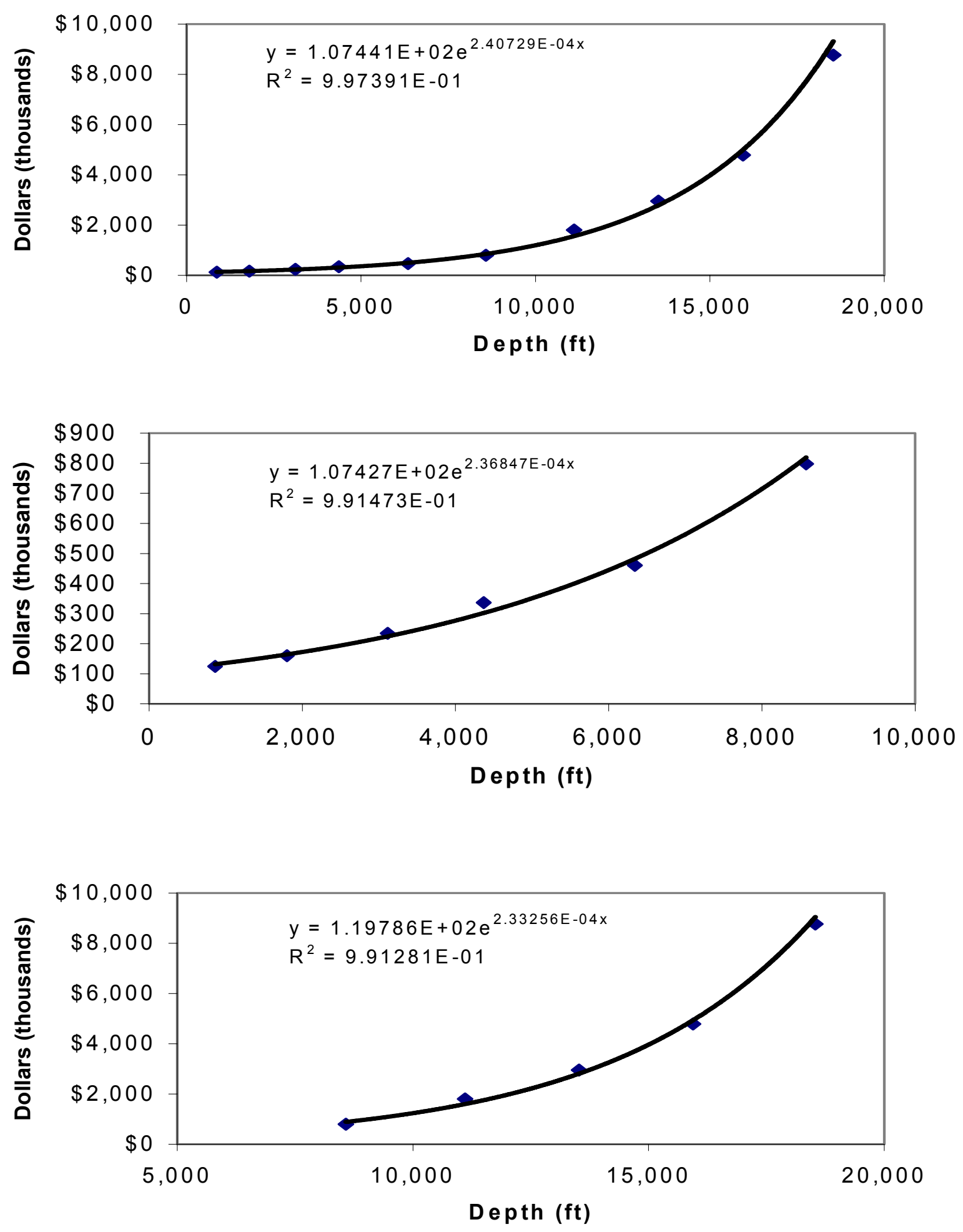
Western States

\section{California onshore}
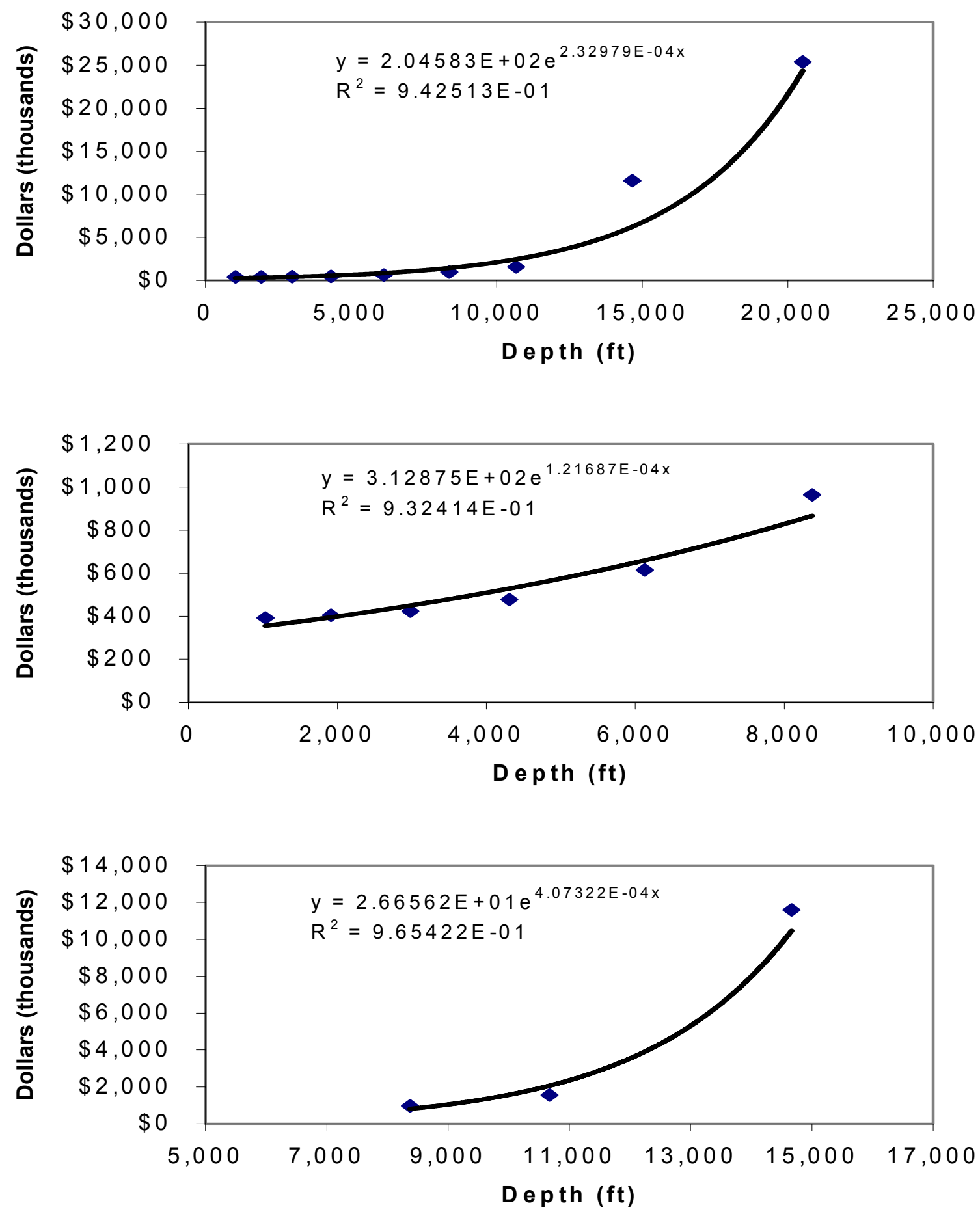


\section{Colorado}
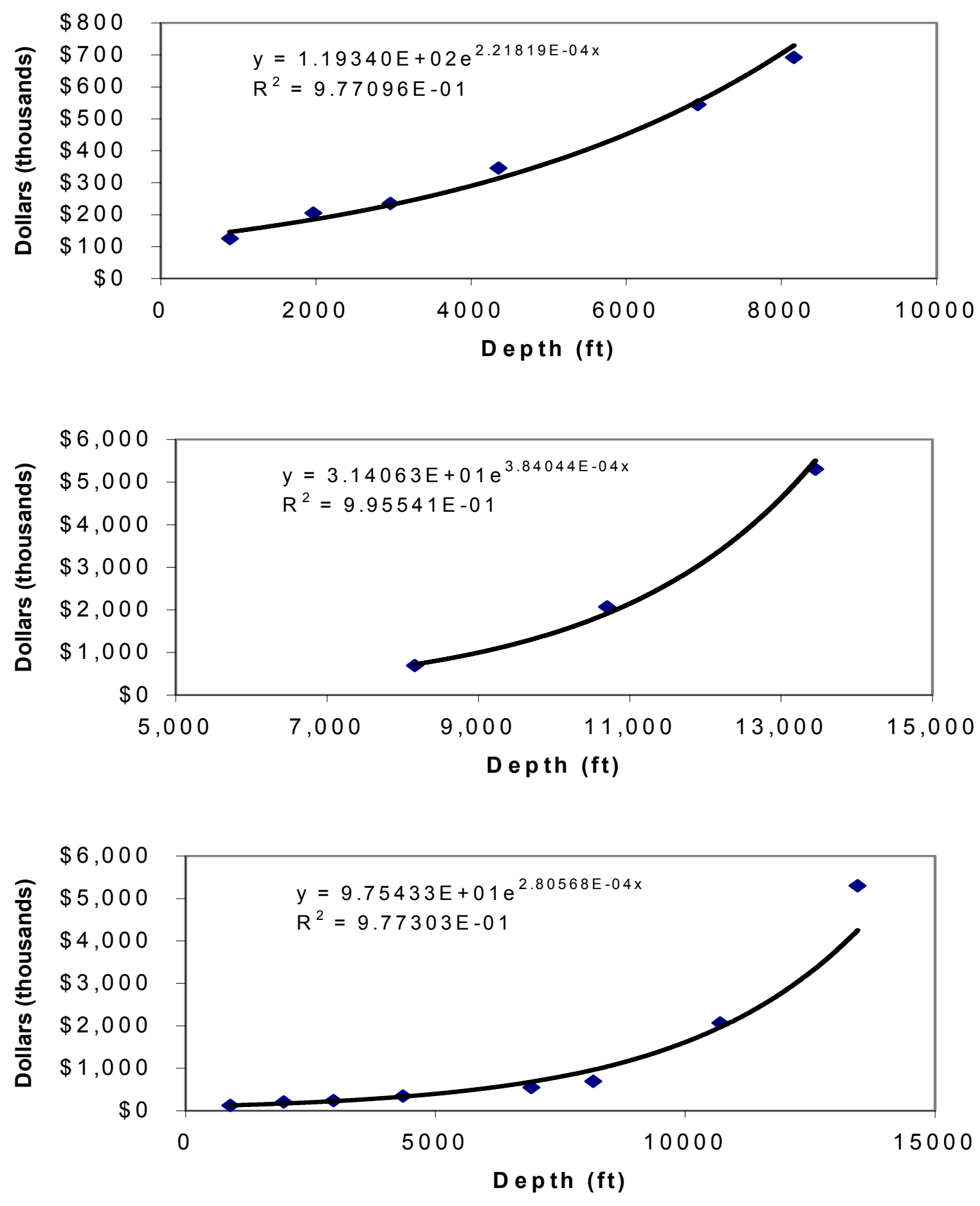


\section{Montana}
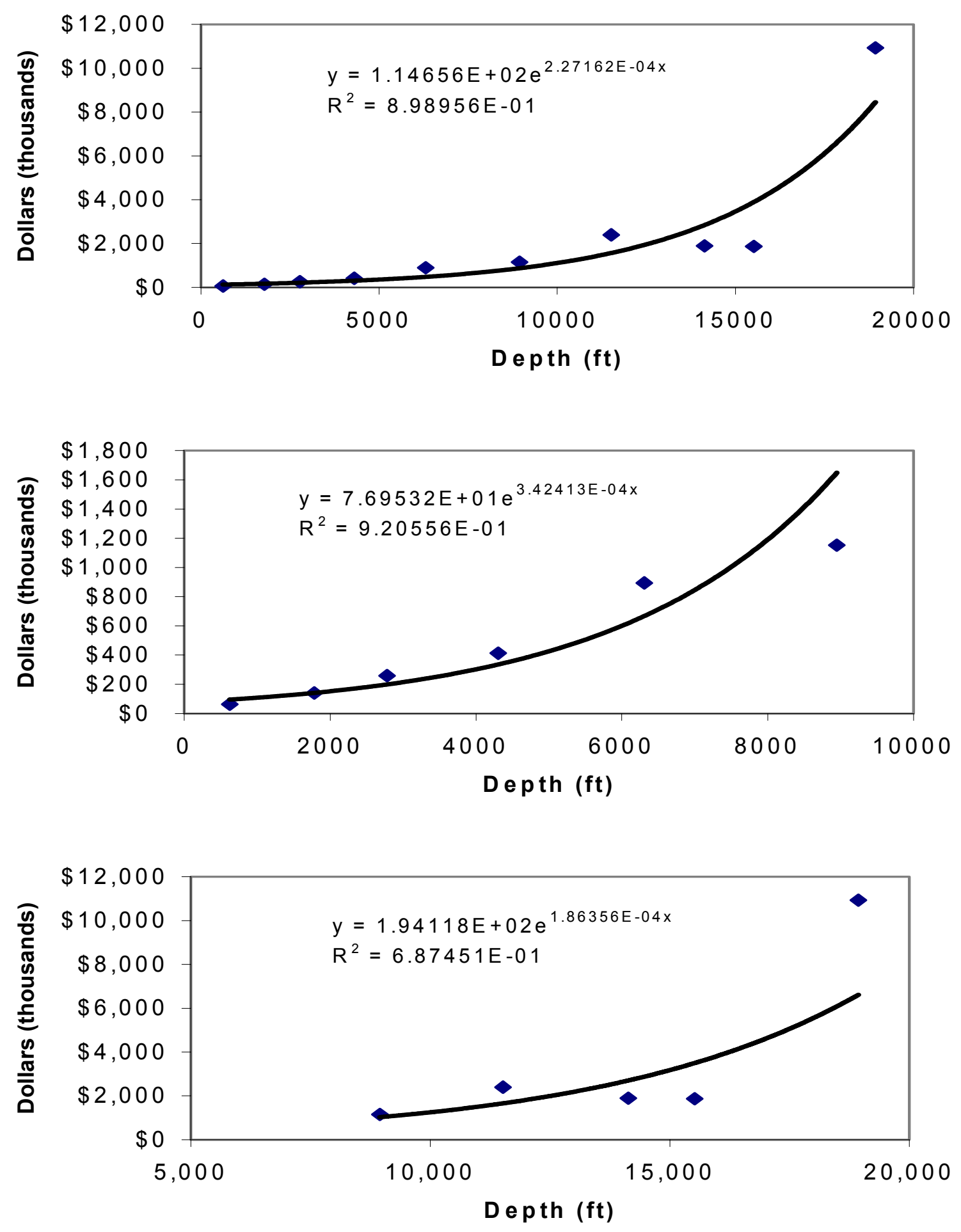
New Mexico
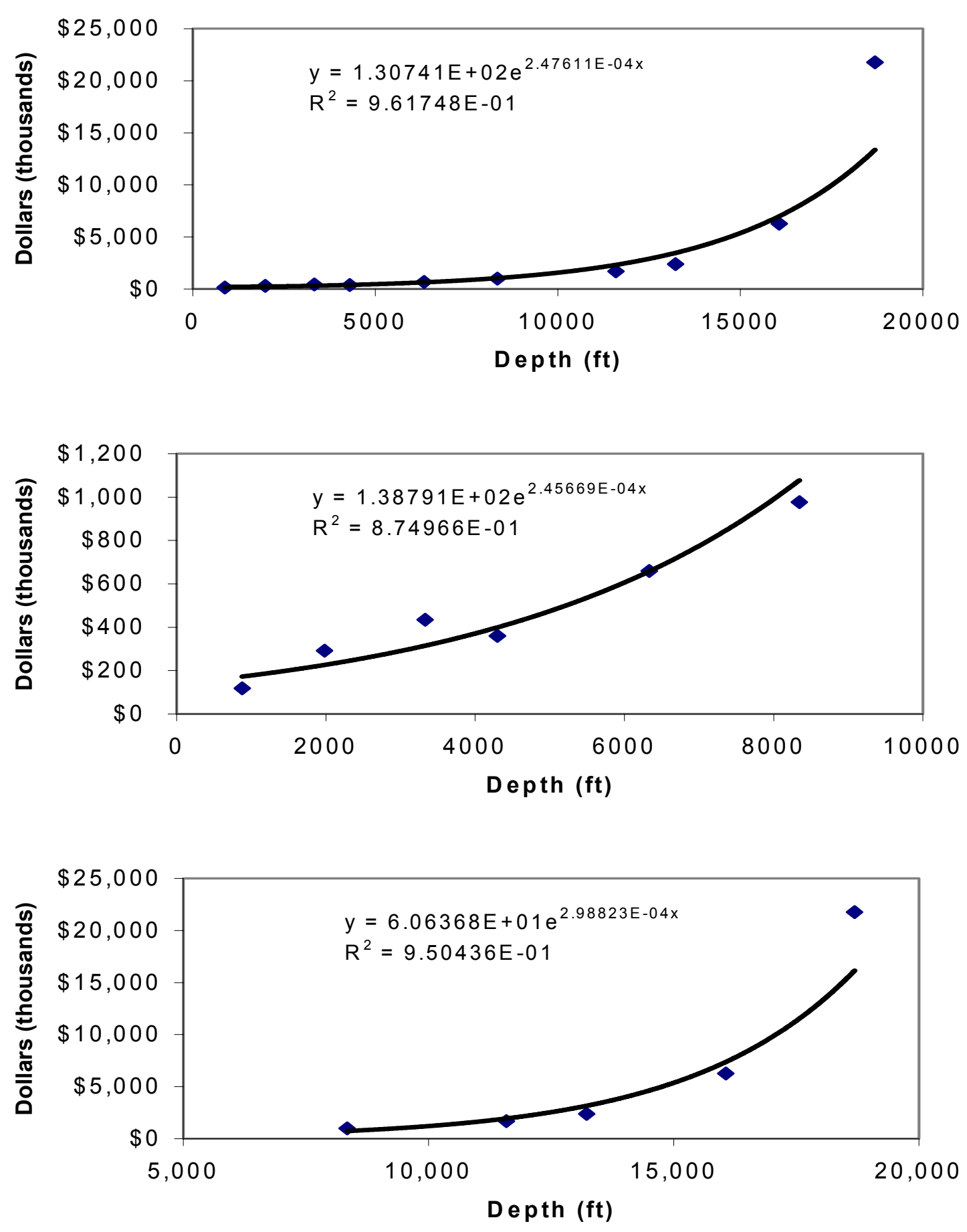


\section{Texas District 8}
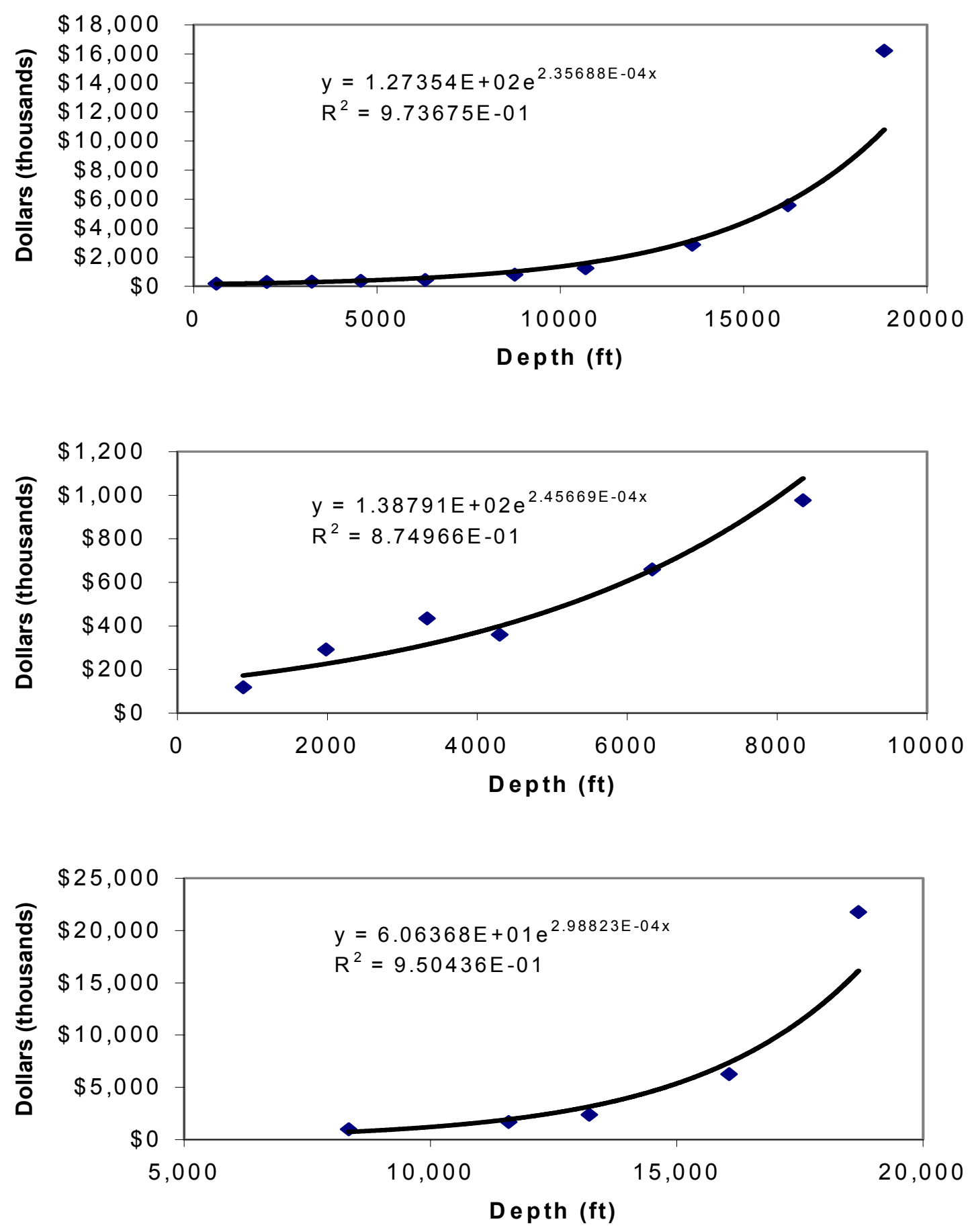


\section{Texas District 8A}
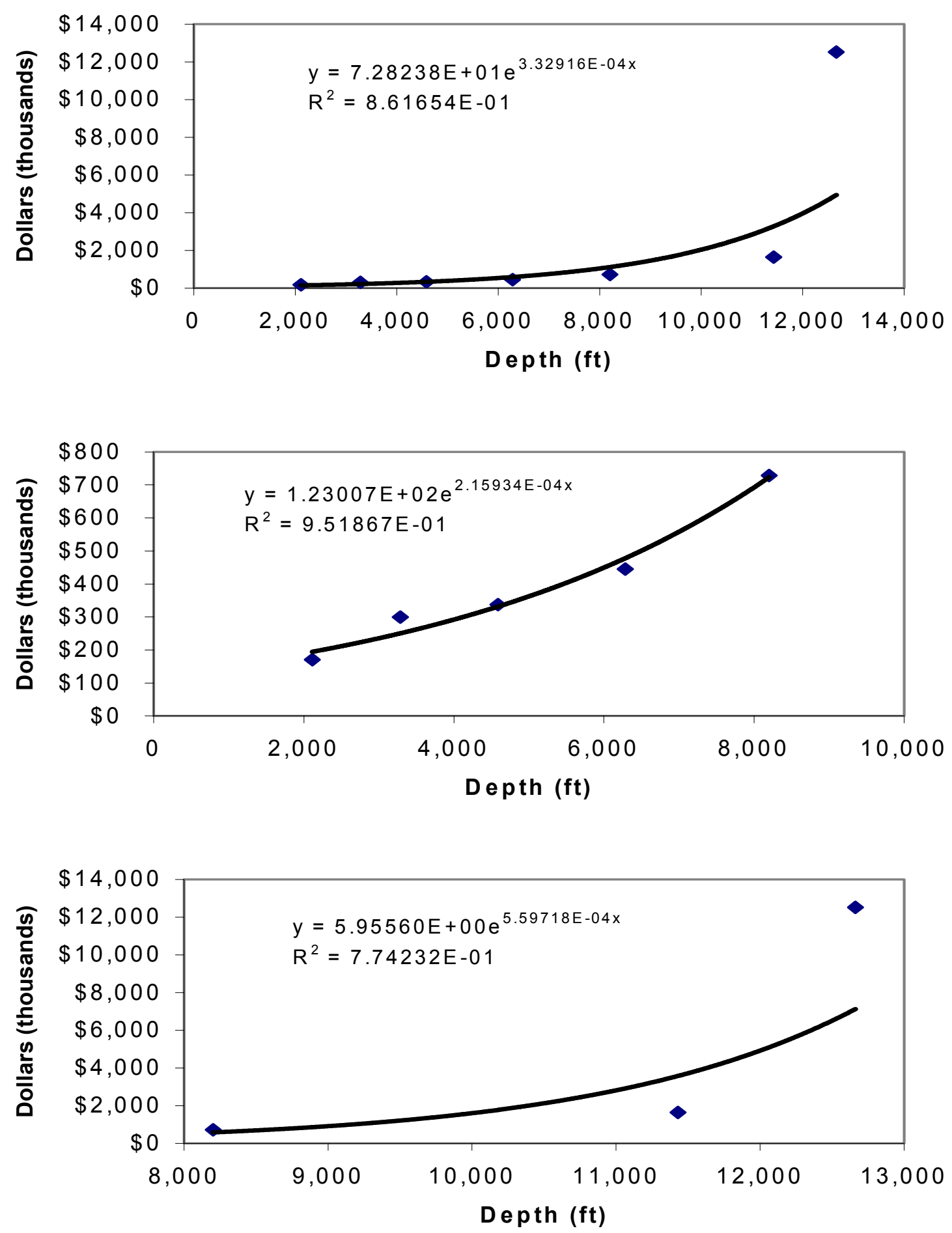


\section{Utah}
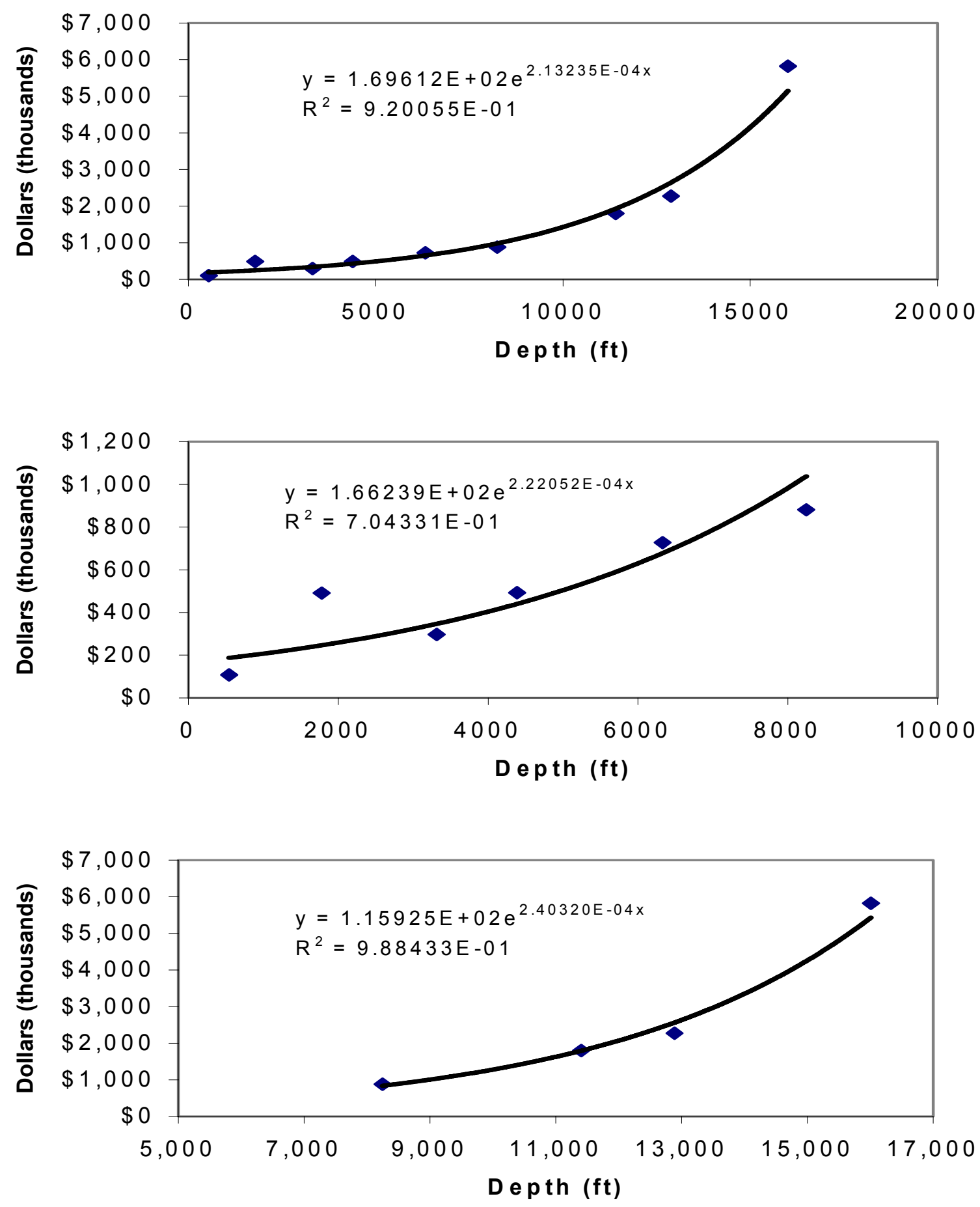


\section{Wyoming}
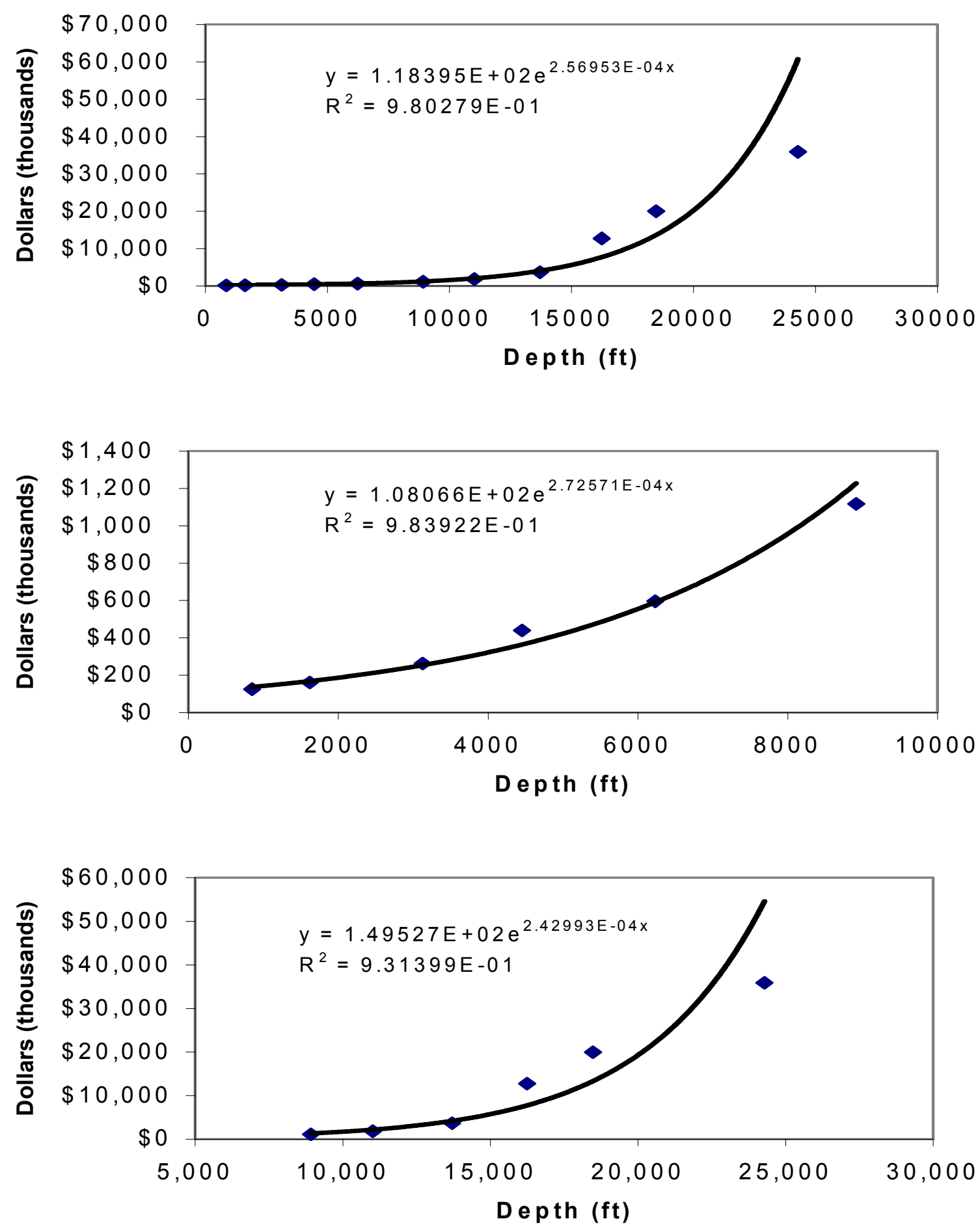


\section{Western U.S. States total wells surveyed}
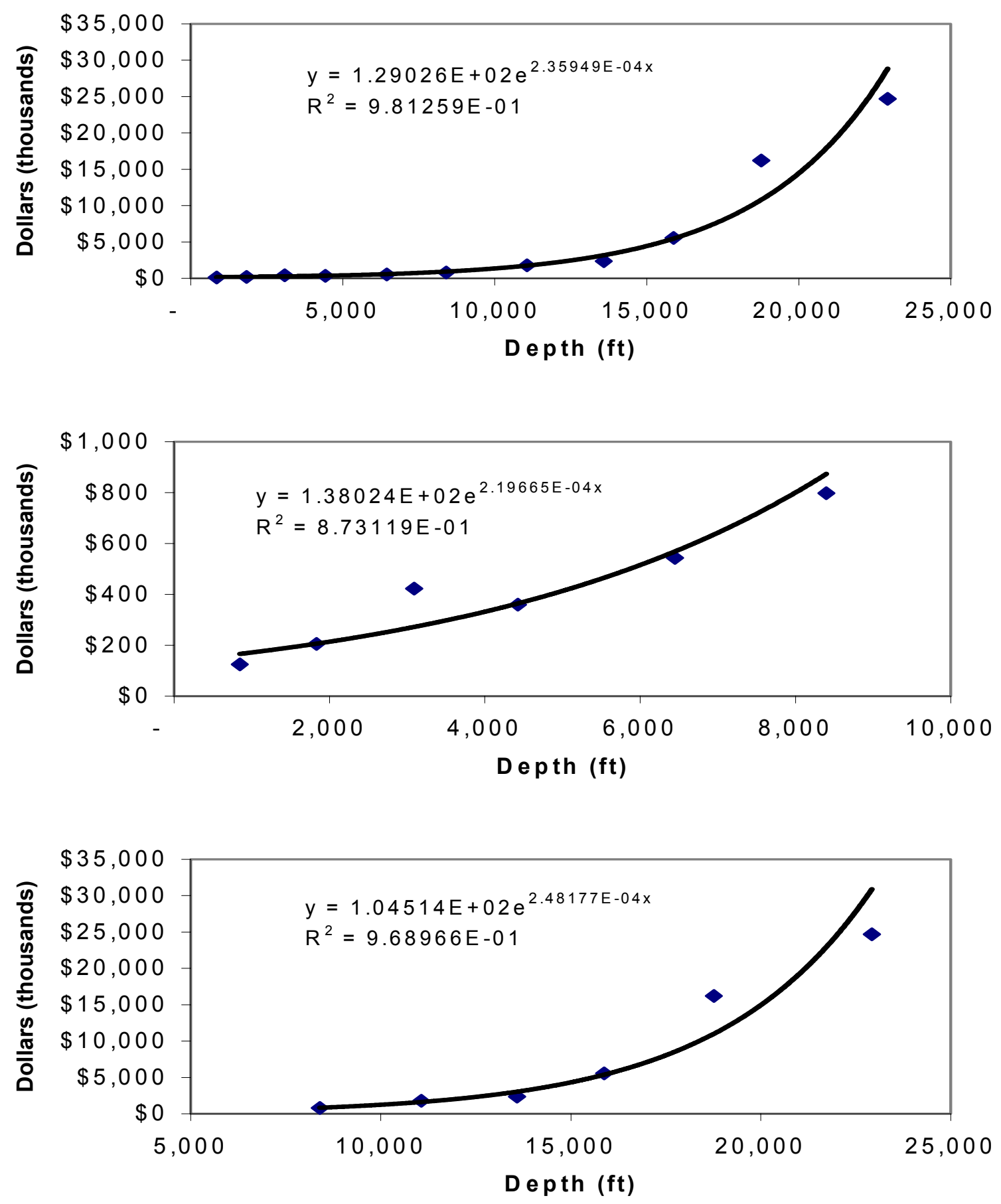


\section{Southeast United States}

\section{Texas Districts 2, 3 and 4}
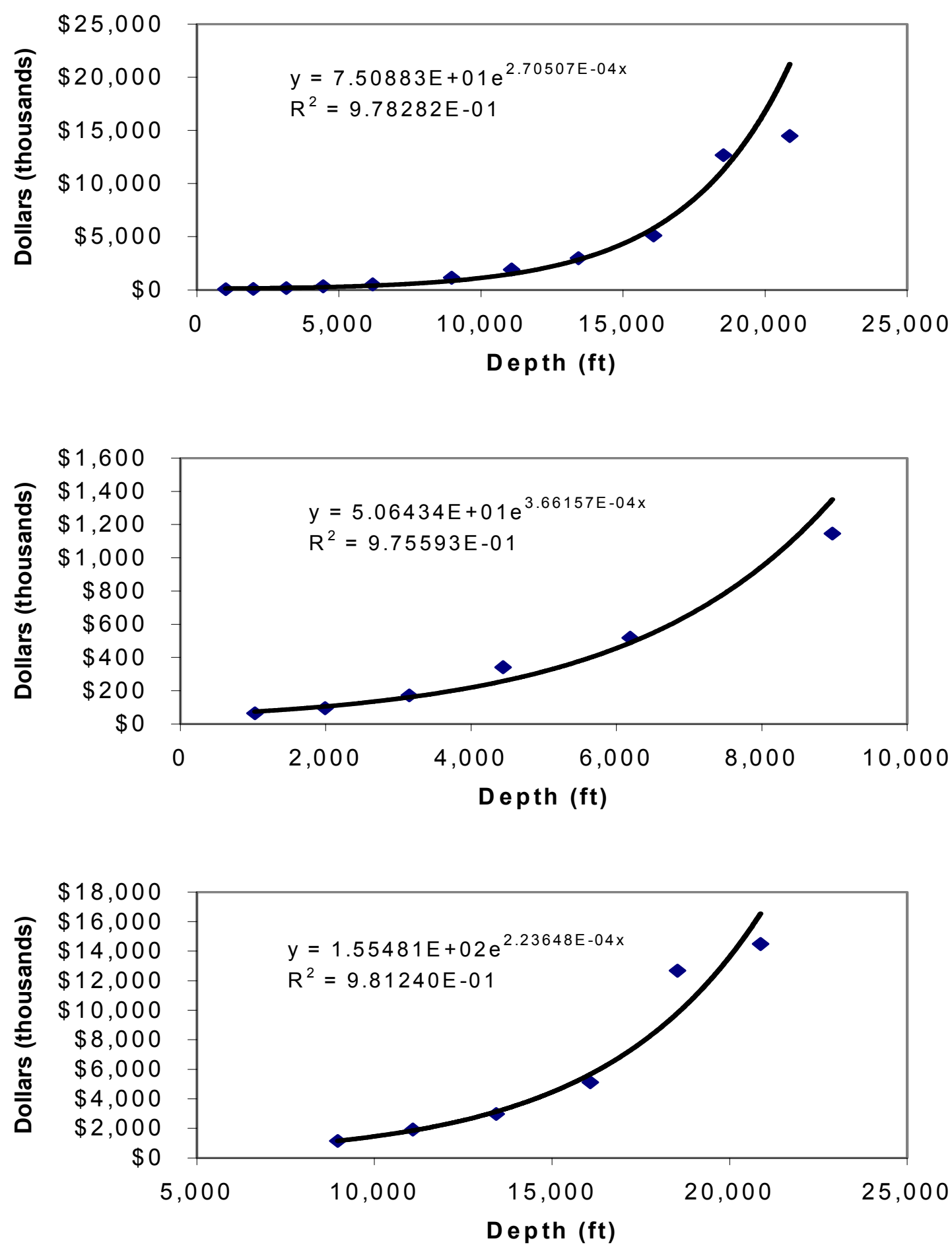


\section{North Louisiana}
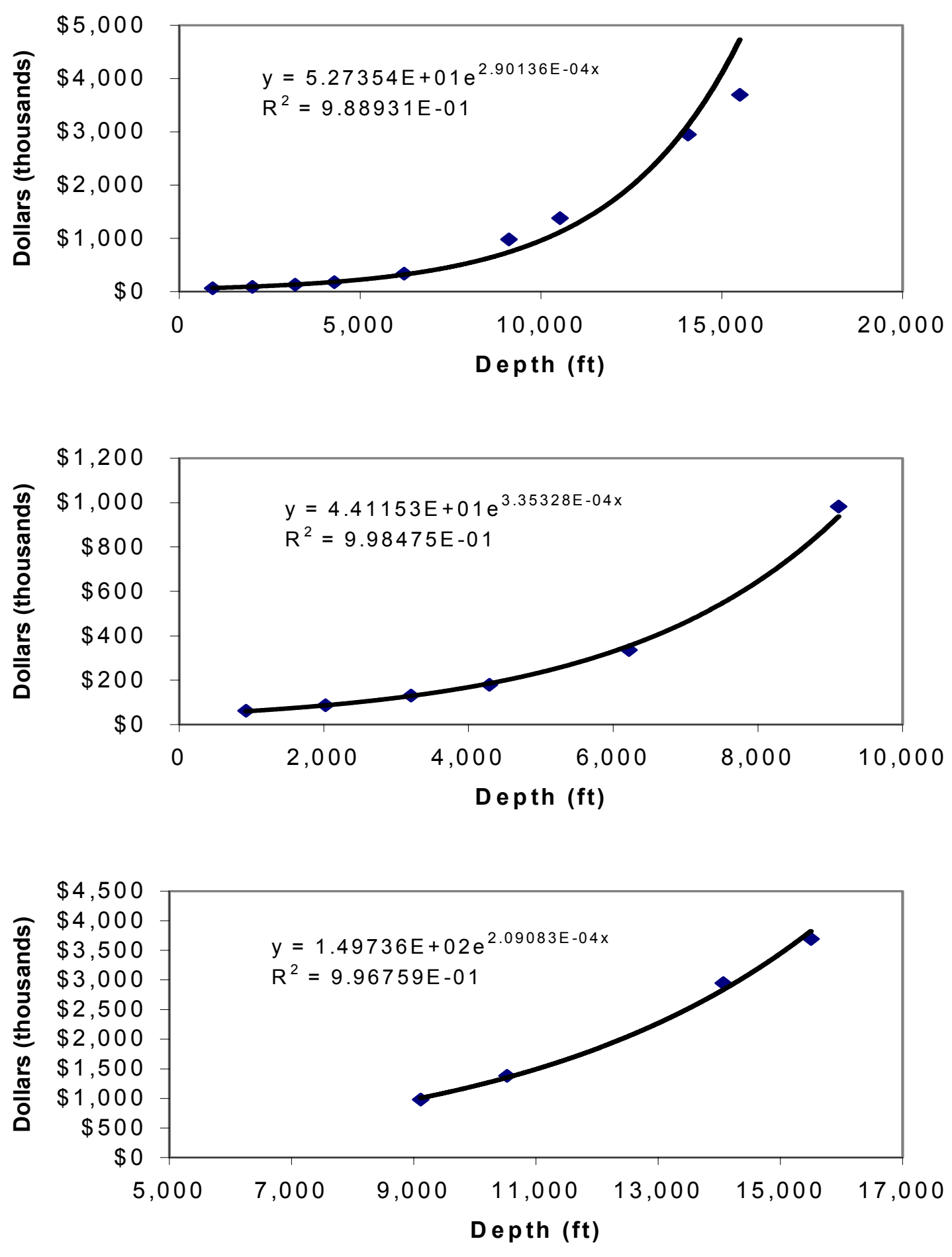


\section{Arkansas}
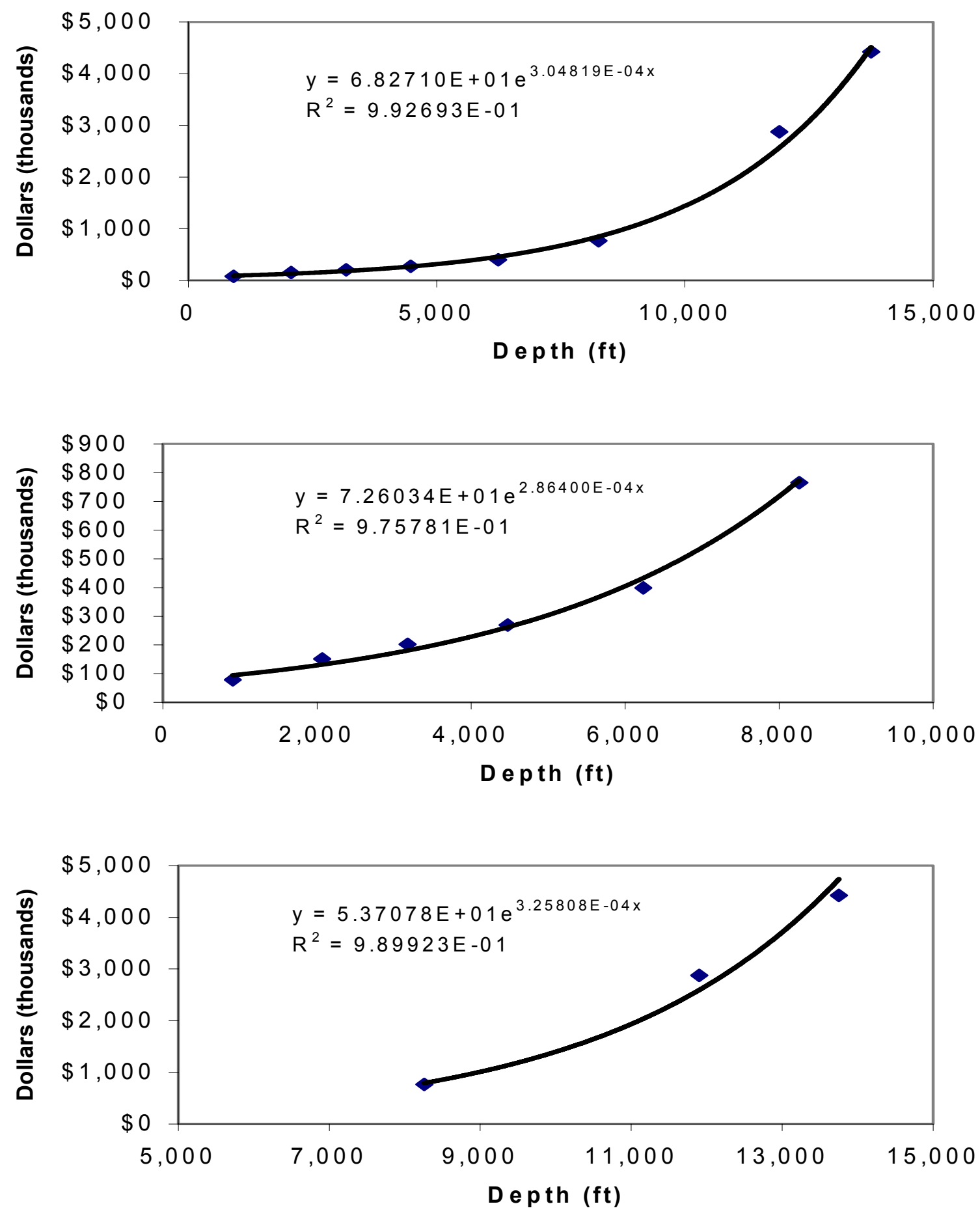


\section{Total Wells Surveyed Southeast United States}
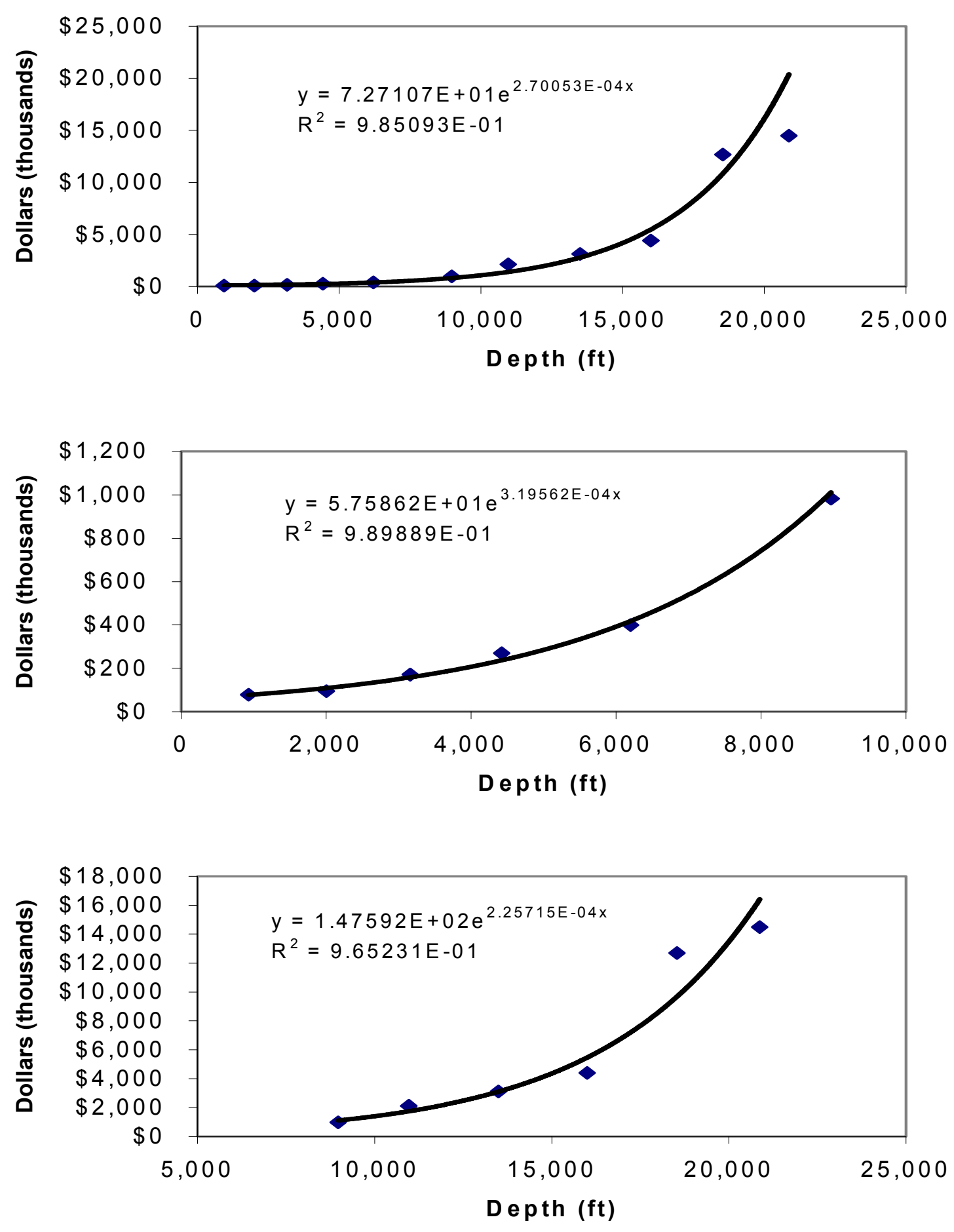


\section{Total Wells Surveyed Western and Southeast United States}
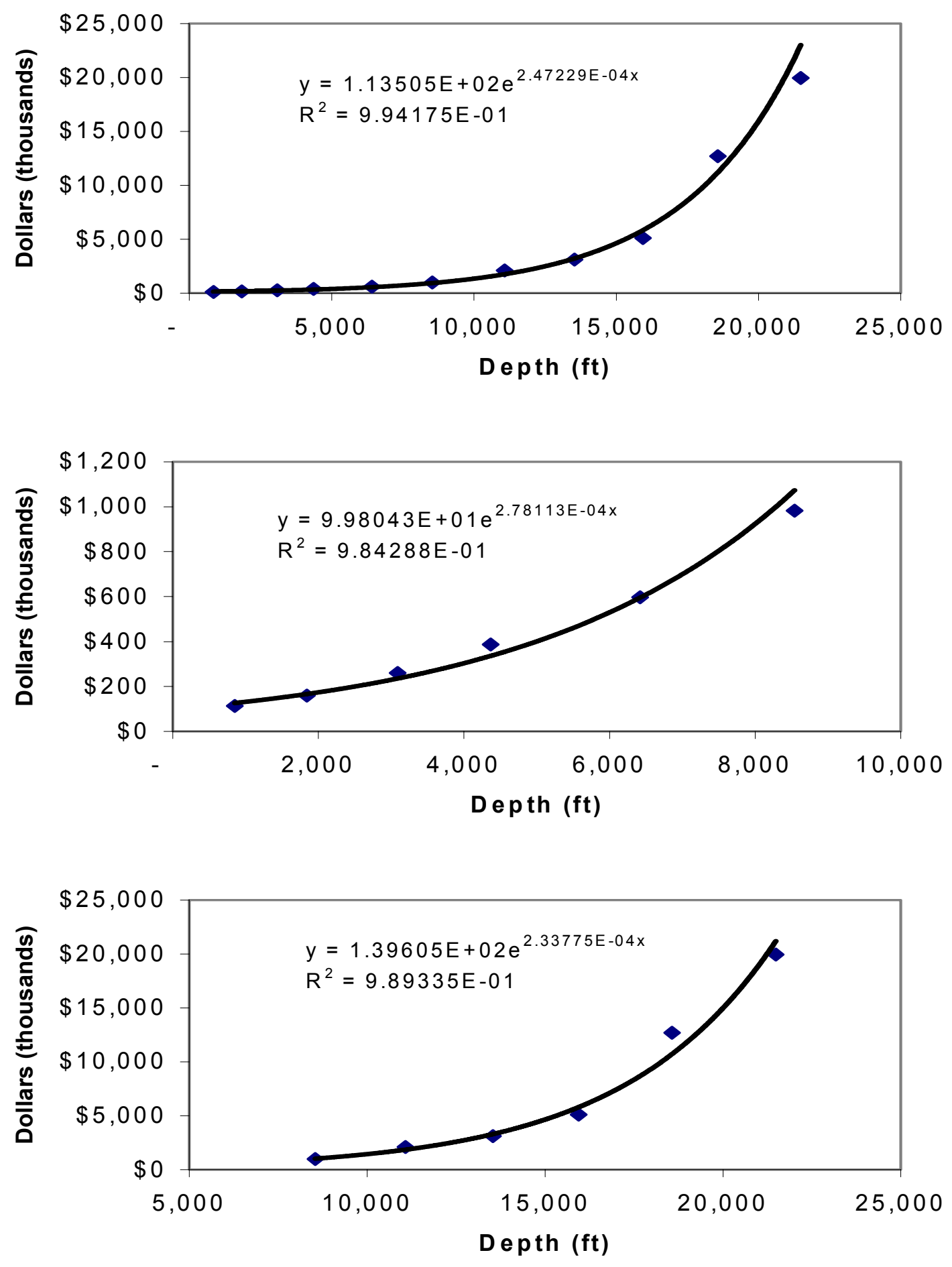


\section{Kansas}

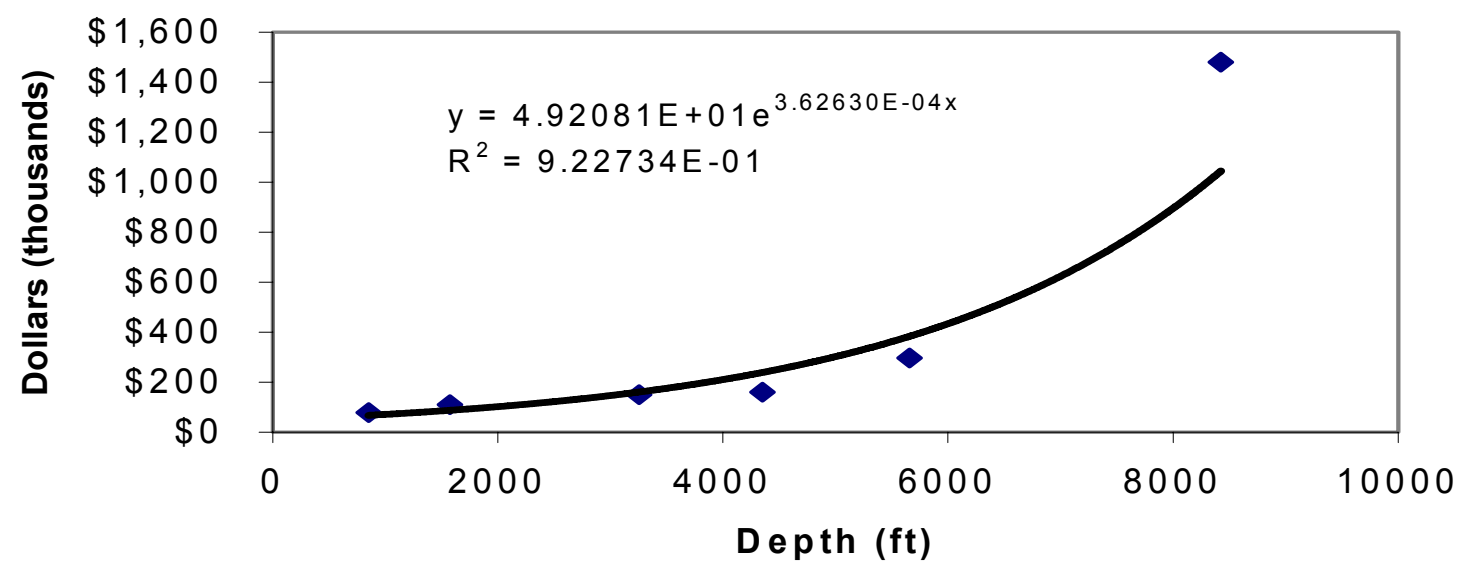

North Dakota

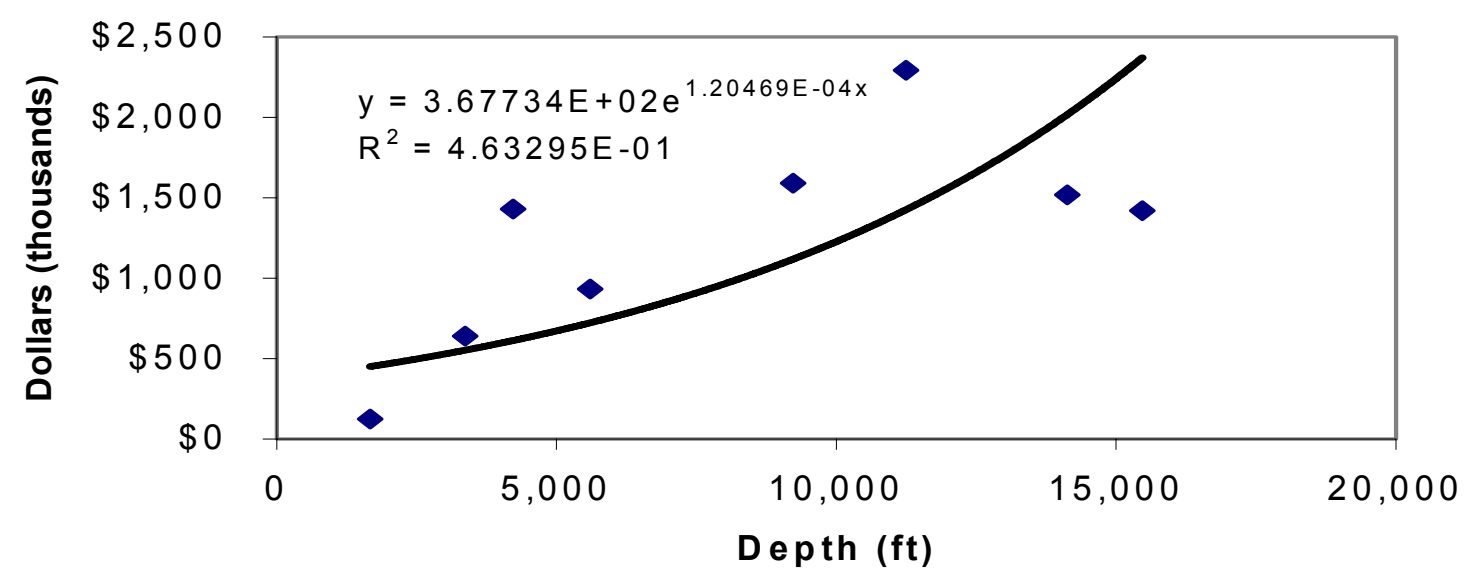




\section{Oklahoma}
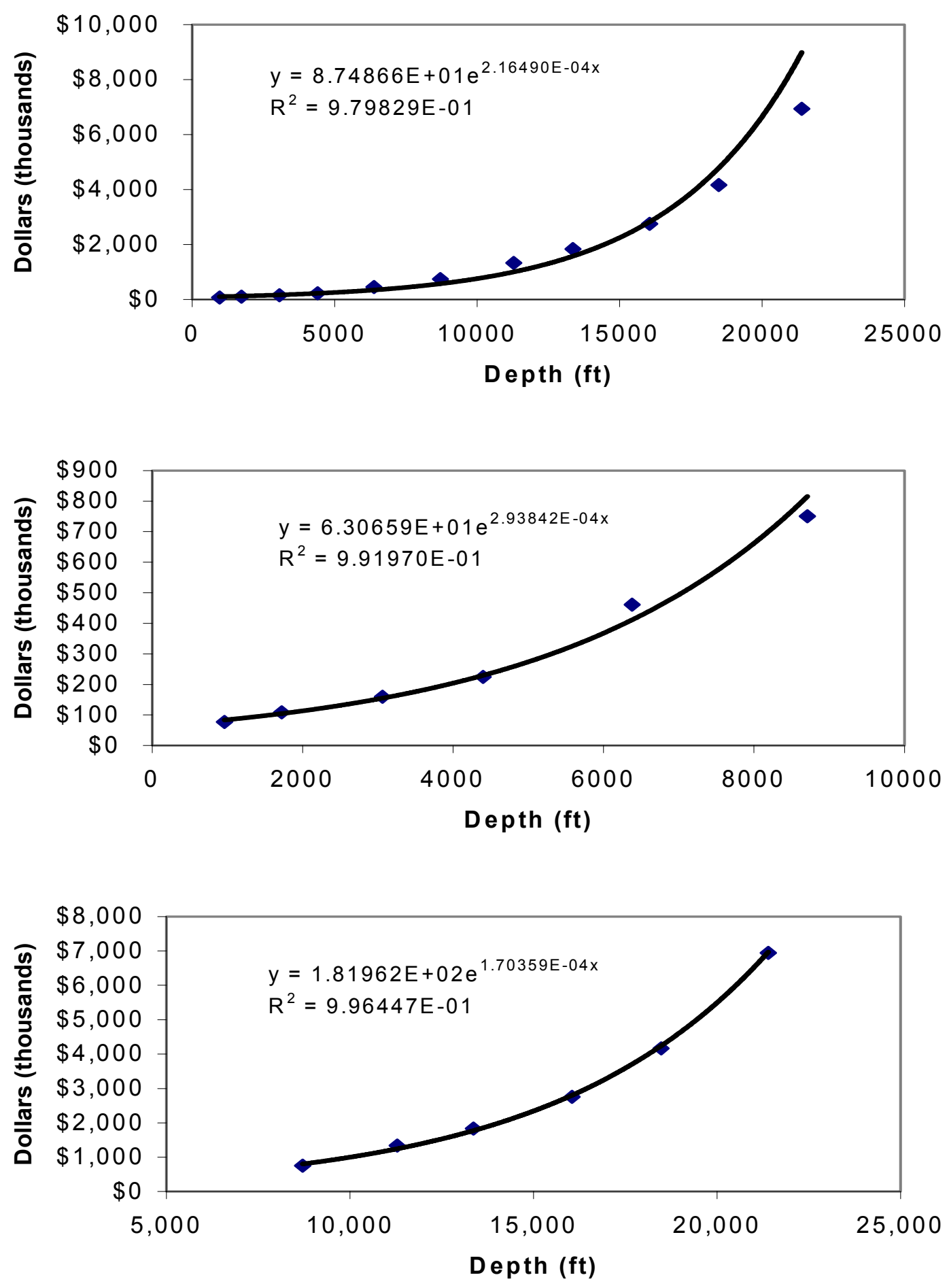


\section{Power Series Curve Fitting Plots}

\section{Power Series Curve Fit for All Wells Surveyed}
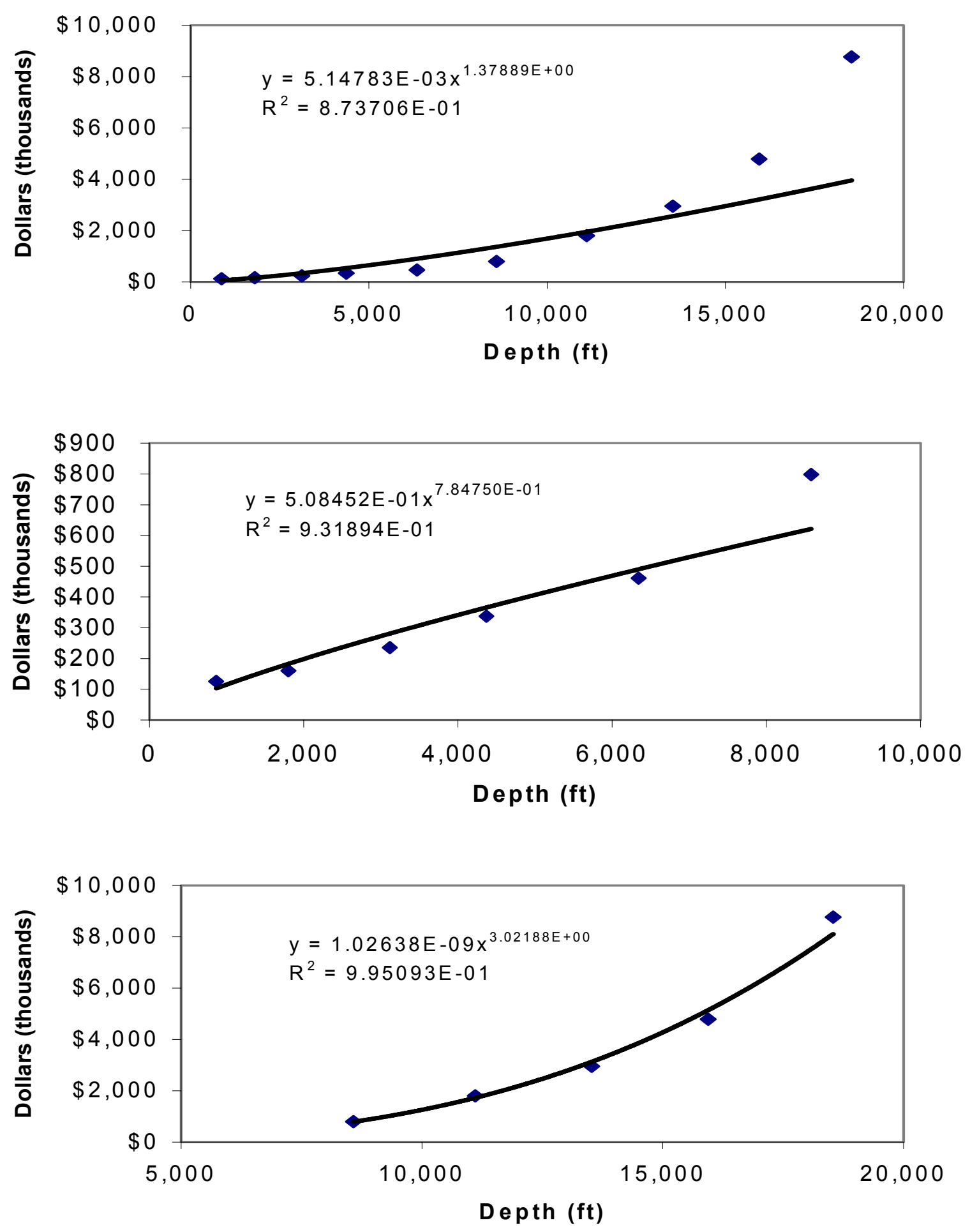


\section{Western States}

\section{California onshore}
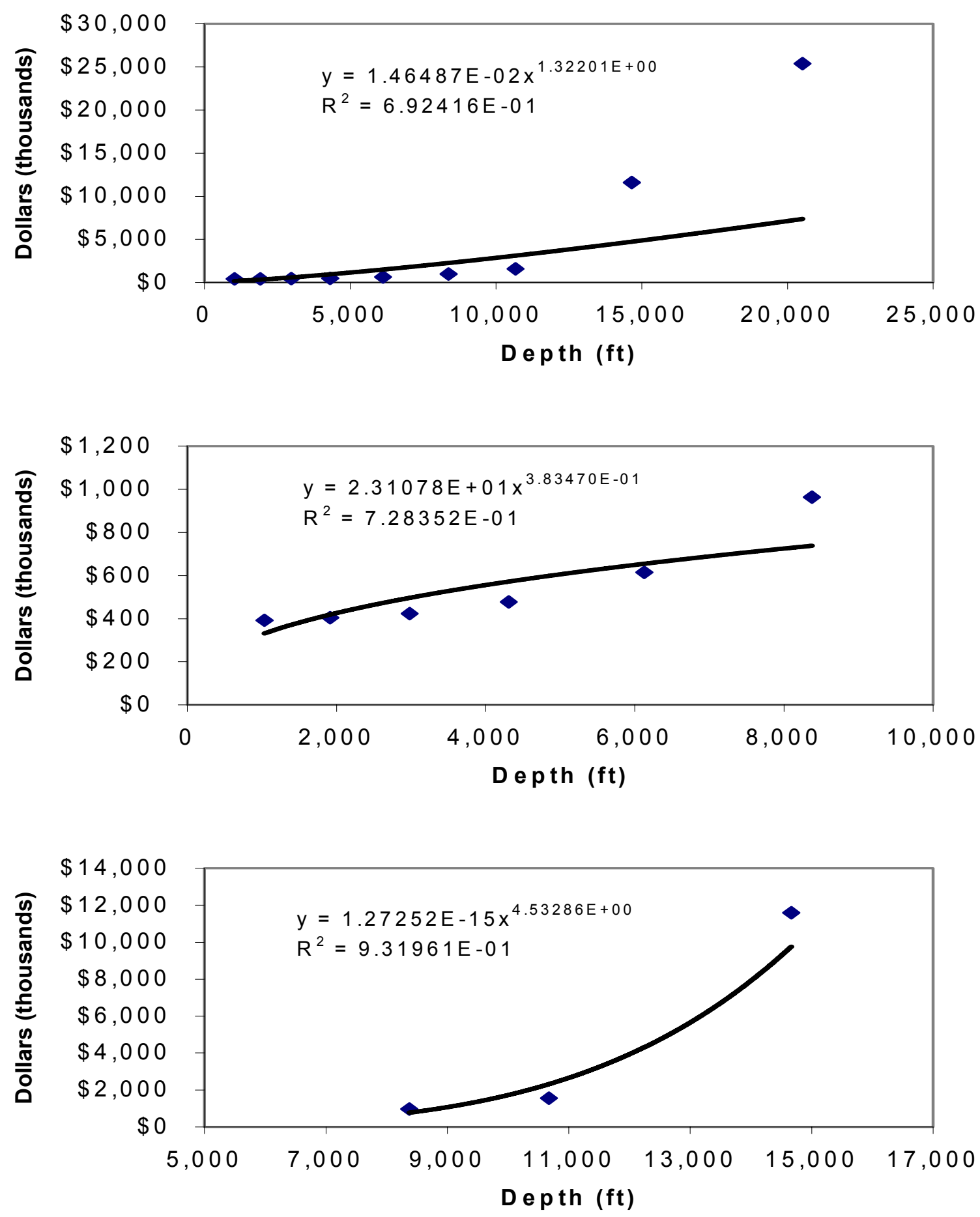


\section{Colorado}
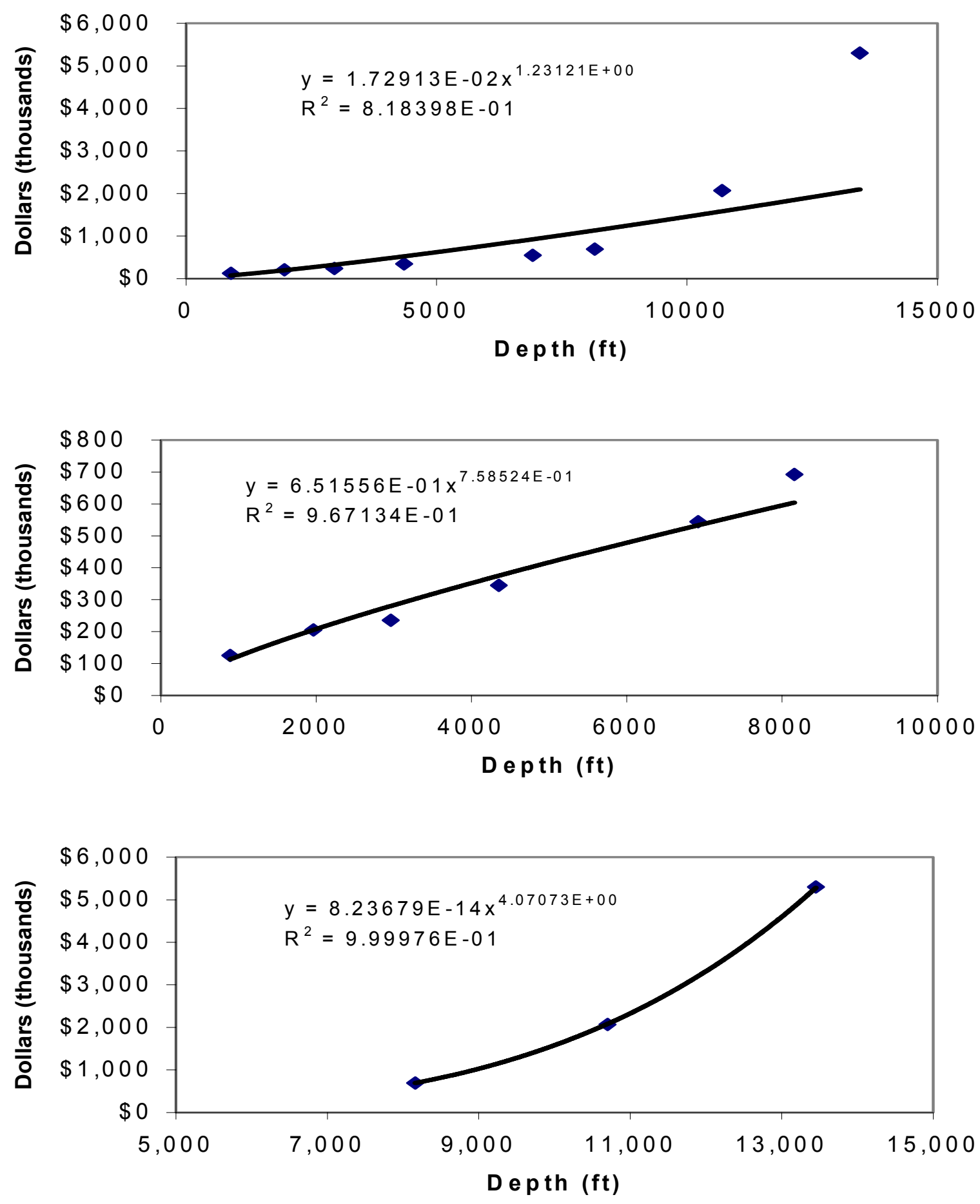


\section{Montana}
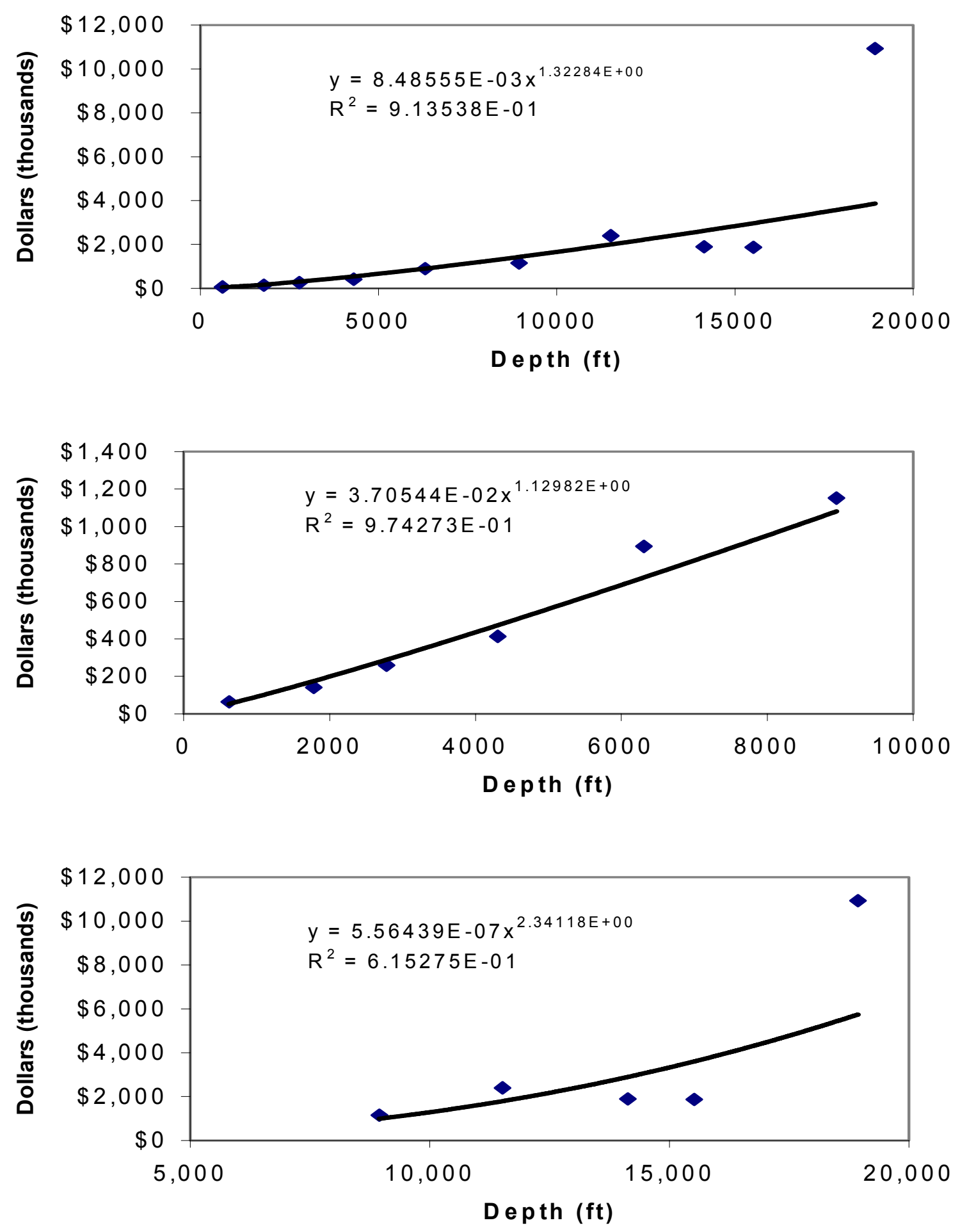
New Mexico
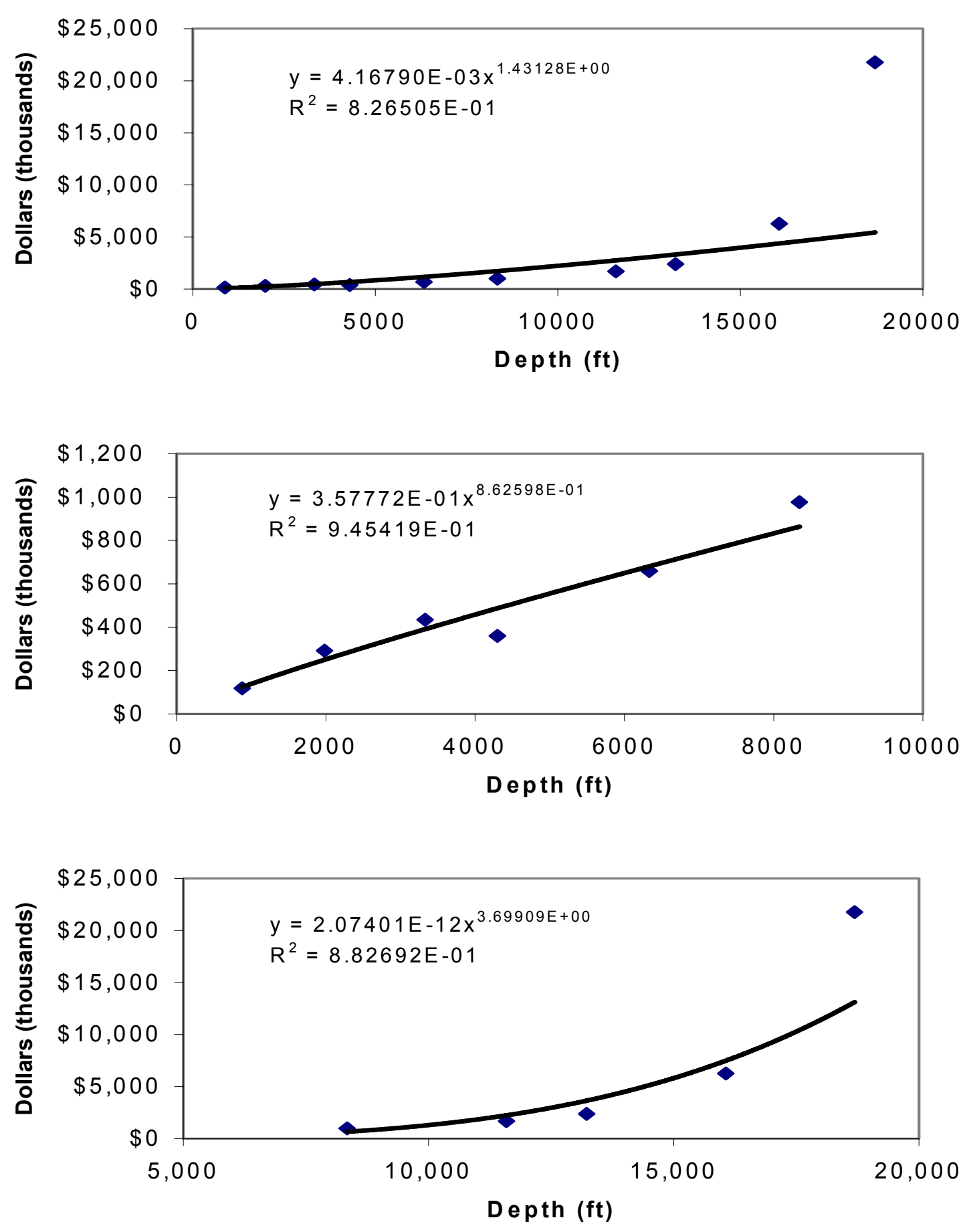


\section{Texas District 8}
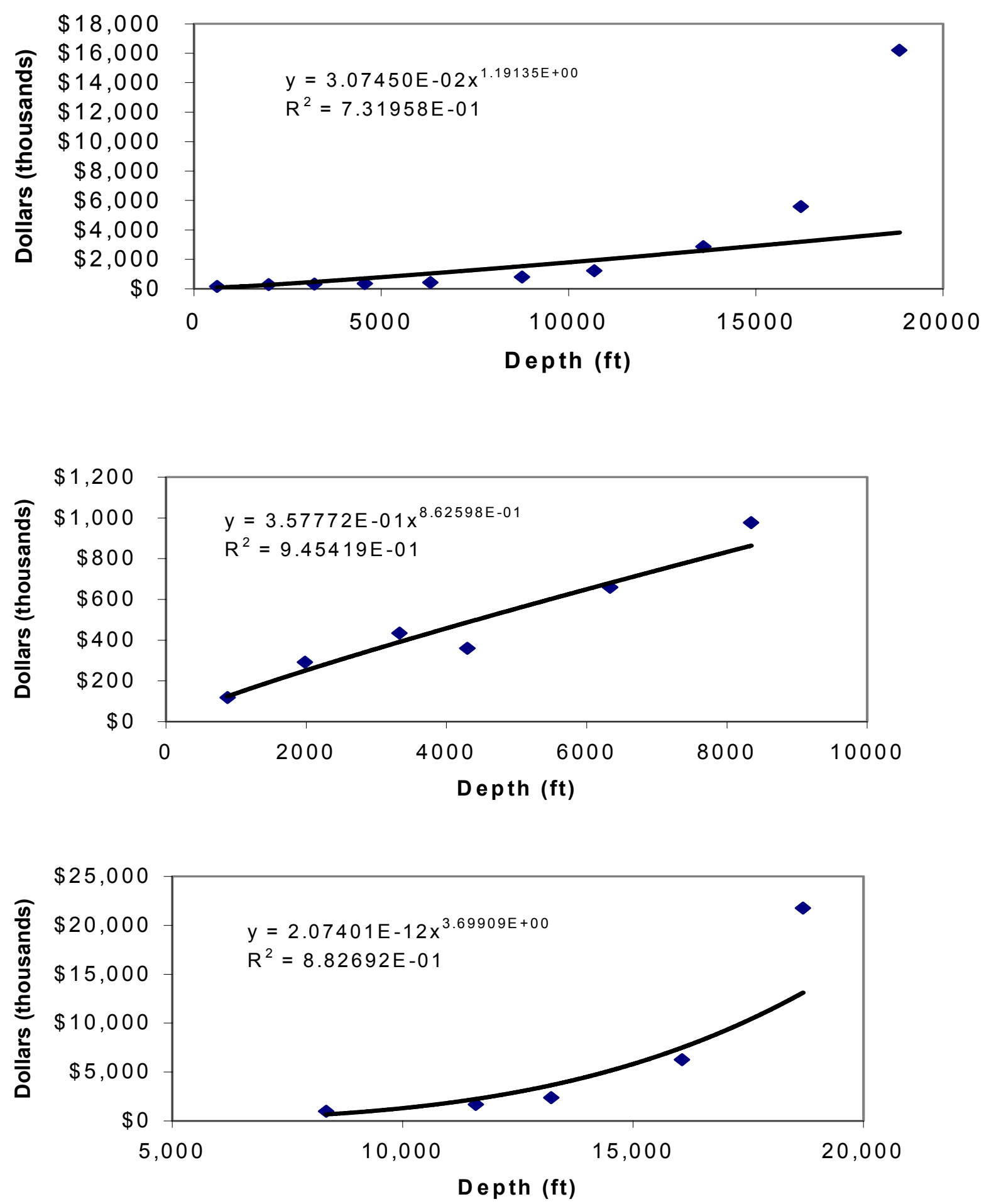


\section{Texas District 8A}
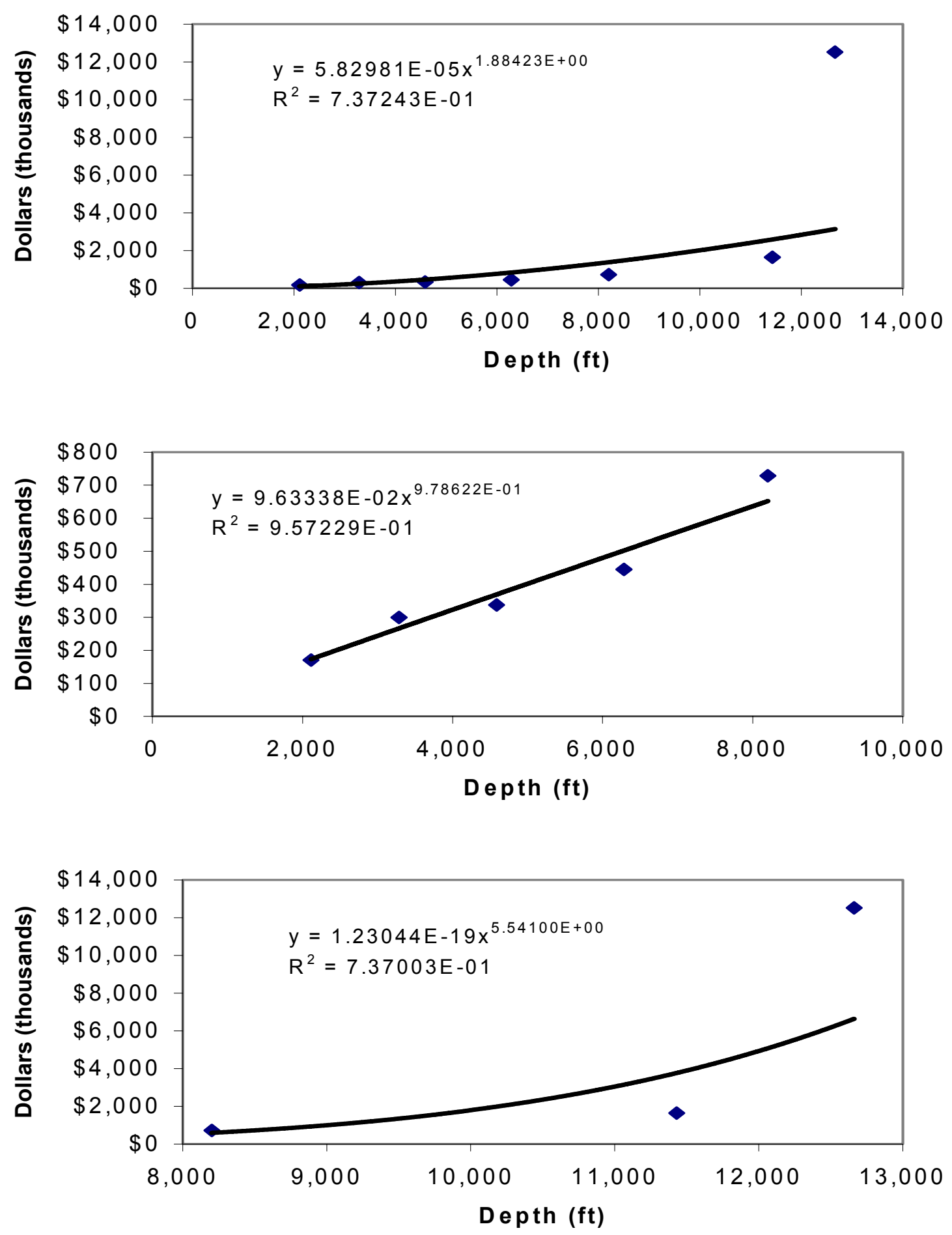


\section{Utah}
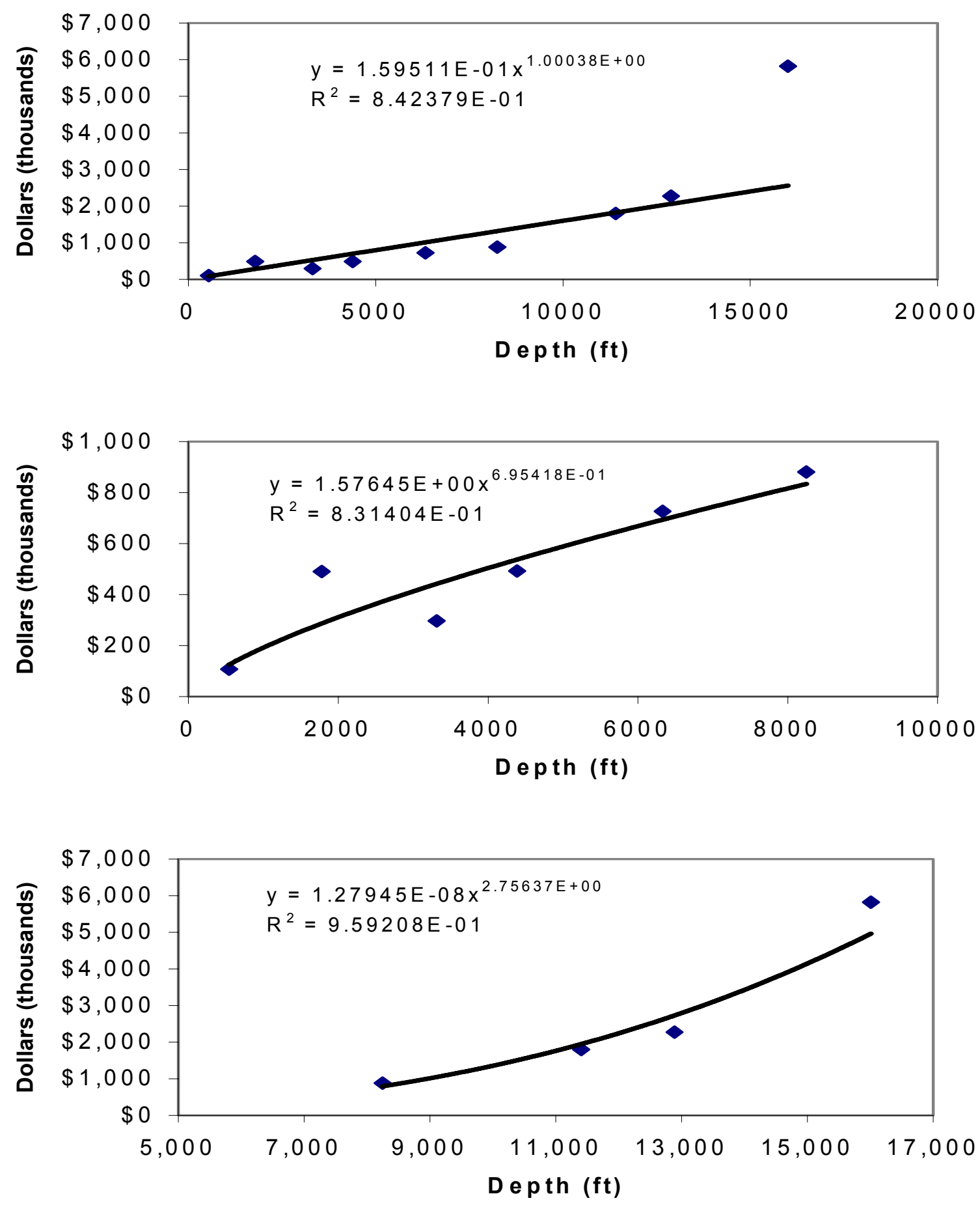


\section{Wyoming}
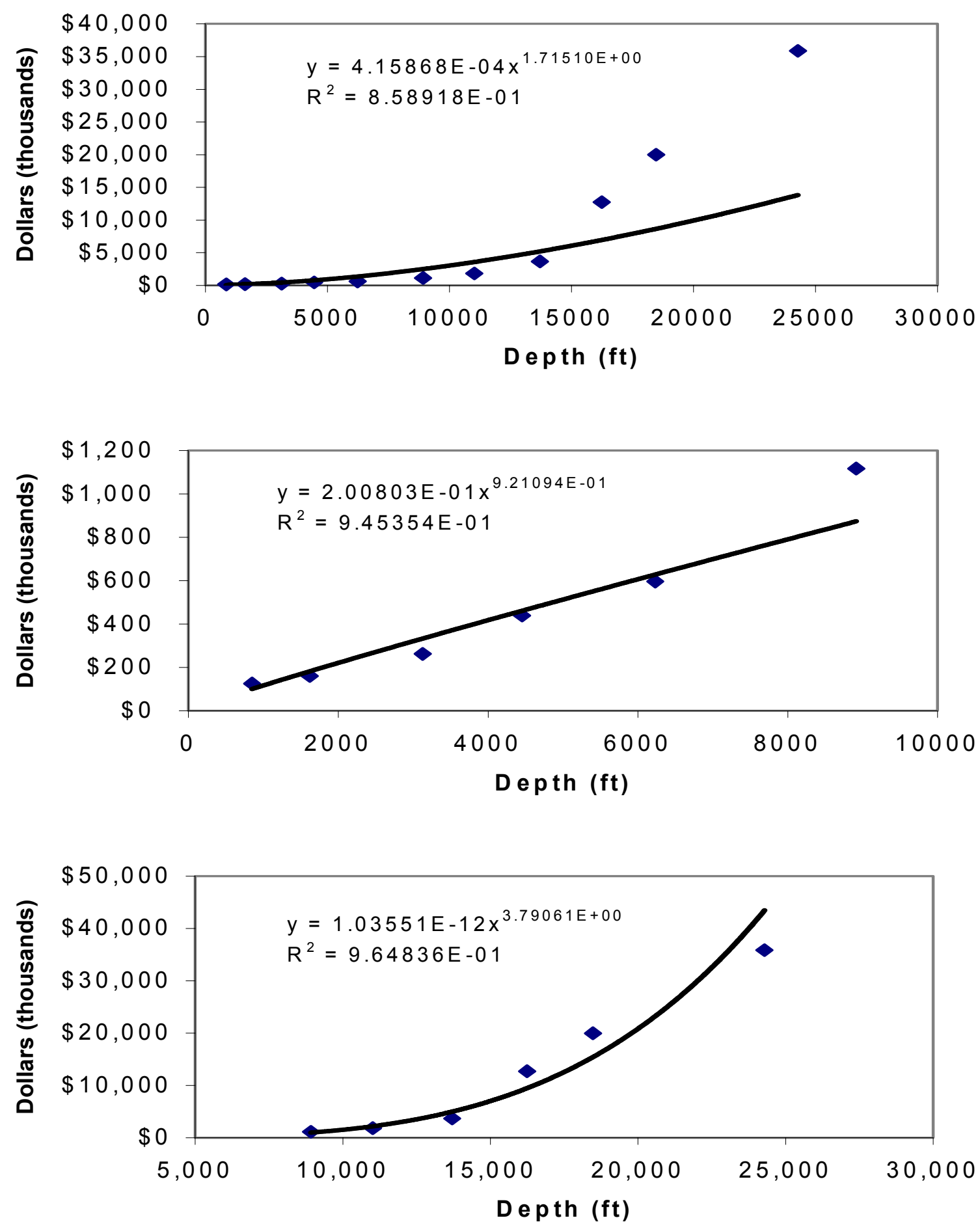


\section{Western U.S States total wells surveyed}
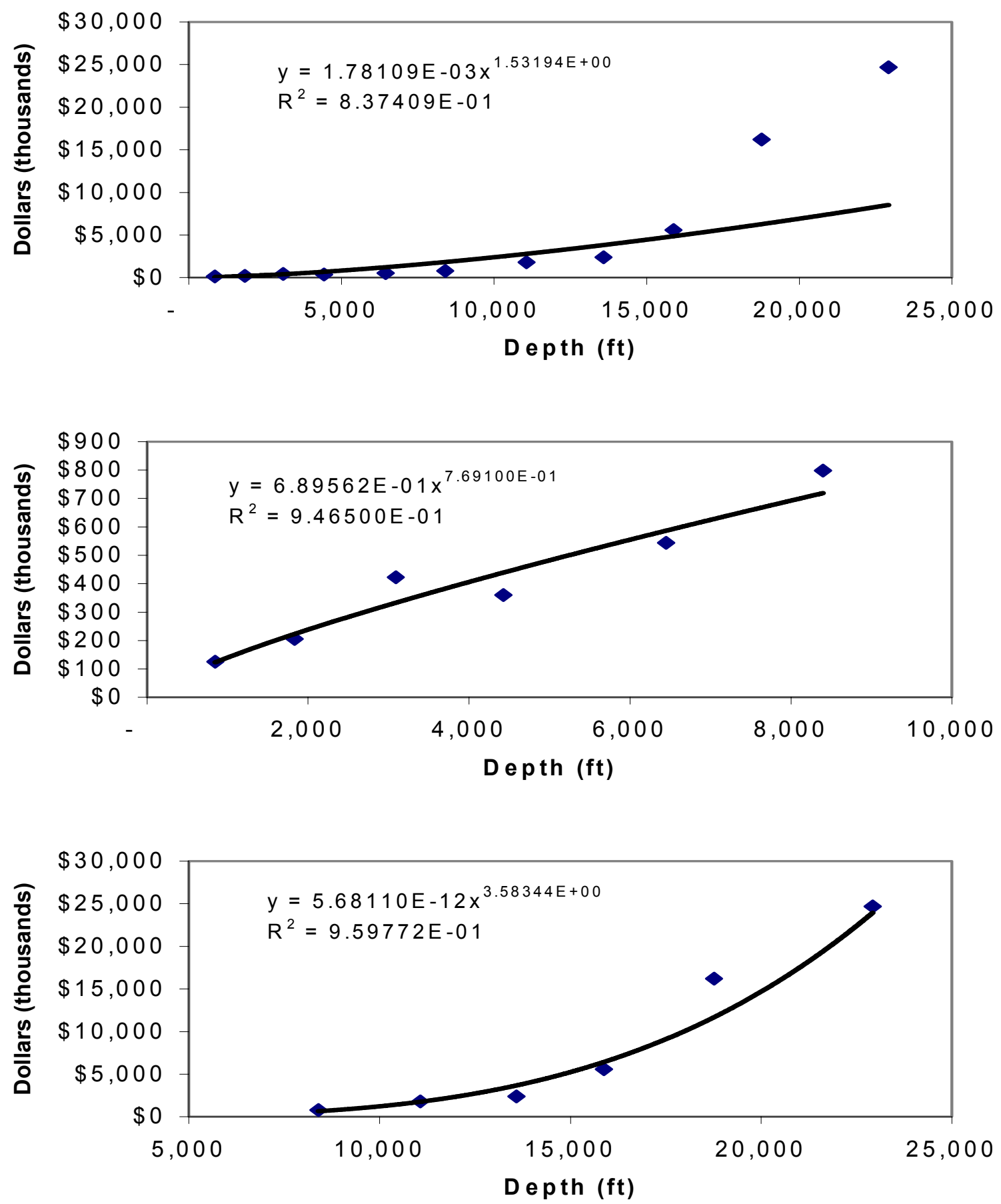


\section{Southeast United States}

\section{Texas Districts 2, 3 and 4}
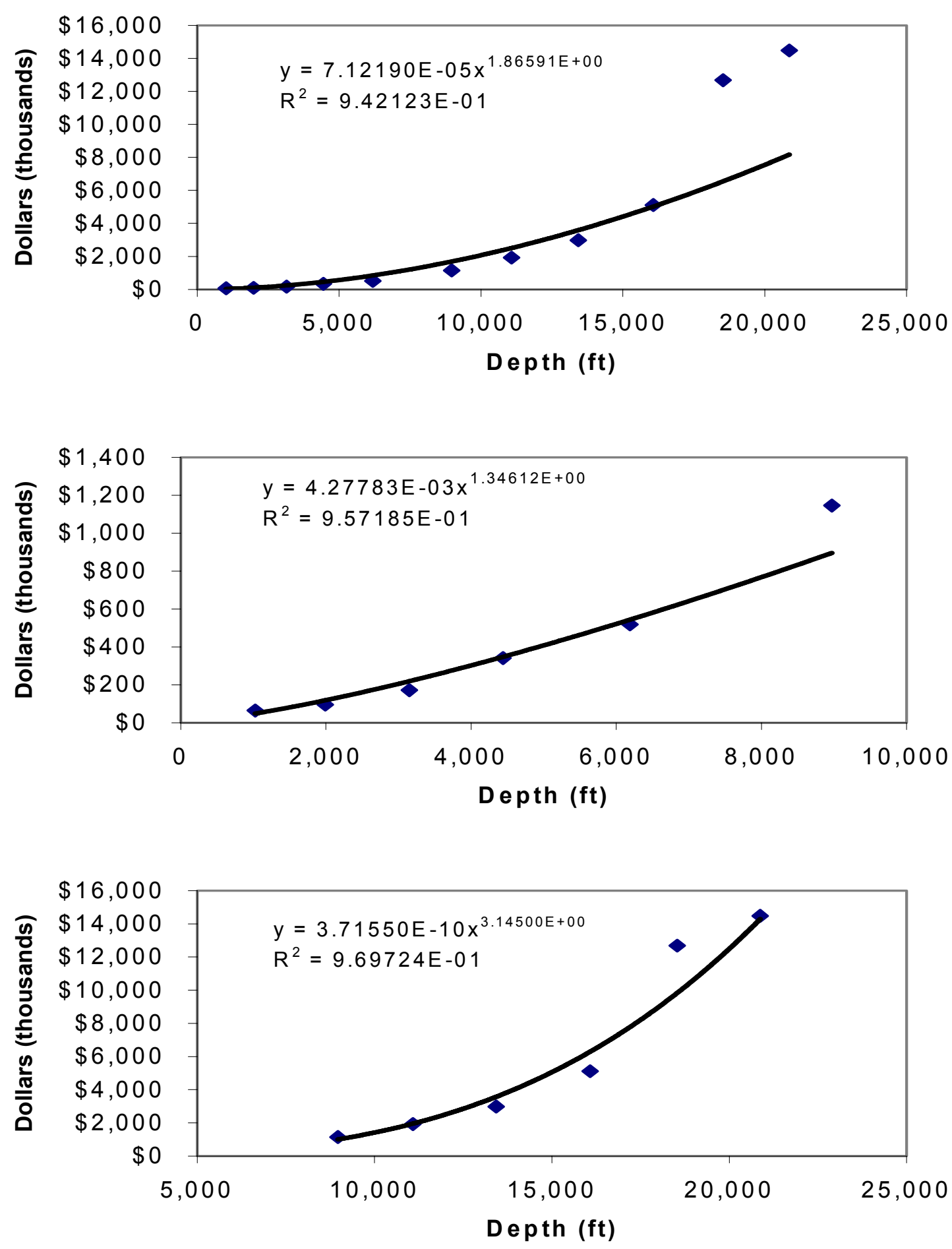


\section{North Louisiana}
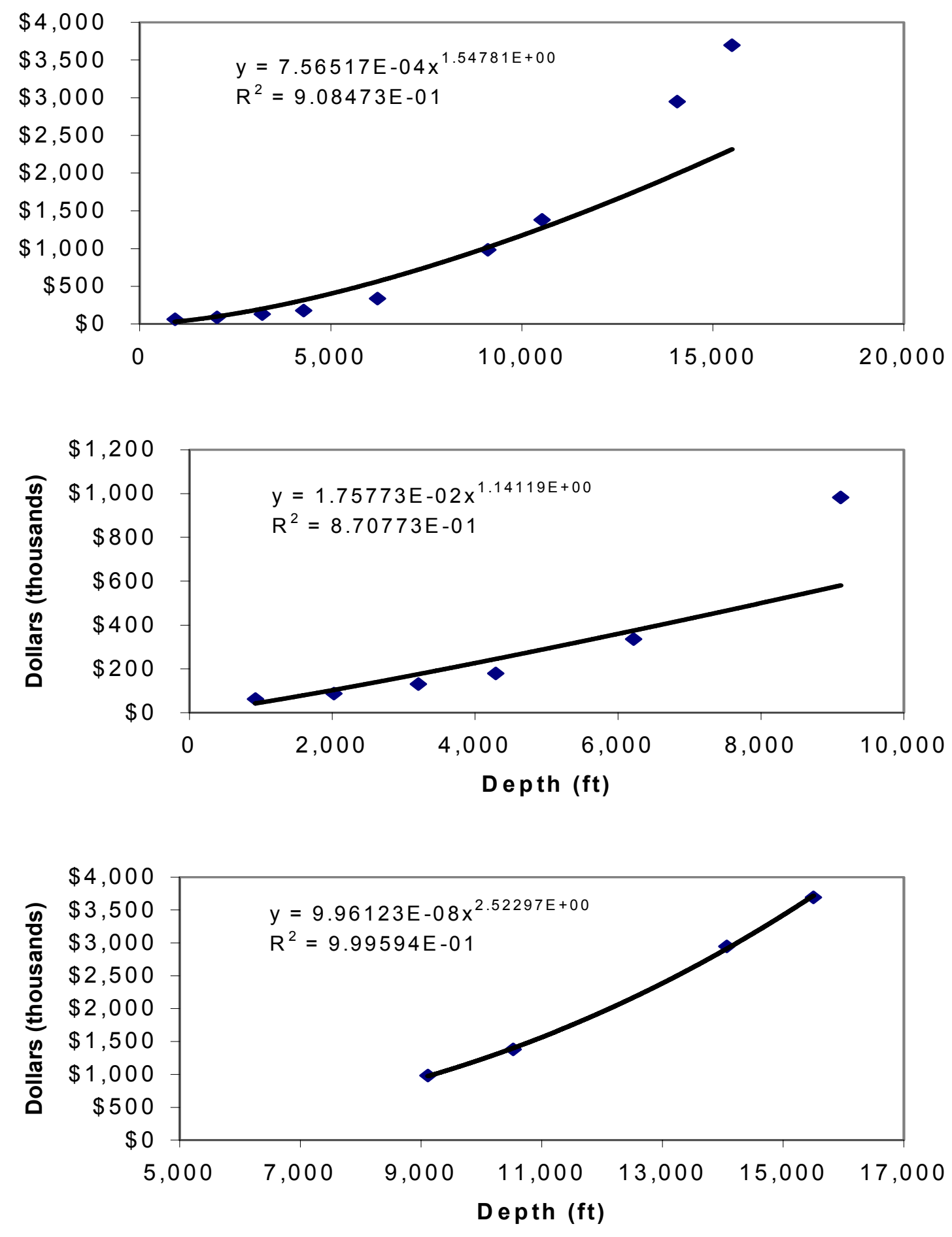


\section{Arkansas}
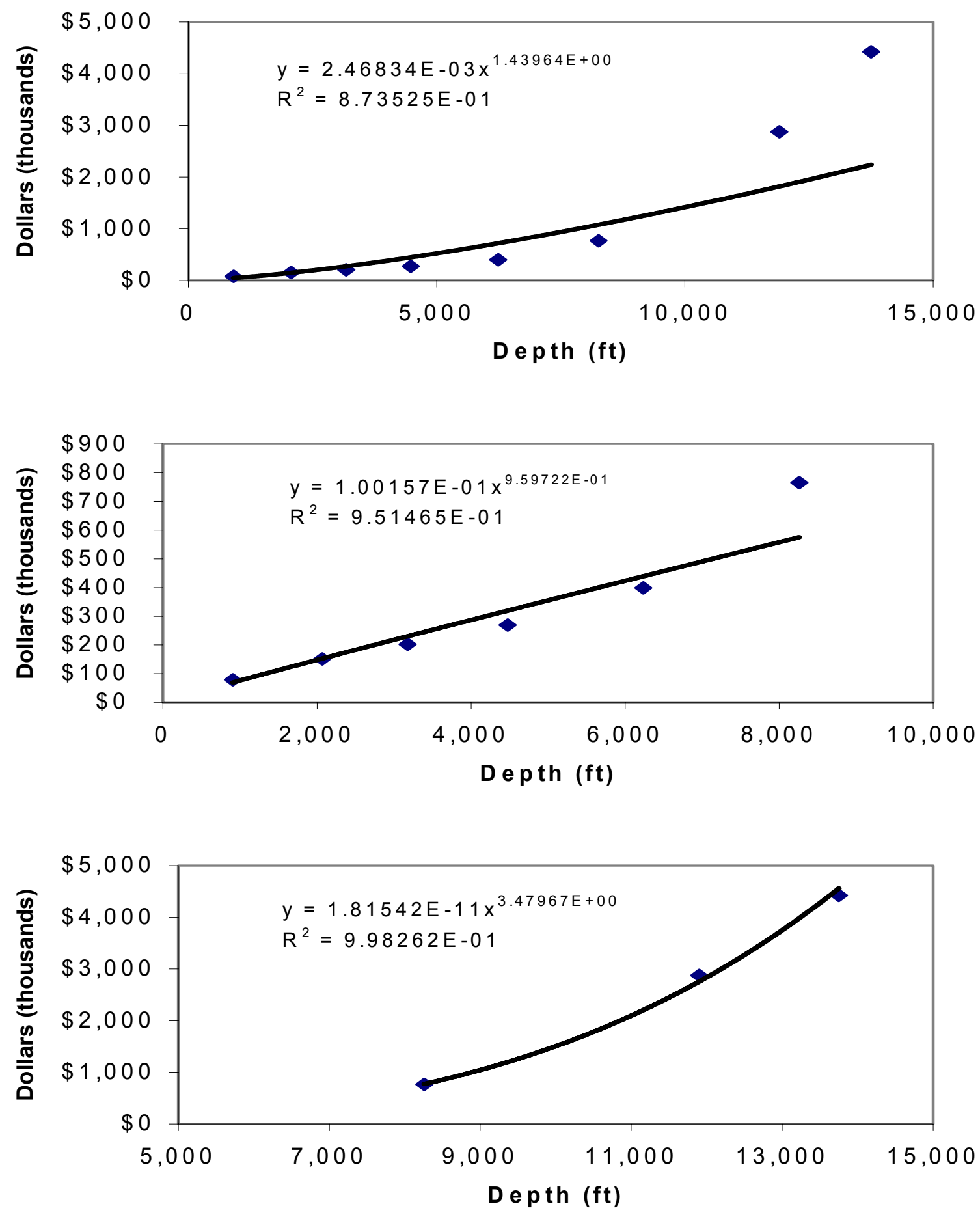


\section{Total wells surveyed Southeast U. S.}
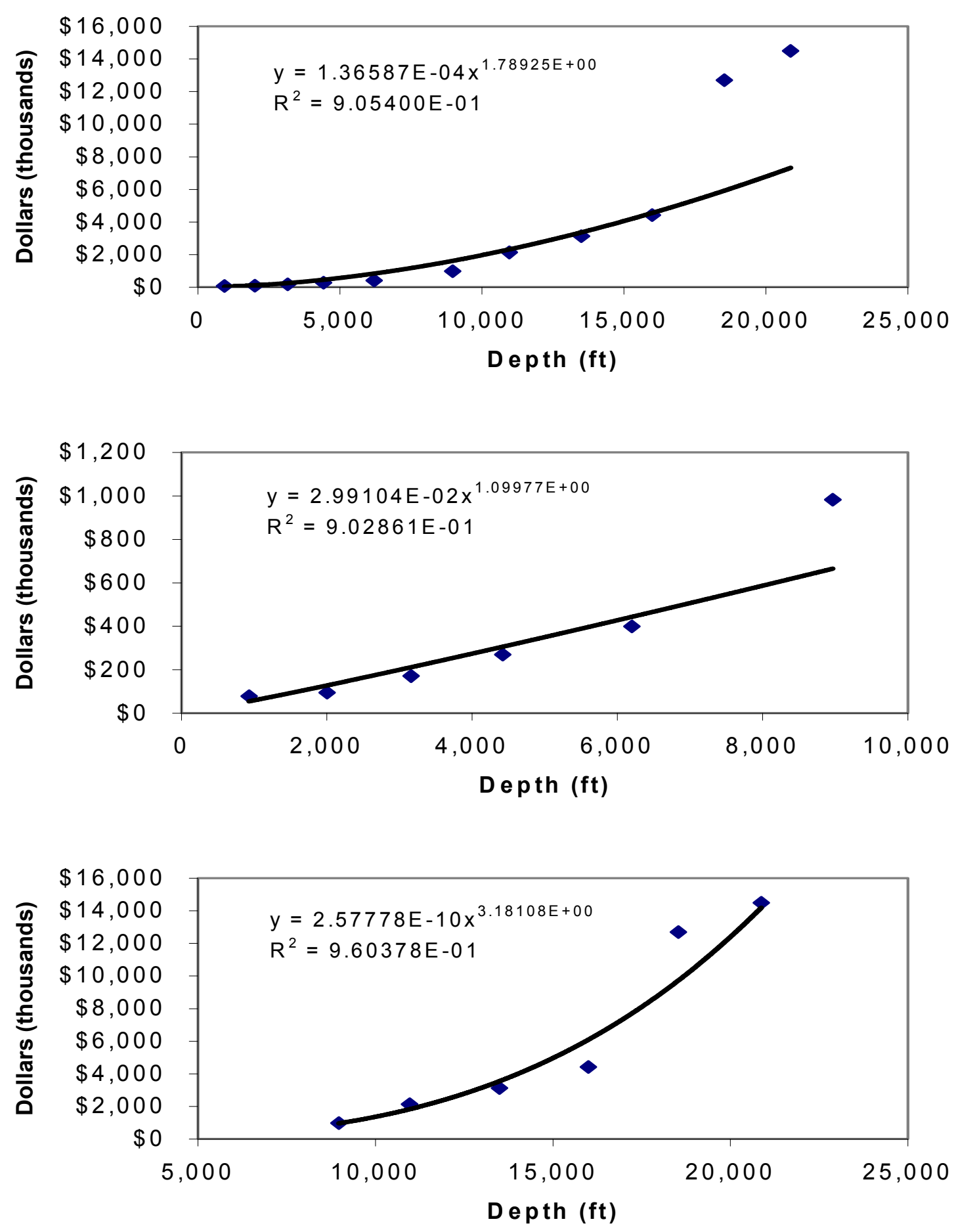
Total wells surveyed Western and Southeast U.S.
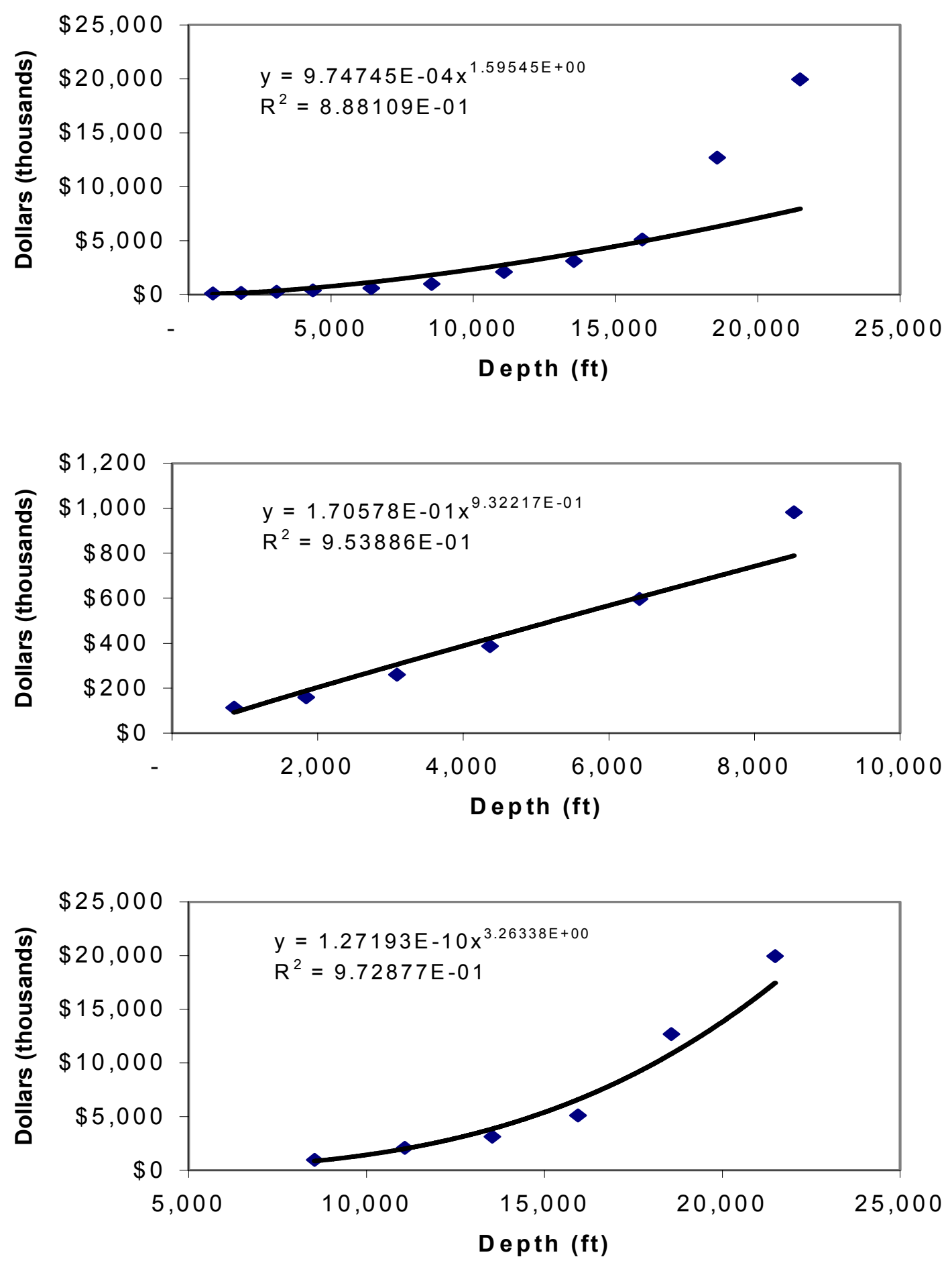


\section{Kansas}

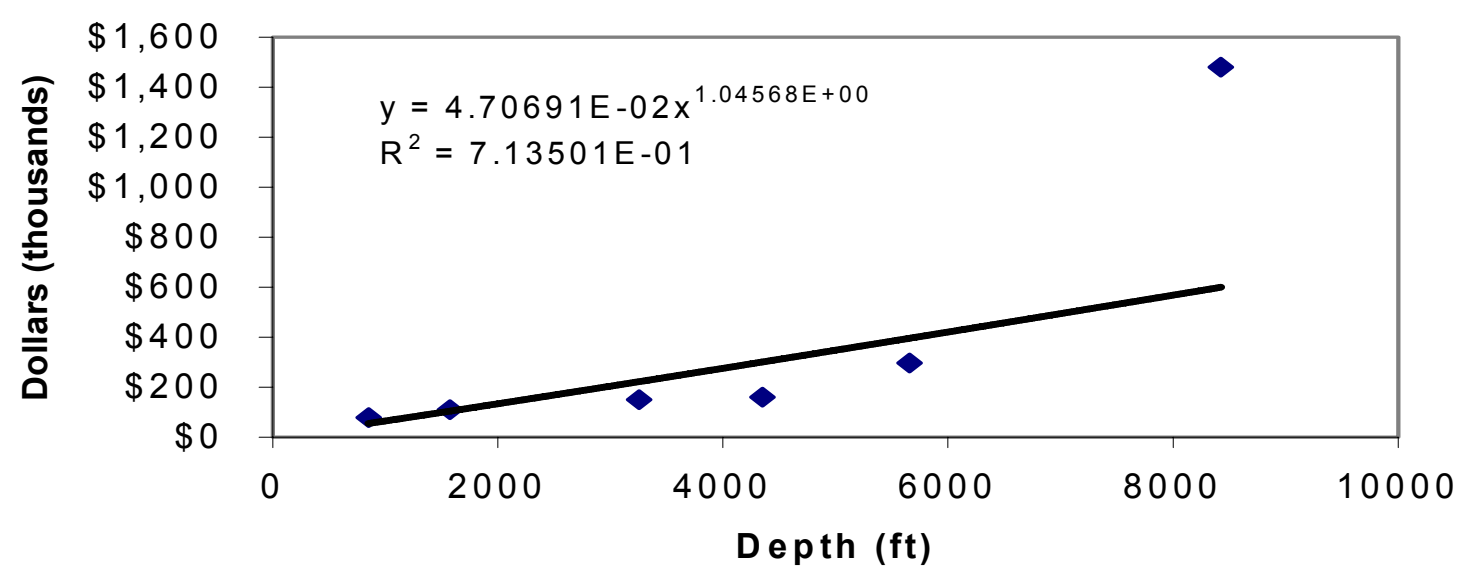

North Dakota

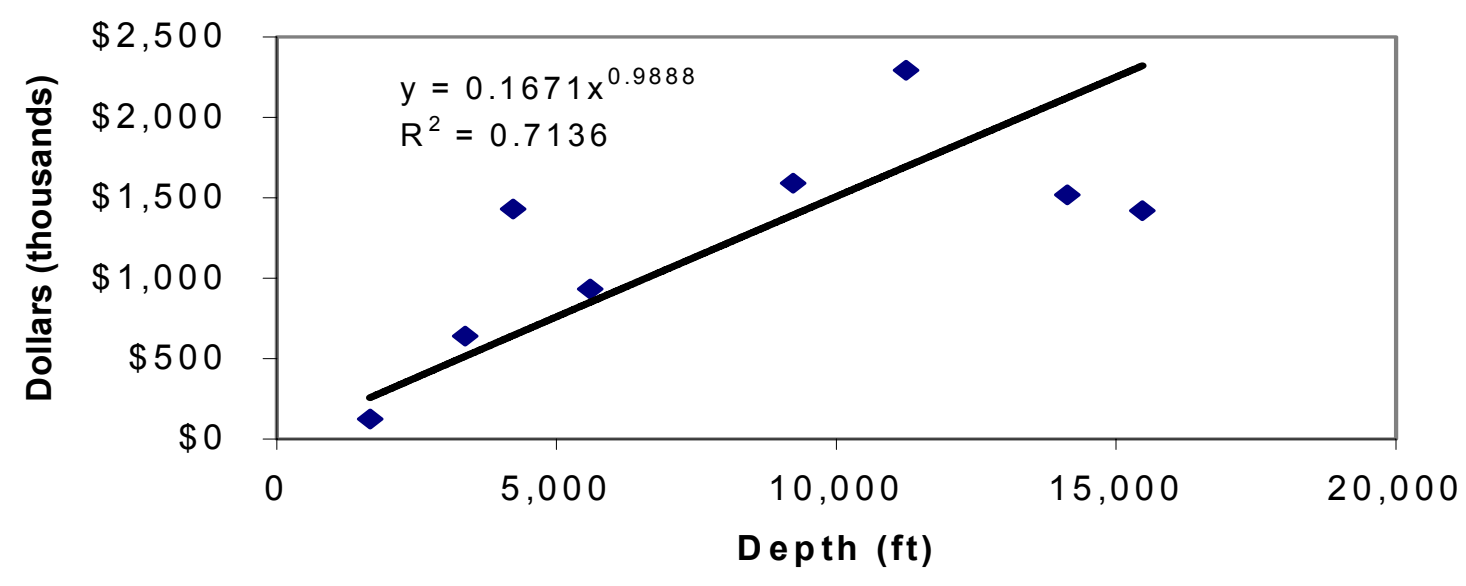




\section{Oklahoma}
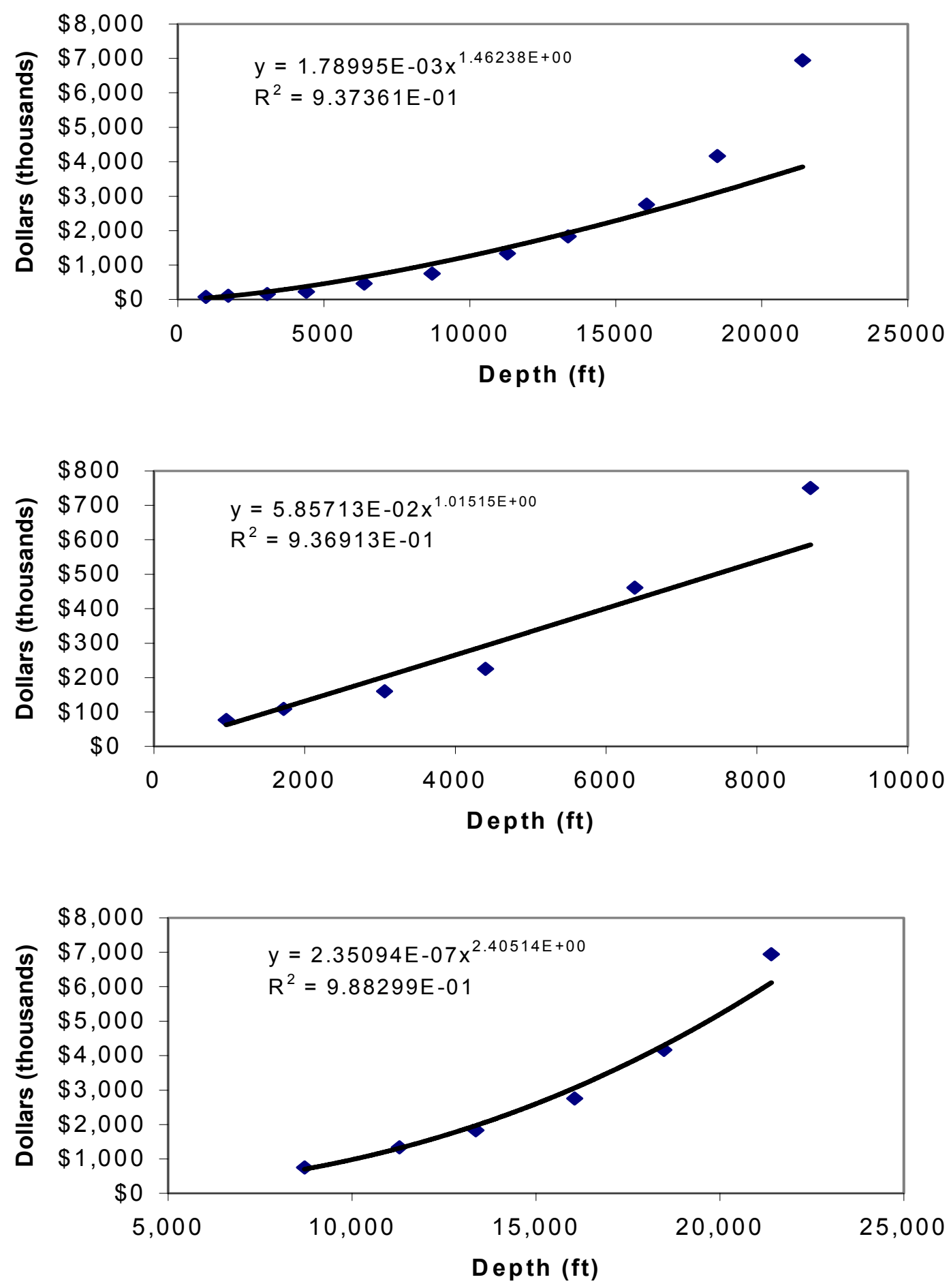